\title{
A DROSOPHILA SPEKTRAPLAKIN SZEREPE HÁMZÁRÓDÁSI FOLYAMATOKBAN
}

\author{
Ph.D. értekezés
}

Készítette: Takács Zsanett

Témavezető: Dr. Jankovics Ferenc

Szegedi Biológiai Kutatóközpont

Genetikai Intézet

Szegedi Tudományegyetem

Természettudományi és Informatikai Kar

Biológia Doktori Iskola

Szeged

2020 


\section{TARTALOMJEGYZÉK}

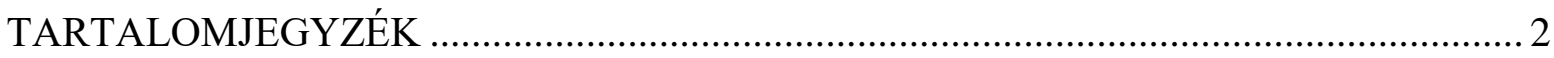

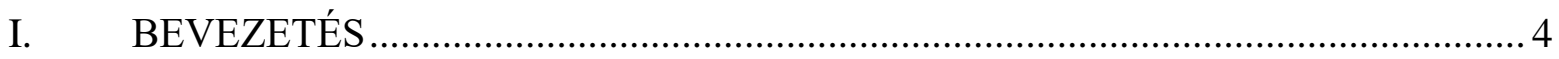

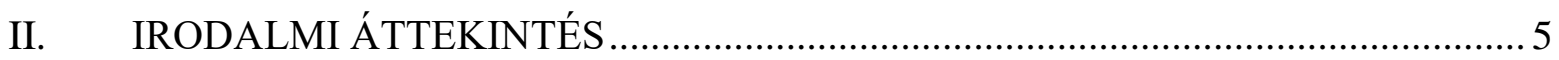

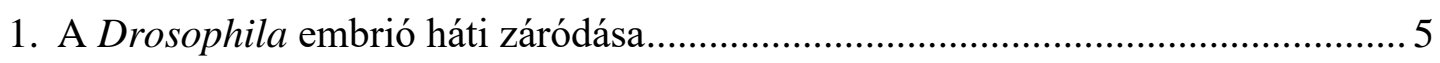

2. A sejtváz és szerepe a háti záródásban........................................................... 9

2.1. A sejtváz általános jelelmzői ............................................................... 9

2.2. A sejtváz müködése a háti záródás alatt .................................................... 13

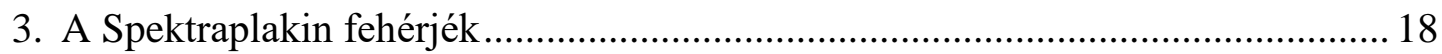

3.1. A Spektraplakin fehérjék jelentősége ...................................................... 18

3.2. A Spektraplakin fehérjék szerkezete..................................................... 20

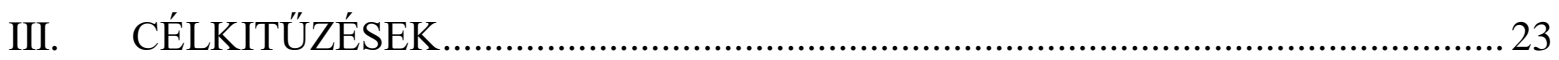

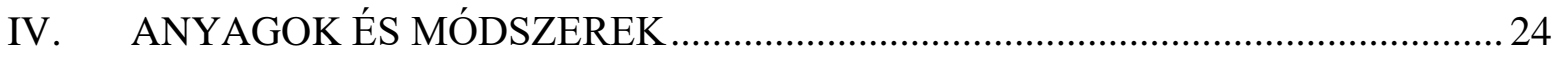

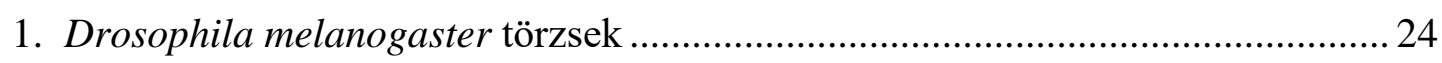

2. Shot ${ }^{\triangle E G C}$ mutáns allél létrehozása CRISPR/Cas9 módszerrel............................... 26

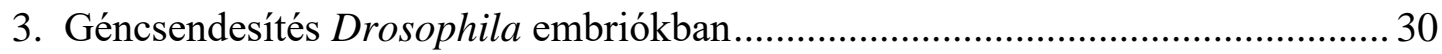

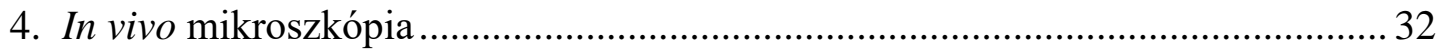

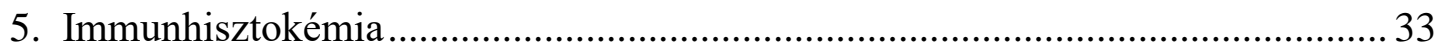

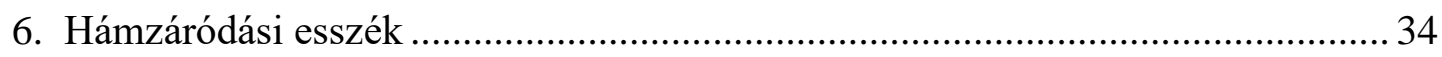

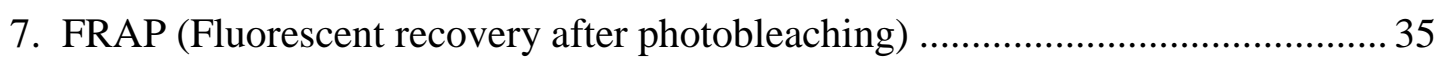

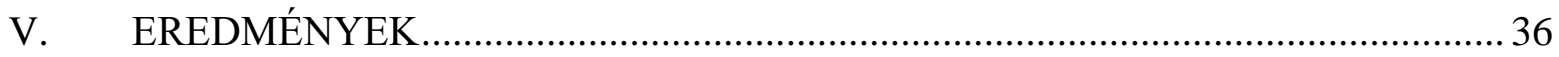

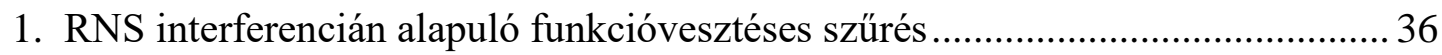

2. Shot ${ }^{A E G C}$ mutáns allél létrehozása CRISPR/Cas9 módszerrel.............................. 40

3. A Shot fehérje aktin-MT keresztkötő aktivitásával szabályozza a cipzározódást . 43

4. A Shot fehérje a hámsejtek MT-vázának elrendeződését szabályozza.................. 45

5. A Shot fehérje a MT-okat stabilizálja ............................................................... 47 
6. A Shot fehérje aktin-MT keresztkötő aktivitása szükséges a MT-ok

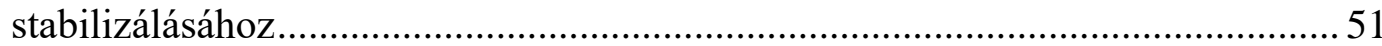

7. A Shot fehérje elősegíti a filopódium képződést a vezető élben ...........................59

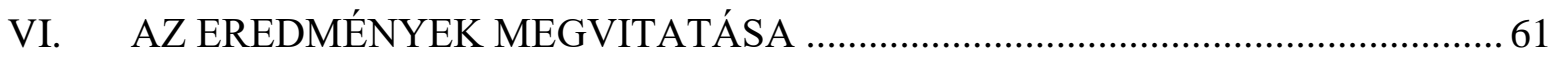

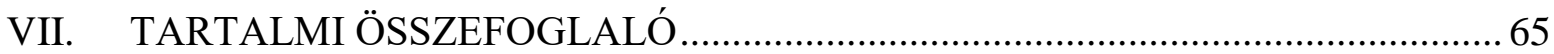

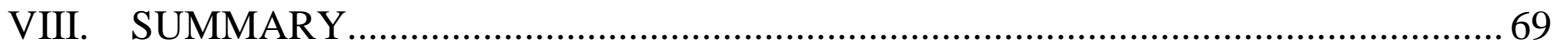

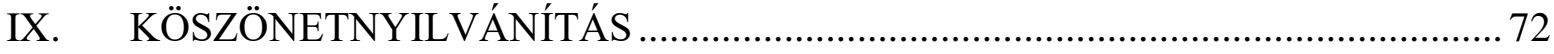

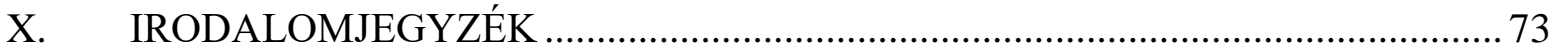

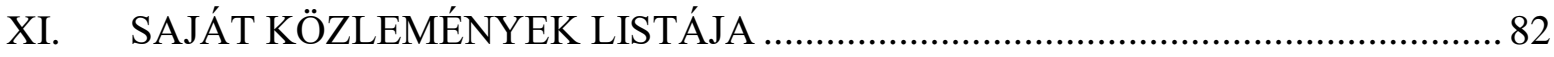




\section{BEVEZETÉS}

Az egyszerủ szövetes élölényektől az emberig a szigorúan rendezett szöveti struktúra fenntartása létfontosságú a túléléshez. Ennek a struktúrának a kialakulása egy komplex, evolúciósan konzervált jelátviteli hálózatok által szabályozott folyamat, mely során lezajló molekuláris, illetve sejt-és szövetszintü változások megegyeznek, függetlenül attól, hogy ez éppen a környezet hatásaival szembeni ellenállást (pl. sebzáródás) vagy a fejlödéshez szükséges változásokat jelenti [1].

Az ember egyedfejlődése során a sejtek csoportos vándorlása majd összekapcsolódása alapjául szolgál olyan, a fejlődés szempontjából kritikus folyamatoknak, mint az agy, a gerincvelö, a koponyaüregek vagy az ivarszervek kialakulása. Az egyedfejlődés során számos esetben, például a szájpadlás vagy az állkapocs kialakulása alatt, a test két oldalán létrejött szövetek a középvonal felé mozognak, és ott látható nyom nélkül olvadnak össze. Ezekben a szigorúan szabályozott folyamatokban bekövetkezett hibák olyan fejlődési rendellenességekhez vezethetnek, mint a nyitott gerinc vagy a farkastorok [2]. Az embrionális fejlődés során történő szövetösszenövésekhez hasonló folyamatok mennek végbe a természetes módon vagy sebzés hatására létrejött hámhiányosságok bezárásakor is [3, 4]. A hámzáródási folyamatok alapvető mechanizmusainak mélyebb megértése, a benne részt vevő molekulák felderítése és vizsgálata éppen ezért hosszú távon felgyorsíthatják a sebgyógyulást elősegítő újszerü eljárások kifejlesztését. Kutatásainkkal végső soron azokat a stratégiákat szeretnénk megismerni és megérteni, amiket az élőlények alkalmaznak a hámnyílások bezárásához. Az ecetmuslica (Drosophila melanogaster) embriójának háti záródása alkalmas modellt kínál e jelenségek genetikai és sejtbiológiai vizsgálatához, ugyanis az ecetmuslica egyedfejlődése során az embrió hátán egy nyílás alakul ki, amit a két oldalsó hámlemez a háti középvonal mentén bezár. A háti záródást kísérő molekuláris, illetve sejt-és szövetszintű változások evolúciósan konzerváltak, megegyeznek és közösek az egész állatvilágban.

A Drosophila genetika kiforrott eszköztára, a nagyszámú mutáns allél, a transzgének elérhetősége és az in vivo videomikroszkópia egyszerü és gyors kutatómunkát tesz lehetővé a bonyolultabb és költségesebb gerinces modellállatokhoz képest. A háti záródás genetikai hátterének vizsgálata azonban túlmutat a háti záródás alapjelenségének megismerésén, hiszen ezen összetett folyamat vizsgálata hozzásegíthet olyan általános fejlődésbiológiai jelenségek pontosabb megértéséhez, mint pl. a sejtalak megváltozásához szükséges sejtváz átrendeződés. 


\section{IRODALMI ÁTTEKINTÉS}

\section{A Drosophila embrió háti záródása}

A Drosophila embrió háti záródása az embrionális fejlödés 12-16. stádiuma között, a pete lerakásától számított 10-12. órában zajlik. A háti záródás az embriófejlődés utolsó morfogenetikai mozgása, melynek során két egyrétegű hámlemez mozog egymás felé, majd találkoznak és összeolvadnak, ezáltal bezárva egy nyílást a háti középvonal mentén. A háti záródás négy egymást részben átfedő folyamat sorozatából áll (1. ábra). A záródás első fázisa az iníciáció, ami az embrió megrövidülésének (germ band retraction) befejezését megelőzően kezdődik, amikor a csírasáv visszahúzódik a fejlődő embrió poszterior részére, így az embrió hátán egy ellipszis alakú lyuk jön létre (1. ábra A). A háti nyílást egy átmeneti, extraembrionális szövet, az amnioszeróza (AS) védi a két oldalsó egyrétegü hámlemez között. A második fázis a hám kiterjedése (1. ábra B). Az AS és a hám határán elhelyezkedő hámsejtek (DME, dorsal most epithelial) egy sorba rendeződnek és kialakul egy vezető él. A DME sejtek kiemelt fontosságúak a háti záródás szempontjából. Az iniciáció során ezek a sejtek reagálnak a záródást elindító jelmolekulákra, majd hajtják végre a záródást és végül közöttük alakulnak ki a háti nyílást bezáró sejtkapcsolatok. A DME sejtek aktint és miozint halmoznak fel az AS felé eső oldalukon, ezáltal kialakul egy szupracelluláris aktomiozin gyürü, ami a háti lyukat körülveszi. A záródás második fázisában a hámlemezek egymás felé közelítenek. Ekkor a DME sejtek, majd a DME sejtektől ventrális irányban elhelyezkedő hámsejtek megnyúlnak a dorzoventrális tengely mentén. Amikor a hámsejtek a háti nyílás két végén összeérnek, elkezdődik a harmadik fázis („cipzározódás”), amely során az ellenkező irányból érkező hámlemezek összekapcsolódnak (1. ábra C). Ekkor a DME sejtek dorzális felszínén aktinalapú sejtnyúlványok - filopódiumok és lamellipódiumok- jelennek meg, amelyek az új sejtkapcsolatok szegment specifikus kialakulását biztosítják a szemben lévő hámsejtek között. Mikor a hámsejtek elég közel vannak egymáshoz, a sejtek tetőcserépszerüen átlapolódnak. Az átlapolódások a cipzározódás végére megrövidülnek és a hámsejtekre jellemző sejt-sejt interakciós felületekké alakulnak át. Az utolsó, terminációs fázisban az összekapcsolódó hámlemezek mozgása megszünik, az aktin alapú szerkezetek is szétszerelődnek a sejtek között pedig stabil kapcsolatok alakulnak ki (1. ábra D) [5-10]. 

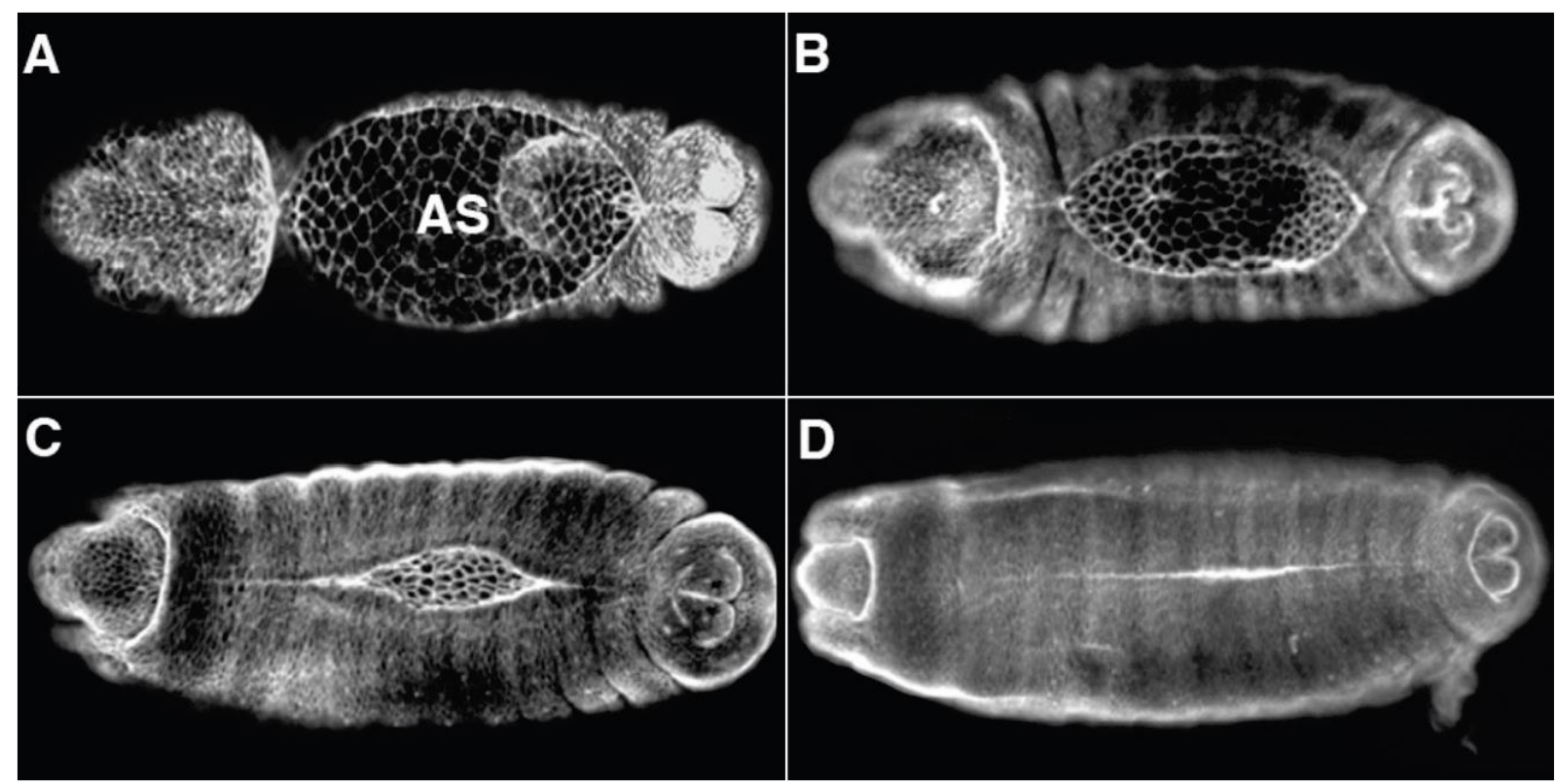

1. ábra. A Drosophila embrió háti záródása. (A-D) Konfokális fluoreszcens felvételek a háti záródás folyamatáról. Az embrió balról jobbra anterior poszterior irányban látható [11].

A háti záródást kísérő morfogenetikai változásokat mechanikai erők vezérlik, melyek összehangolt kölcsönhatása nélkülözhetetlen a háti záródás különböző szakaszaiban (2. ábra A). Az AS sejtek pulzáló összehúzódása egymásfelé húzza a hám két szélét, ezáltal elősegíti a hámlemezek előremozdulását [12]. A záródás végére ezek a sejtek a hám alá kerülnek és apoptózissal elpusztulnak. További húzóerő van jelen a vezető él mentén, melyet a háti nyílás körül kialakuló supracellularis aktomiozin gyürü generál [12, 13]. Az aktomiozin gyürü hatására kiegyenesedik a háti záródás mozgási frontja és a hámlemezek cipzárként olvadnak össze az embrió háti középvonala mentén. További, ellentétes irányú erőt biztosítanak a laterális hámlemezekben jelentkező feszültség és az AS sejtek intracellulásris nyomása, melyek ellenállnak a záródást segítő többi erőnek, hogy fenntartsák az egyensúlyt a sejtalakváltozások és a szövetek mozgása között (2. ábra A) [14, 15].

Az egyes erőhatások hozzájárulása a háti záródáshoz nem azonos. Hutson és munkatársai áttörő tanulmányukban lézer indukálta sérülések sorozatát végezték el a háti záródás különböző stádiumaiban, hogy felmérjék ezen erőhatások szerepét a folyamatban [13]. Ez lehetővé tette egy olyan matematikai modell kifejlesztését, mely a háti záródás alakváltozását írja le és alkalmas a vad típusú, de a mechanikailag sérült vagy genetikailag mutáns embriók háti záródásának számszerüsítésére egyaránt. 
A

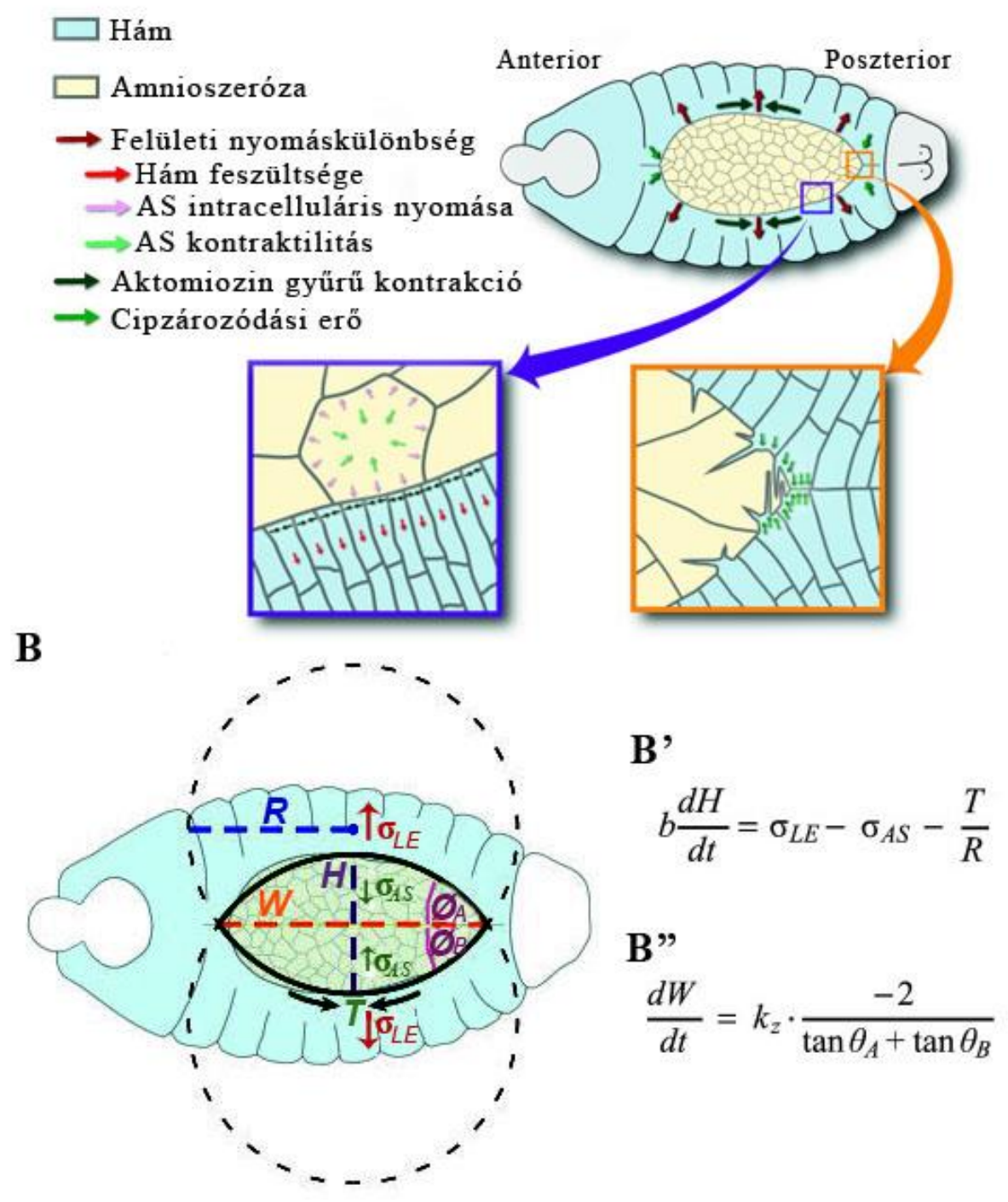

2. ábra. A háti záródásra ható erök és a záródás matematikai modellje Drosophilában. (A) A zöld nyilak a háti záródást segitő erőket, míg a piros nyilak a záródás ellen ható eröket jelölik. A bal alsó kék négyzet az AS kontraktilitást (világos zöld nyilak), AS intracelluláris nyomását (rózsaszín nyilak), az oldalsó hámlemezek húzóerejét (piros nyilak), valamint az aktomiozin gyürü által generált húzóeröt (sötét zöld nyilak) mutatja. A jobb alsó narancssárga négyzet a sejtnyúlványok aktivitását mutatja a cipzározódás alatt. (B) A háti záródás leirásához használt geometriai paraméterek: W, a cipzározódó végek távolsága; $H$ az egymás felé elmozduló hámrétegek távolsága; $\theta_{A}$ és $\theta_{B}$, a háti középvonal és a vezetö él között bezárt szög; $R$, görbületi sugár. A modell a vezetö éleket két egymást metszö körívnek tekinti és így a háti záródás alakváltozása két egyenlettel irható le: (B') A háti záródás sebességét (dH/dt) a záródást elösegitö aktomiozin gyürü által generált erö $(T / R)$ és az AS összehúzódása $(\sigma A S)$, valamint a záródás ellen ható oldalsó hámlemezek húzóereje ( $\sigma L E)$ közti egyensúly határozza meg, $(b)$ súrlódási együttható. (B”) A cipzározódás sebessége (dW/dt) egy empirikusan származtatott zipzározódási sebességi állandó $(k z)$ valamint a háti középvonal és a vezetö él között bezárt szög $\left(\theta_{A}\right.$ és $\theta_{B}$ ) fügvénye (Hayes és munkatársai nyomán módositva) [15]. 
Első lépésként kiszámítható a záródó hám háti középvonal irányába történő elmozdulásának sebessége. A háti záródást in vivo videomikroszkópiával nyomonkövetve belátható, hogy a háti záródás sebessége állandó $(12 \pm 1,5 \mathrm{~nm} / \mathrm{sec}, \mathrm{N}=5)$, tehát a háti záródást hajtó erők: az aktomiozin gyürüből eredő feszültség (T/R), az AS szövet összehúzódása $\left(\sigma_{A S}\right)$, és a hámlemezek által generált feszültség $\left(\sigma_{\mathrm{LE}}\right)$ egyensúlyban vannak és az erők összege állandó (2. ábra B') [13].

A modell a vezető éleket két egymást metsző körívnek tekinti (2. ábra B), és a háti záródás geometriai paramétereinek változását idõfüggõ módon empirikus sebességi egyenlet alkalmazásával írja le (2. ábra B”). Az egyenletben a $\mathrm{H}$ a háti nyílás teljes hosszúsága, $\mathrm{k}_{\mathrm{z}}$ egy sebességi állandó, $\mathrm{W}$ a cipzározódó végek távolsága, $d W / d t$ pedig kizárólag a háti középvonal és a vezető él között bezárt szög függvénye $\left(\theta_{\mathrm{A}}\right.$ és $\left.\theta_{\mathrm{B}}\right)$. Minnél élesebb ez a szög, a $d W / d t$ értéke annál nagyobb, gyorsabb a záródás. Az egyenlet segítségével meghatározható a cipzározódási sebességi állandó $\left(\mathrm{k}_{\mathrm{z}}\right)$. A modell szerint a háti nyílás alakváltozása a cipzározódásból származó $\left(\mathrm{f}_{\mathrm{z}}\right)$ és az aktomiozin gyürün ható erő $\left(\mathrm{f}_{\mathrm{c}}\right)$ együttes hozzájárulásának köszönhető. A cipzározódás hozzájárulása a háti záródás sebességéhez $\mathrm{f}_{\mathrm{z}}=\mathrm{k}_{\mathrm{z}} / 4 \mathrm{~V}$, míg a záródás fennmaradó része a kontrakcióknak $\left(f_{c}\right)$ tulajdonítható $\left(f_{c}=1-f_{z}\right)$. Az empirikus sebességi egyenlet alkalmazásával kiszámítható, hogy a záródás sebessége milyen mértékben függ a cipzározódástól. Vad típusú záródásnál az $\mathrm{f}_{\mathrm{z}}$ értéke $\sim 1 / 3 \mathrm{az} \mathrm{f}_{\mathrm{c}}$ értéke pedig $\sim 2 / 3$ [13]. 


\section{A sejtváz és szerepe a háti záródásban}

\subsection{A sejtváz általános jelelmzői}

A sejtek jellegzetes szerkezeti eleme a sejtváz (citoszkeleton), mely számos folyamatban fontos szerepet tölt be. A sejtváz egy dinamikusan szerveződött rendszer, amely állandóan változik, lehetővé téve a morfogenezist, a sejtmozgásokat, a sejtalak fenntartását, az intracelluláris transzportfolyamatokat és a sejtosztódást is. Drosophilában a citoplazmatikus sejtváz két fő komponensből épül fel: mikrotubulusokból (MT) és az aktin fimamentumokból.

A MT-ok kb. $25 \mathrm{~nm}$ átméröjü polimer molekulák, melyeket globuláris szerkezetű $\alpha$ - és $\beta$-tubulin alegységekből álló heterodimerek építenek fel. A heterodimerek fej-farok orientációban összekapcsolódnak és fonalszerű struktúrákba, ún. protofilamentumokba szerveződnek (3. ábra A). A MT-ok jellegzetes hengeres formájának kialakulásához 13 protofilamentum laterálisan, egymáshoz képest 0,9 nm-rel elcsúszva illeszkedik egymáshoz (3. ábra B). A MT-ok meghatározott polaritással rendelkeznek. Megkülönböztethetünk gyorsan növekvő (,+”) és lassan növekvő (,,-”) véget. A mínusz vég általában a mikrotubulusorganizáló központhoz (MTOC) kapcsolódik. A MT-ok ,„-” végei az itt található, $\gamma$-tubulinból álló gyürükhöz kapcsolódnak. Egy-egy ilyen gyürü 13 alegységből áll és polimerizációs magként müködik, melyre az $\alpha$ - és $\beta$ - tubulinból álló heterodimerek fokozatosan ráépülnek $[16]$.

A MT-ok ,+" végei dinamikus instabilitást mutatnak, mely során az egyedi mikrotubulusok lassú növekedési fázisból hirtelen rövidülésbe váltanak („katasztrófa”), majd újra növedni kezdenek („,menekülés”). A mikrotubulusok a növekedési fázis után meg is állhatnak („,szünet”), miután újra növekedésbe vagy rövidülésbe kapcsolnak (3. ábra C). In vitro rendszerekben az instabilitás oka a tubulin polimerizációhoz kapcsolt GTP-áz aktivitás. A tubulin monomerek GTP vagy GDP molekulát kötnek. A polimerizáció során az $\alpha$-tubulinhoz kötött GTP GDP-re és foszfátra bomlik, míg a $\beta$-tubulinhoz kötött GTP változatlan marad. A GTP tartalmú heterodimerek beépülése a mikrotubulusba egyenes, míg a GDP tartalmú dimerek beépülése görbült protofilamentumok kialakulását eredményezi. A MT-ok növekedése akkor figyelhető meg, ha a GTP-tartalmú dimerek beépülése gyorsabb, mint az ezt követő GTPhidrolízis. Ilyenkor a MT végeken GTP-tartalmú dimerekből álló „sapka” alakul ki, ami stabilizálja a MT-okat. A növekedés lelassulhat a GTP-tartalmú dimerek koncentrációjának csökkenése miatt és a „sapka” eltűnhet. A hidrolízis következtében GDP-tartalmú dimerek jelennek meg, és ez a MT azonnali szétesését eredményezi, aminek következtében nő a szabad 
tubulin heterodimer koncentráció, amit GDP/GTP kicserélődés követ és újra polimerizáció indulhat el [17].

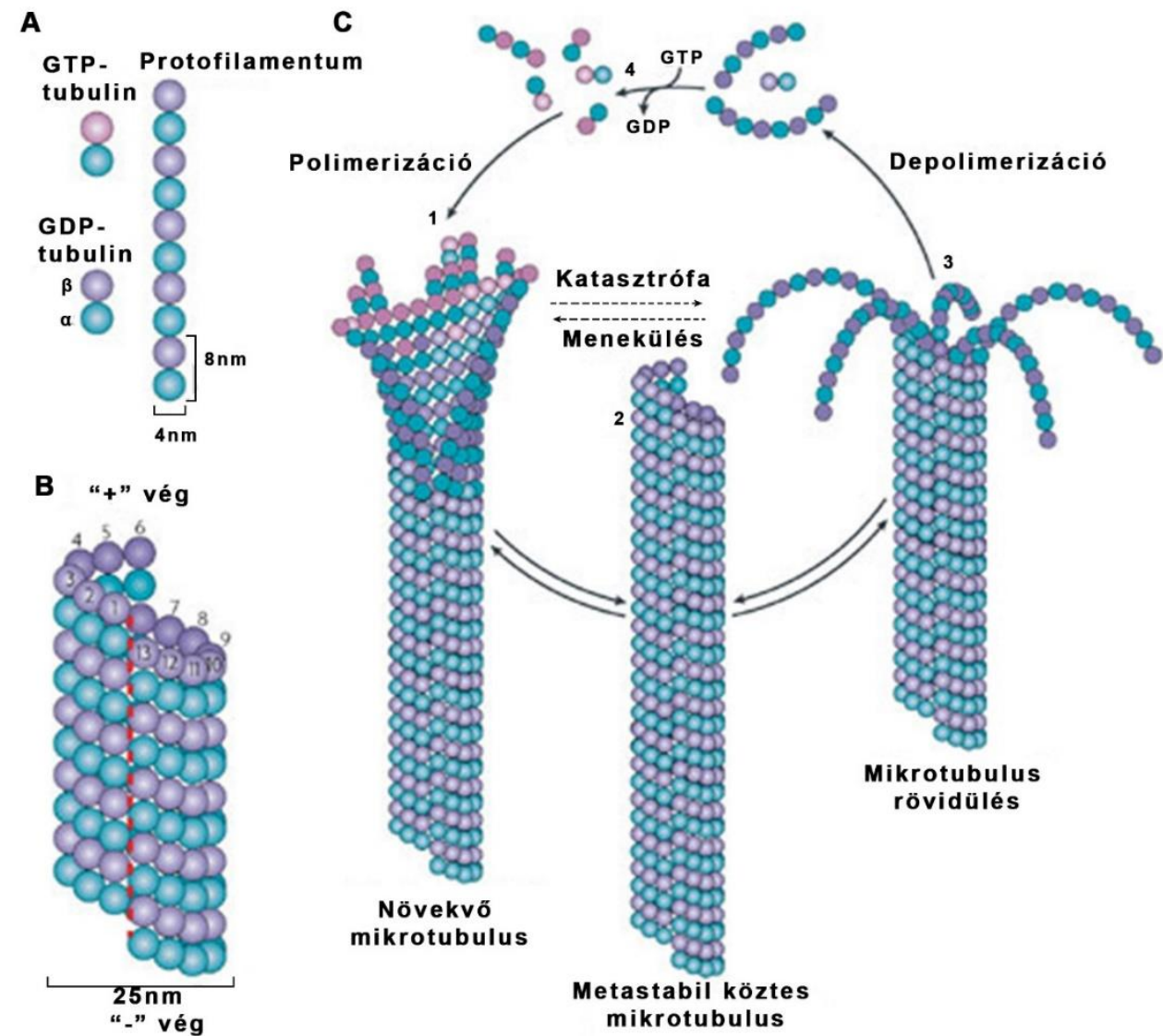

3. ábra. A mikrotubulusok szerkezete és dinamikus instabilitása. (A) A mikrotubulusokat $\alpha$ - és $\beta$ tubulin alegységekböl álló heterodimerek épitik fel, melyek fej-farok orientációban összekapcsolódnak és protofilamentumokba szervezödnek. (B) A MT-ok jellegzetes formájának kialakulásához 13 protofilamentum laterálisan illeszkedik egymáshoz, melyek 0,9 nm-rel el vannak csúszva egymáshoz képest. (C) A MT-ok dinamikus tulajdonságai: 1. Mikrotubulusok növekedése-polimerizáció, 2. Köztes állapotú mikrotubulusok - szünet, miután a MT újra növekedni fog vagy a (3.) depolimerizációs fázisba kapcsol - Mikrotubulusok rövidülése. A polimerizációs-depolimerizációs ciklus a GDP/GTP cseréjével fejezödik be (Akhmanova és munkatársai nyomán) [16]. 
A dinamikus instabilitás következtében a MT-ok hossza több mikron tartományban változhat, ami a MT-ok és végső soron a sejtek müködése szempontjából nagyon fontos MT hálózatok átszerveződését biztosítja. Ha valamilyen vegyülettel megakadályozzuk a dinamikus instabilitást, megakadályozzuk a MT-hoz kapcsolt sejtfunkciók elvégzését is, ami a sejtek elpusztulásához vezet. Az egyik legrégebben ismert ilyen molekula a kolcemid, mely a tubulin heterodimerekhez szorosan kapcsolódva megakadályozza azok polimerizációját és nagy koncentrációban a MT-ok gyors lebomlását okozza [18].

A mikrotubulusok viselkedését jelentősen befolyásolják a mikrotubulusokhoz asszociált fehérjék (microtubule associated protein, MAP). A MAP-ok szerepe sokrétü: elősegítik a MTok növekedését, lebomlását, stabilizálják és kötegekbe rendezik a MT-okat. A MAP-ok egy heterogén csoportját alkotják a „," vég kötő fehérjék (plus-end-tracking protein, +TIP), melyek befolyásolják a MT-ok dinamikus instabilitását. Ilyenek a vég kötő EB1 (end binding 1) fehérjék, melyek evolúciósan konzerváltak és általában a MT-ok növekvő plusz végein találhatók meg [19]. Az EB1 fehérjék dimereket alkotnak. Szerkezetüket tekintve tartalmaznak egy N-terminális kalponin homológia $(\mathrm{CH})$ domént, ami szükséges és egyben elégséges is a MT növekvő „,” vég felismeréséhez, valamint az EB1 MT-hoz való kötődéséhez [20-22]. A $\mathrm{CH}$ domént egy összekötő régió követi. A C-terminálison pedig a dimerizációért felelős coiled coil szerkezetü régió található, mely részleges átfedést mutat egy egyedi szekvencia motívummal, melyet EBH (end binding homology) doménnek is nevezünk, ami az EB1 fehérje kötőpartnereivel való kölcsönhatásért felelös [16,23]. Az EB1 fehérjék más fehérjékkel kétféle képpen léphetnek kölcsönhatásba. Egyrészt a fehérjéken megtalálható Eb1-kötő SxIP motívumon keresztül, ami például az APC, MACF (MT-actin crosslinking factor), CLASPs (CLIP associating proteins) fehérjékre jellemző. A másik lehetőség, a fehérjékre jellemző CapGly (cytoskeleton-associated protein-glycine-rich) domén és az EB1 C-terminálisán található EEY motívumon keresztül valósulhat meg, pl. a CLIP fehérjék vagy a dynactin komplex tagjai kapcsolódnak így [16]. Az EB1 fehérjék befolyásolják a MT-ok „,” vég dinamikáját in vivo és in vitro egyaránt $[24,25]$.

A másik fő sejtváz komponenst Drosophilában az aktin filamentumok alkotják, melyek 7-9 nm átmérőjű helikális szerkezetű aktin polimerek. Az aktin polimereket globuláris G-aktin monomerek építenek fel. Akárcsak a MT-oknak, az aktin polimereknek is határozott polaritásuk van: egy gyorsan növekvő „,+” véggel és egy lassan növekvő „,-” véggel rendelkeznek. A MTokkal ellentétben azonban az aktin filamentumok nem mutatnak drámai dinamikus instabilitást, hanem taposómalom módjára viselkednek (treadmilling): folyamatosan lépnek be monomerek a plusz végen és lépnek ki a mínusz végen, és eközben a filamentum hossza nem változik [26]. 
A változatos szerkezetủ aktinláncok speciális szabályozó fehérjék segítségével alakulnak ki (4. ábra). Ilyenek a szabad filamentumvégeket lefedő fehérjék, melyek megakadályozzák a további polimerizációt vagy éppen a depolimerizációt. A depolimerizációt vagy a filamentum elhasítását elősegítő fehérjék, illetve az új aktinláncok inicializációját elősegítő nukleáló/polimerizációs faktorok is ismertek.

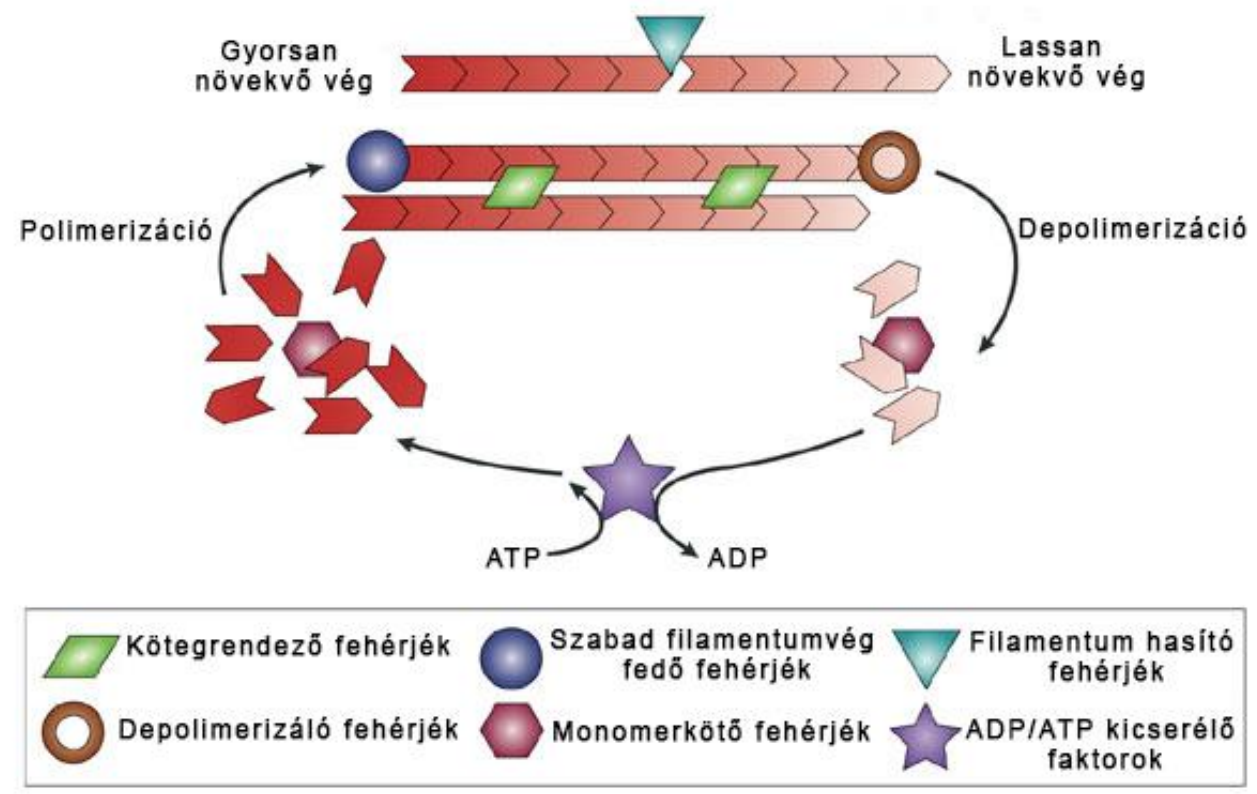

4. ábra. Az aktinfilamentumok dinamikája. Az aktin filamentumok polaritással rendelkeznek. A végek növekedési dinamikája alapján megkülönböztetünk lassan, illetve gyorsan növekvö véget. A változatos szerkezetü aktinláncok speciális szabályozó fehérjék segitségével alakulnak ki [27].

Az aktin filamentumok a járulékos fehérjék segítségével nagyon változatos struktúrákat alakítanak ki, amelyek egyaránt lehetnek stabil vagy instabil képződmények. Stabil képződmény például a sejtkéreg, ami plazmamembrán közelében koncentrálódó aktin hálózat. A dinamikus struktúrákban azonban az aktin filamentumok perces-másodperces időskálán is képesek átépülni. Ilyen dinamikus aktin alapú képződmények a lamellipódiumok és a filopódiumok, melyek folyamatosan alakulnak ki és húzódnak vissza a vezető élen. A lamellipódiumok nagy felületü, lapos kitüremkedések, melyekben az összekapcsolódó aktinfilamentumok sủrü hálózatot alkotnak. A filopódiumok ezzel szemben ujjszerü sejtnyúlványok, melyekben az aktinszálak nem ágaznak el, hanem hosszú, párhuzamos kötegekbe rendeződnek [27].

Az aktin sejtváz müködésében fontos szerepet játszanak a miozin fehérjék, melyek az egysejtü eukariótáktól a gerincesekig mindenütt megtalálható molekuláris motor fehérjék. A nem-izom miozin II (Miozin II) az állati sejtek egyik legfontosabb alkotója, az aktin citoszkeleton átrendeződésében kulcsszerepet játszó, a sejtek minden életszakaszában 
meghatározó jelentőséggel bíró motorfehérje. Drosophilában a zipper (zip) gén kódolja a Miozin II nehéz láncát, ami a háti záródás alatt kialakuló aktomiozin gyürü fontos komponense.

\subsection{A sejtváz múködése a háti záródás alatt}

Felmerül a kérdés, hogy a háti záródásra ható erök hogyan alakulnak ki és az egyes sejtek hogyan szabályozzák azokat molekuláris szinten. Különböző genetikai, biokémiai és sejtbiológiai vizsgálatok segítségével fény derült azokra a szerkezeti és jelátviteli molekulákra, melyek fontos szerepet játszanak a háti záródásban [14]. A háti záródást akadályozó mutációk tipikus ún. „nyitott hát” fenotípust eredményeznek. Az ilyen mutánsokban a háti záródás nem történik meg és az embrió nyitott háttal elpusztul. A háti záródás alatt több jelátviteli útvonal válik aktívvá, melyeknek a fent leírt morfogenetikus sejtmozgások, valamint a sejtalakváltozások szabályozásában van szerepük. A nyitott hát fenotípust okozó gének 3 csoportját különíthetjük el [28].

A háti záródás szabályozásában a DJNK (Drosophila Jun N-terminális Kináz) szignál útvonalnak van központi szerepe. JNK útvonalat elindító szignál még nem ismert, de tudjuk, hogy a háti záródás kezdeti fázisában a DME sejtekben hat, ahol a sejtvázelemek felhalmozódását indukálja. A JNK útvonal bármelyik komponensét (a misshapen (msn), hemipterous (hep), basket (bsk), Jun-related antigen (Jra), kayak (kay), anterior open (aop) és puckered (puc) gének) érintő mutáció esetén ez a felhalmozódás sérül [6, 29-31]. A JNK útvonal egy többlépcsős foszforilációs kaszkád, ami a transzkripciós faktorként müködő Jun fehérje aktiválódását eredményezi, ami végül dimert alkot a Kayak (Kay) fehérjével, létrehozva így az AP-1 transzkripciós faktort (5. ábra). Az AP-1 transzkripciós faktor további célgének expresszióját aktiválja a sejtmagban. Az egyik ilyen célgén a decapentaplegic (dpp), a transzformáló növekedési faktor- $\beta$ (TGF- $\beta$ ) szupercsalád citokinje [31-34].

A háti záródás alatt a JNK jelátvitel emelkedett Dpp szintet tart fenn a DME sejtekben, ami újabb jelátviteli eseményeket aktivál. A Dpp közvetített jelátviteli útvonal komponensei közé tartoznak a Thickveins (Tkv) és Punt (Put) receptorok, valamint a Mothers against dpp (Mad) és a Schnurri (shn) transzkripciós fehérjék. A dpp útvonal komponenseinek vagy targetjeinek mutációi a JNK mutánsokhoz hasonló háti záródás hibákat eredményeznek. A Dpp a TGF- $\beta$ útvonalat aktiválja és a JNK útvonal aktivitásán keresztül tartós Dpp szintet tart fenn a DME sejtekben. A Dpp ligandot a DME sejtek az amnioszerózába és a laterális hámba is 
szekretálják, ahol sejtalakváltozásokat indukál. A Dpp továbbá szükséges a megfelelő aktin sejtváz átrendeződéshez a sejtnyúlványok kialakulása során [35-37].

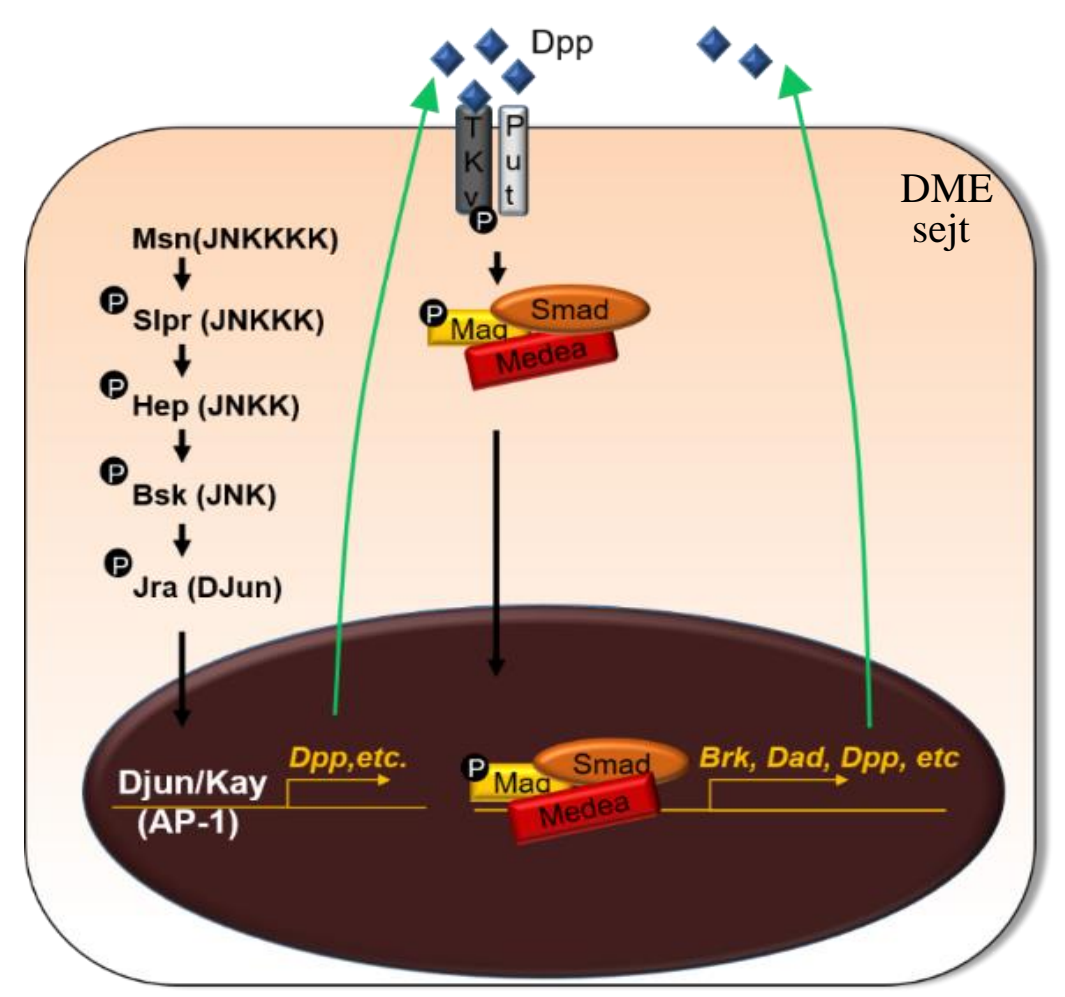

5. ábra. A JNK és Dpp jelátvitel egyszerüsített sematikus ábrája. A JNK útvonal aktiválódása az AP-1 transzkripciós faktor összeszerelödéséhez vezet, ami különbözö célgéneket aktivál a sejtmagban, melyek közül legfontosabb a dpp. Miután a Dpp kötödik a receptoraihoz, egy Mad, Smad, Medea fehérje komplex jön létre, amely bejut a sejtmagba és a Dad és Brk transzkripciós represszor fehérjék kifejezödéssét aktiválja. A dpp sejtalakváltozásokat indukál a DME sejtekben. MSN: Misshapen. Slpr: Slipper. Hep: Hemipterous. Bsk: Basket. Jra: Jun-related antigen. Kay: Kayak. Puc: Puckered Dpp: Decapentaplegic, Tkv: Thickvein. Put: Punt. Mad: Mothers Against Dpp, Brk: Brinker, Dad: Daughters against Dpp.

A Dpp további target fehérjéi a záródás mechanikai effektorait (sejtváz, sejtadhéziós komplexeket, struktúrfehérjéket) kódoló géneket szabályoznak. Ezek a fehérjék lehetővé teszik a háti záródás során létrejövő sejtváz-átrendeződéseket és sejtalak-változásokat. Ilyen például a zipper (zip) gén. A zip gén kódolja a Miozin II nehéz láncát, ami a háti záródás alatt kialakuló aktomiozin gyürű fontos komponense. Az aktomiozin gyürű biztosítja a háti záródás alatt a DME sejtek megnyúlását és az AS sejtek ritmikus kontrakcióját a vezető él sejtjeiben. Miozin II null mutánsok nyitott hát fenotípust mutatnak. A miozin II a hámban, de az AS-ban is fontos szerepet kap, ugyanis mindkét szövetben miozin II transzgént kifejeztetve menekíthető a mutáns fenotípus. A géneknek ebbe a csoportjába tartoznak még a coracle (cora), a canoe (cno) és a myospheroid (mys) gének is, melyek membránasszociált szerkezeti fehérjéket kódolnak és mutációik szintén nyitott hát fenotípust okoznak [38]. 
Bár a háti záródást irányító jelátviteli útvonalak számos elemét azonosították már, a pontos sejtbiológiai események, melyekre ezek hatnak, kevésbé ismertek. Tudjuk, hogy a háti záródás során a hámsejtekben a sejtvázelemek dinamikusan átrendeződnek, ami a háti záródás elején a hámsejtek polarizálódásával kezdődik. Ez molekuláris szinten a sejtvázelemek és a jelátviteli molekulák egyenetlen eloszlásában jelentkezik [39]. Az aktin sejtvázat érintő eseményekért a Rho (Ras homologous) családba tartozó kis molekulasúlyú GTP-ázok felelősek [14]. Drosophilában a Rho fehérjecsalád mindhárom tagja - Rho, Rac, Cdc42-részt vesz a háti záródásban, melyeknek a müködése fokozott aktin polimerizációhoz vezet.

A háti záródás előtt a hámsejtek aktinváza a sejtkéreg minden pontján egyenletes eloszlású. A záródás során azonban a DME sejtek amnioszerózával határos (dorzális) felszínén aktint és miozint halmoznak fel, ezáltal kialakul egy szupracelluláris aktomiozin gyürü, ami a háti nyílást körülveszi. A gyürü kialakulása a RhoA kis GTP-áz müködéséhez köthető, ami a hatását több effektor fehérjéjén keresztül fejtik ki. Ezek közül a legfontosabb a Rho kináz (ROCK). A ROCK képes fokozni a Miozin II könnyü lánc foszforilációs szintjét, ami a Miozin II fokozott aktivitását eredményezi, így kialakul az aktomiozin gyürü és a vezető él megmerevedik [40]. A RhoA hiányában, az embriók, akár funkcióvesztéses mutációt hordoznak, akár a RhoA domináns negatív formáját expresszálják, „nyitott hát” fenotípust mutatnak [41, 42]. Az aktomiozin gyürü hatására a háti záródás frontja „kiegyenesedik”, ami elősegíti a cipzározódást. Ezen kívül a gyürü semlegesíti a hámban kialakuló feszültséget, hogy megelőzze a sebek, szakadások keletkezését [43]. Ha az aktinfelhalmozódás vegyszeres kezelés hatására vagy az aktinregulátorok hibás müködése miatt zavart szenved, akkor a hámlemezek mozgása lelassul és a vezető él sejtjeinek szerkezete is károsodik. Az aktomiozin gyürü hiányában a dorzoventrális sejtmegnyúlás nem jön létre és az anterior/poszterior tengely is véletlenszerü lesz. Habár az aktomiozin gyürü hiánya jelentősen befolyásolja a záródás sebességét, az embriók mégis képesek bezárni a háti nyílást, ugyanis az amnioszeroza által generált húzóerő müködése önmagában elég ehez a folyamathoz [41].

A „cipzározódás” fázisában a DME sejtek dorzális felszínén aktinalapú sejtnyúlványokfilopódiumok és lamellipódiumok- jelennek meg, melyek tubulint, miozint és aktint tartalmaznak $[5,7,8]$.

A lamellipódiumok kialakulásában a Rac 1 kis GTP-áz játszik szerepet, hatására a sejtek elkezdenek vékony lemezszerü kitüremkedéseket, lamellipodiumokat képezni. Mindhárom rac génre ( $R a c 1, R a c 2$ and $M t l$ ) mutáns embriókban az aktin nem halmozódik fel a vezető élben, továbbá filopódiumok és lamellipódiumok sem alakulnak ki [44]. A Rac1 domináns negatív 
formájának expressziója a vezető élre jellemző sejtvázelrendeződés felbomlásához vezet, a tipikus sejtmegnyúlás a hámban eltủnik és a háti záródás sem megy végbe [45].

A Cdc42 a filopodiumok képzésében játszik szerepet. Cdc42 mutáns embriók a Rac és Rho mutánsoktól eltérő, ún. “bunched” szegmens háti záródás fenotípust mutatnak, ami a TGF $\beta$ útvonal komponenseit érintő mutációkra jellemző. Az aktin felhalmozódás a vezető élben nem sérül, viszont a filopódiumok nem alakulnak ki. A filopódiumoknak a környezetüket érzékelő, letapogató szerepük van. Amikor a hámsejtek elég közel vannak egymáshoz a filopódiumok találkozhatnak és ha ezek megfelelő embrionális szegmentből érkeznek, akkor egyesülnek. Filopódiumok hiányában a szemben lévő hámsejtek nem ismerik fel egymást és nem a megfelelő sejt-sejt kapcsolatok alakulnak ki [41].

Bár az aktinváz szerepe a háti záródásban részletesen ismert, a sejtváz másik komponensének, mikrotubulusváznak az elrendeződéséről és működéséről keveset tudunk. Ismert, hogy a záródást megelőzően a hámsejtekben a mikrotubulusok rendezetlenül, helyezkednek el. A háti záródás elején ez a rendezetlen mikrotubulusváz felbomlik és a MT-ok a sejt hossztengelyével párhuzamosan stabil kötegekbe rendeződnek el. A MT-ok átrendeződése elsőként a DME sejtekben indul meg (6. ábra A) és később a laterálisabban elhelyezkedő hámsejtekre is kiterjed (6. ábra B). A MT kötegek stabilak, de az őket felépítő egyedi MT-ok dinamikusan lebomlanak és újra polimerizálódnak. A dinamikus mikrotubulusok a sejtek dorzális felszínén belenőnek a lamellipódiumokba és a filopódiumokba (6. ábra C, D, E), ami arra utal, hogy a sejtnek ezeken a részein a két sejtvázelem szorosan együttműködik. A záródás befejeztével a rendezett MT kötegek lebomlanak és a hámsejtekben ismét rendezetlen MT eloszlás alakul ki.
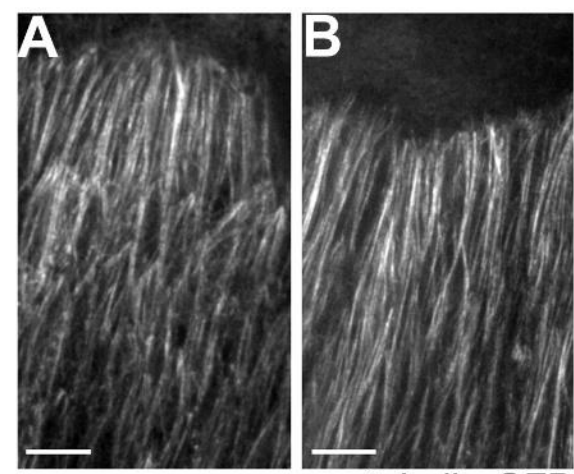

tubulin-GFP

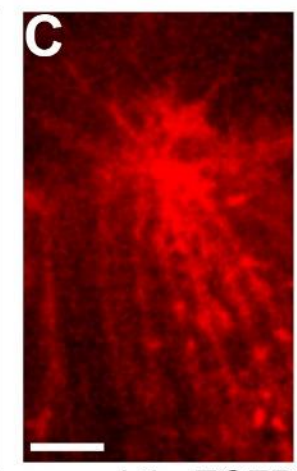

aktin-ECFP

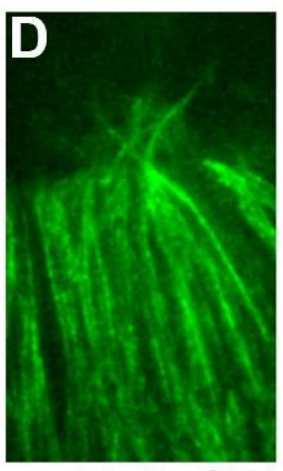

tubulin-GFP

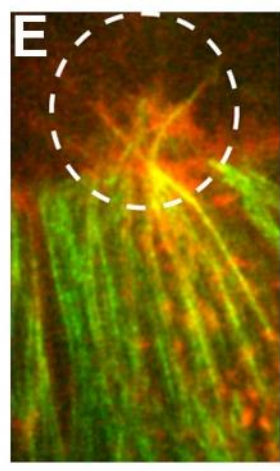

6. ábra. A MT-váz szerkezete a háti záródás alatt. $(A, B)$ élö embriókról készült felvételek mutatják a MT kötegek kialakulását tubulin-GFP-t kifejezö hámban. (A) A háti záródás elején, a MT-ok elösször a $D M E$ sejtekben rendezödnek át. (B) 1 órával késöbb a MT-ok a fennmaradó hámban is párhuzamos kötegekbe rendezödnek. (C) aktin-ECFP-t és (D) tubulin-GFP-t kifejezö DME sejtek élö embriókban a háti záródás vége felé. (E) A MT-ok belenönek a sejtnyúlványokba (szaggatott vonallal körbe rajzolt területen). Mérték $5 \mu \mathrm{m}$ [7]. 
A MT-ok müködése különösen fontos a hámsejtekben és kritikus a háti záródás utolsó, cipzározódási lépéséhez. A MT-ok eltávolítása kolhicin kezelés hatására abnormális háti záródáshoz vezet (7. ábra A), ahol a DME sejtek sejtnyúlványai csökevényesek (7. ábra B). A MT váz felépítésének és szerepének megértésében elért előrelépések ellenére számos kérdés vár még megválaszolásra. Nem ismerjük sem a mikrotubulusváz átrendeződését szabályozó molekulákat, sem azokat a mechanizmusokat, amikkel a mikrotubulusváz a sejtnyúlványok kialakulására hat.

A
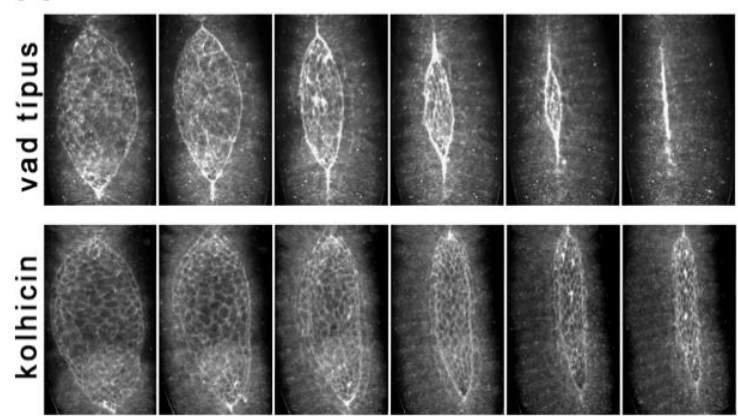

B

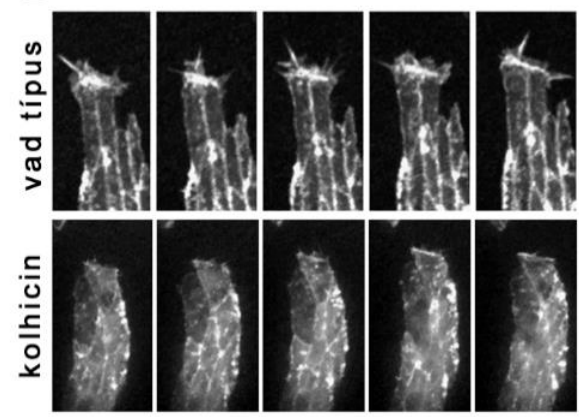

7. ábra. A MT-ok müködése a háti záródás alatt. (A) A MT-ok eltávolítása kolhicin kezelés hatására abnormális dinamikájú háti záródáshoz vezet. (B) kolhicin kezelés hatására a DME sejtek sejtnyúlványai csökevényesek [7]. 


\section{A Spektraplakin fehérjék}

A sejtváz dinamikus átrendeződése az elő szervezetek olyan alapjelensége, amely gyakorlatilag minden sejtre jellemző életének, differenciációjának valamely szakaszában. Hosszú időn keresztül az az elképzelés uralkodott, hogy a sejtváz különböző összetevői egymástól függetlenül, de mégis együtt müködve fejtik ki hatásukat. Ma már azt is tudjuk, hogy a sejtváz komponensei fizikailag szoros kölcsönhatásokat, keresztkötéseket is kialakíthatnak egymással a sejt aktuális igényeitöl, fejlödési állapotától függően. Ezeket a kölcsönhatásokat olyan fehérjék szabályozzák, amelyek egyidejűleg akár többféle sejtvázelemhez képesek kapcsolódni. Erre a feladatra specializálódott például a Spektraplakin fehérjék családja. A Spektraplakinok óriási, evolúciósan konzervált, multidomén szerkezetű fehérjék. A Spektraplakin fehérjék számos feladatot látnak el különböző típusú differenciált sejtekben, amit a moduláris fehérje domén-szerkezetük tesz lehetővé. Többek között részt vesznek a sejt polaritás kialakulásában, morfogenetikus és jelátviteli események, valamint a differenciálódás, migráció folyamatában is. Az OMIM-adatbázis (Online Mendelian Inheritance in Man) alapján mutációjuk szerepet játszik az epidermolysis bullosa simplex öröklődő betegség, valamint az örökletes szenzoros és autonóm neuropátiák kialakulásában. A spectraplakin mutációt hordozó élőlények számos fenotípust mutatnak és gyakran az egyedfejlődés korai szakaszában elpusztulnak [46-48].

\subsection{A Spektraplakin fehérjék jelentősége}

A Spektraplakin fehérjék kulcsfontosságúak minden olyan fejlődésbiológiai folyamatban, ahol a sejtváz szabályozott átrendeződésére, stabilizálására vagy sejt polarizáció kialakulására van szükség. A spektraplakin fehérjék különböző típusú differenciált sejtekben más-más szerepet töltenek be, amit a moduláris protein domén szerkezetük tesz lehetővé. A spektraplakinok valamennyi sejtvázelemmel képesek kölcsönhatásba lépni, keresztkötni azokat vagy adhéziós komplexekhez is kapcsolódhatnak [47, 49, 50]. A spektraplakin fehérjéket kódoló génekről nagyszámú, különböző, akár hét funkcionális doménnel rendelkező fehérje is képződhet, melyek a plakin, spektrin és Gas2-szerü fehérjecsaládok tulajdonságait ötvözik [51, 52]. (1) A plakinok (pl. plectin, desmoplakin, envoplakin, periplakin, epiplakin) olyan vázfehérjék, melyek a sejtváz különböző komponenseit a sejtmembránhoz kapcsolják, valamint fontosak a mechanikai stressznek kitett szöveteben, mint a bör vagy a szív [53]. (2) A spektrin 
fehérjék (pl. $\alpha$-/ $\beta$-spectrin, $\alpha$-actinin, dystrophin és utrophin) evolúciósan konzervált aktin kötő vázfehérjék, melyek elsősorban a sejtkéregben találhatók meg, ahol citoplazmatikus fehérjéket kapcsolnak a sejtmembránhoz [54, 55]. (3) A Gas2-szerü fehérjék (Gas2, Gas2-like 1-3) kapcsolatot alakíthatnak ki a MT, vég-kötő fehérje és az F-aktin között is, hozzájárulva így a sejtváz dinamikus müködéséhez, a sejtosztódáshoz vagy az egyedfejlődéshez [56-58].

Emlősökben két spektraplakin gén található: a Bpag1/Dystonin (bullous pemphigoid antigene1) és az MACF1 (microtubule-actin crosslinking factor1), melyet ACF7-nek (Actin Crosslinking Family 7) is nevezünk. Az ecetmuslica genomjában egyetlen spektraplakin gén, a short stop (shot) található, Caenorhabditis elegans genomjában pedig a vablo gén kódol Spektraplakin fehérjét [59].

A BPAG1e/dystonin a bőrben található meg. Fontos komponense a hemideszmoszómáknak a bazális hámrétegben, ahol mutációja a hám integritásának sérülését okozza, végső soron szakadásokat és hólyagosodást okoz a bőrben. Emberben ezek a tünetek az epidermolysis bullosa simplex öröklődő betegséghez köthetőek [60]. A hosszabb izoforma (BPAG1b) funkcionális hiánya emberben és egérben egyaránt neuronális degenerációhoz vezethet [61-63]. A BPAG1b mutáns egerek dystonia musculorumban szenvednek, hirtelen rángatózó mozgásokat és rendellenes testtartást mutatnak [64, 65]. Megfigyelhető továbbá a MT hálózat felbomlása az axonokban [66]. A BPAG1b mutációja sejt szinten abban nyilvánul meg, hogy a MT-ok nem a polarizált aktin kötegek mentén nőnek és nem reagálnak a polarizált sejtek külső jelzéseire sem [67]. Az MACF1/ACF7 gén mutációja jelenleg nem köthető semmilyen megbetegedéshez, de a mutációt hordozó egerek az egyedfejlődés korai szakaszában, a gasztruláció alatt elpusztulnak. Számos korai fejlődésbiológiai folyamatban is részt vesznek a spektraplakin fehérjék. Többek között a fibroblasztok vagy a bőr őssejtek vándorlásában, de a szív és az agy fejlödésében is szerepük van [68-70].

Drosophilában a shot gén működése kulcsfontosságú a hám épségének megőrzéséhez, az ínsejtek megfelelő tapadásához az izomsejtekhez, de az axonok és dendritek növekedéséhez is esszenciális [71]. Szubcelluláris szinten a Spektraplakin fehérjéknek szerepük van a megfelelő sejt polarizáció kialakításában, a MT-ok stabilizálásában, az aktin polimerizációban és azok kötegekbe szerveződésében [47, 67, 72]. A shot mutációt hordozó muslica embriók különböző fenotípusokat mutatnak. Megfigyelhető a szárny hólyagosodása, az ínsejtek szakadása, a hám integritásának általános sérülése, a tracheaágak fúziájának zavara. A MT hálózat szerveződése sérül a petefészkekben, ezen kívül axon növekedési hibákat, a dendritek hosszának csökkenését és a sejtadhéziós molekulák hibás lokalizációját is leírták shot mutáns axonokban [49, 71, 73-75]. 


\subsection{A Spektraplakin fehérjék szerkezete}

A legtöbb Spektraplakin fehérje N-terminális végén megtalálható egy konzervált szekvencia motívum, mely lehetővé teszi számukra, hogy közvetlenül kapcsolódjanak az aktin vázhoz (8. ábra $\mathrm{A})$. Az F-aktin-kötő domén ( $\mathrm{ABD}$ ) két kalponin homológ, $\mathrm{CH} 1$ és $\mathrm{CH} 2$ régióból áll. A CH1 régió önmagában is képes megkötni az F-aktint, viszont $\mathrm{CH} 2$ régió jelenlétében az ABD F-aktin kötő affinitása megnő [47, 49].

Valamennyi Spektraplakin izoforma tartalmaz egy plakin domént, mely fehérje-fehérje kölcsönhatásokat biztosít, illetve a sejtváz különböző komponenseit a plazmamembránhoz kapcsolja (8. ábra A) [76]. A BPAG1e esetén például a plakin domén juttatja a fehérjét a hemideszmoszómákhoz, ahol az membrán kapcsolt fehérjékhez (például a $\beta 4$ integrinhez) kötődik [77]. A plakin domén egy sorozat spectrin ismétlődést tartalmaz, mely közé egy SH3 domén is beékelődhet [46, 78].

A nagyobb Spektraplakin izoformák középső régiójában található az $\alpha$-hélikális spektrin ismétlődésekből álló (spectrin/ dystrophin repeat rod) domén, mely biztosítja a fehérjék rugalmasságát a mechanikai erőkkel szemben és dimerizáció kialakításában is részt vehet (8. ábra A), továbbá elválasztja az $\mathrm{N}$ - és C-terminálison lévő funkcionális doméneket. A spektrin ismétlődések hossza az optimális fehérje funkció szempontjából kritikus, mivel pl. a disztrofinból már néhány ismétlődés törlése is az izomsorvadás enyhe formáját eredményezi [46, 52, 79].

A C-terminálison három funkcionális domén található (8. ábra A), melyek közül az első a kalcium-függő, két EF-hand motívumot tartalmazó domén [80]. Az EF-hand motívum a leggyakoribb ismert $\mathrm{Ca}^{2+}$ kötő elem, ennek ellenére viszonylag keveset tudunk az EF-hand funkciójáról a Spektraplakin fehérjékben [81]. Az első megfigyelés az MACF1 fehérjéhez köthető, ugyanis ezek a fehérjék $\mathrm{Ca}^{2+}$ stimulus hatására megváltoztatják a sejten belüli eloszlásukat [47].

Közvetlenül az EF-hand domén után található a mikrotubulus-kötő Gas2 (growth arrestspecific 2) /GAR domén, mely eszenciális a mikrotubulusok stabilizálásához. Transzfektált sejtekben a BPAG1, MACF, GAS2, GAR22 és Shot fehérjékből származó izolált GAR domének kolokalizálnak a mikrotubulusokkal [49, 50, 82]. Azok az izoformák, melyek nem tartalmazzák a Gas2/GAR domént általában nem lépnek kölcsönhatásba MT-okkal [46]. Az MACF1 fehérjében jelen van egy másik MT-kötő és -stabilizáló domén is, egy glicin-szerin-arginin gazdag (GSR) domén, amely a Gas2-vel közösen képes a MT-ok kötegekbe rendeződését indukálni [50]. 
A Spektraplakin fehérjék C-terminálisán található a CTD (C-terminális domén), mellyel a mikrotubulusok növekvő, „," végeihez kapcsolódnak egy EB1-kötő SxIP szekvenciamotívumon keresztül (8. ábra A) [83].

A változatos protein domének alternatív splicing és szövet specifikus promóter használat során szabadon kombinálódhatnak egymással, így változatos hosszúságú és funkciójú fehérjék képződhetnek. Drosophilában a fehérjék változékonyságát 43 kódoló exon alternatív splicingja, illetve négy alternatív transzkripciós starthely (P1-4) biztosítja. Ezek a starthelyek négy különböző N-terminálissal rendelkező fehérjének a szövetspecifikus kifejeződését biztosítják, melyeket gyakran Shot-LA,-LB,-LC,-LD-nek is nevezünk (8. ábra B) [84]. 
A

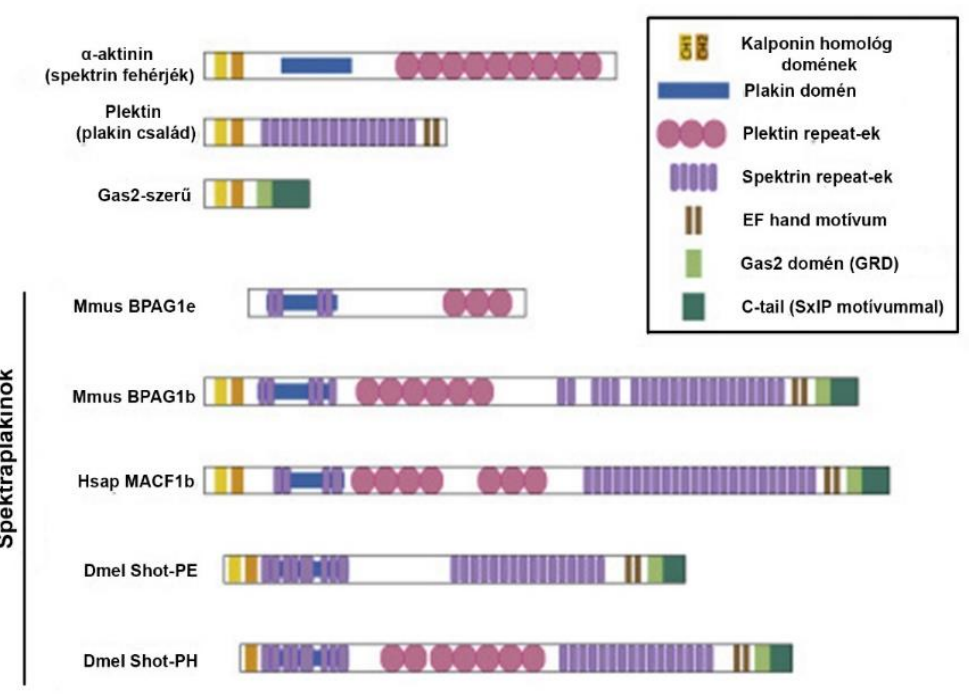

B

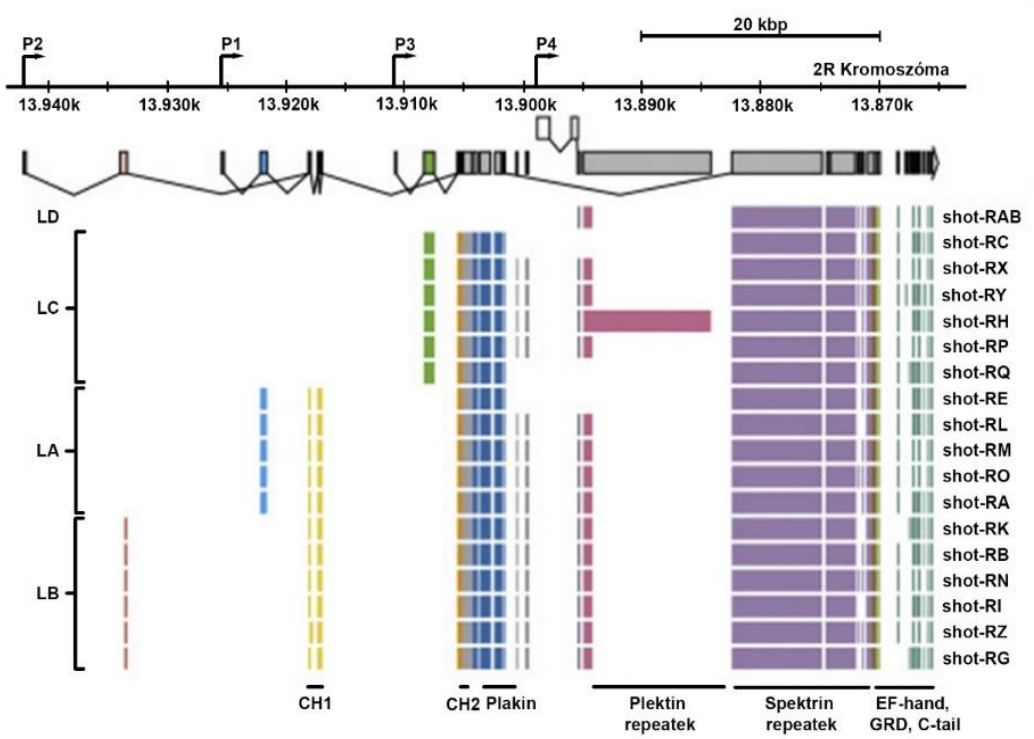

8. ábra. A Shot fehérje homológjai, funkcionális doménjei és legjelentösebb izoformái. (A) A plakin, spektrin és Gas2-szerü fehérjecsaládok tipikus tagjai összehasonlitva a Spektraplakin fehérjék legjelentösebb izoformáival: az egér BPAG1 legrövidebb (e) és leghoszabb (b) izoformái, a humán MACF1 leghoszabb (b) izoformája és a leghoszabb Shot-RE és Shot-RH izoformák. (B) A Shot gén szerkezete. Balról jobbra: Két kalponin homológia domén (CH1 és CH2) alkotja az aktin kötö domént (ABD). A plakin domén, $\alpha$-hélikális spektrin ismétlödésekböl álló (spectrin/ dystrophin repeat rod) domén, EF-hand motivum, Gas2 (growth arrest-specific 2) /GAR domén, CTD (C-terminális domén) mely egy EB1-kötö: SxIP szekvencia-motívumot tartalmaz. FlyBase adatbázis alapján a shot locus 78 kb nagyságú (genomi régió: 13,864,237-13,942,110), 50C6-11 2R kromoszómális hely. A különbözö Shot izoformák (Shot-R/P A-Z, ahol $R$ a transzkriptumokat, $P$ a proteineket jelöli) négy különbözö transzkripciós starthelyröl íródhatnak át (P1-4), ami négy N-terminális izoforma képzödését teszi lehetővé (lásd balra Shot-LA-D). Splicing következtében pedig további 39 különbözö exon és 4 nem kódoló exon képzödhet [84]. 


\section{CÉLKITÜZÉSEK}

Elsődleges célunk a háti záródásban résztvevő, MT-kötő gének azonosítása in vivo video mikroszkópiával kombinált RNS interferencián (RNSi) alapulú funkcióvesztéses szürés segítségével.

RNSi-án alapuló módszer alkalmazásával a muslica számos, MT-okhoz kapcsolódó fehérjéjét egyenként kiiktatjuk és az így kialakult fenotípusos változásokat három hierarchikus szerveződési szinten vizsgáljuk: nagyfelbontású in vivo konfokális mikroszkópia segítségével leírjuk az egyedi MT-ok növekedési és lebomlási dinamikájában bekövetkezett változásokat, élő embriók filmezésével megvizsgáljuk a MT-váz átrendeződését és a MT-kötegek elhelyezkedését, nagysebességű automatizált mikroszkóp alkalmazásával tanulmányozzuk a háti nyílás záródását.

Végső célunk, hogy egy ígéretes jelölt gén részletes sejtbiológiai vizsgálatán keresztül megmutassuk, hogy egy alapető fejlődési folyamathoz hogyan járul hozzá a sejtvázelemek együttmüködése. 


\section{ANYAGOK ÉS MÓDSZEREK}

\section{Drosophila melanogaster törzsek}

A kísérletekben használt Drosophila törzseket szabványos, kukorica-élesztő alapú táptalajon tartottuk. A keresztezéseket $25{ }^{\circ} \mathrm{C}$-on végeztük el. Vad típusként Oregon R törzset használtunk. A háti záródás körvonalát az EGFP-t kifejező ZASP52 ${ }^{\text {ZCL423 }}$ protein-csapda vonal segítségével tettük láthatóvá [31, 85]. Pnr-GAL4 (bloomingtoni törzsközpont (BT) \# 25758) és en-GAL4 (BT \# 30564) driverek segítségével indukáltuk a kiválasztott transzgének expresszióját. Az aktint UAS-actin-EGFP [86], vagy UAS-mCherry-Moesin [9] segítségével, a MT végeket pedig az UASP-Eb1-EGFP [7] felhasználásával tettük láthatóvá. A FRAP kísérletekhez az Ubi- $\beta$-Tubulin-EGFP [87] törzset használtuk fel.

A menekítési kísérleteket a következő shot transzgenikus törzsekkel végeztük el (9. ábra): teljes hosszúságú fehérje (UAS-Shot-L(A)-GFP), UAS-Shot-L(A) $\triangle E F h a n d-G F P(\triangle E F h a n d-$ GFP, hiányzik a $\mathrm{Ca}^{2+}$ ionokat kötő EF-hand motívum), UAS-Shot-L(A) $\Delta$ Gas2-GFP ( $\Delta$ Gas2GFP, hiányzik a Gas2 MT-kötő domén), UAS-Shot-L(C)-GFP ( $\triangle \mathrm{CH} 1-\mathrm{GFP}$, hiányzik a CH1 aktin kötő domén). Ezek a konstrukciók a FlyBase adatbázis alapján nyilvántartott shot-RE mRNS izoformából készültek [49]. További Shot-L(A)-GFP-ből levezetett transzgének: UASShot-L(C) $\Delta$ Gas2-GFP ( $\Delta$ CH1 $\Delta$ Gas2-GFP, hiányoznak a CH1 aktinkötő és Gas2 MT-kötő domének) [49], UAS-Shot-L(A)- $\Delta$ Ctail-GFP ( $\Delta$ C-tail-GFP, hiányzik az EB1 kötő motívum), UAS-Shot-C-tail-GFP (C-tail-GFP csak a C-tail domént tartalmazza), Shot-L(A)-3MtLS*_ GFP (három célzott mutációt tartalmaz, mely a fehérje EB1-Shot interakcióért felelős motívumait érinti) [88], UAS-Shot-EFhand-Gas2-Ctail-GFP (EGC-GFP, MT kölcsönhatásért felelős - Ef-hand, Gas2 és C-tail - doméneket tartalmazza) [89].

A fenotípusok jellemzéséhez a shot ${ }^{s f 20}$ null allélt (kyotoi törzsközpont \# 101311), a shot $^{\text {kakP1 }}$ (BT \# 10522) és shot ${ }^{\triangle E G C}$ izoformaspecifikus mutáns allélokat, valamint a shot gént érintő $D f(2 R) B S C 383$ (BT \# 24407) deléciót használtuk fel. A shot ${ }^{k a k P 1}$ allél egy P-elem inszerciót tartalmaz az első két alternatív transzkripciós strat hely után, de a 3. és a 4. start helyek előtt, így olyan fehérjék termelődnek, melyeknek hiányzik a CH1 aktin kötő doménjük, ezért nem képesek aktint kötni (9. ábra). A shot ${ }^{\triangle E G C}$ allélt újjonan hoztuk létre a laboratóriumunkban (lásd 2. fejezet). 
Mutáns allélok

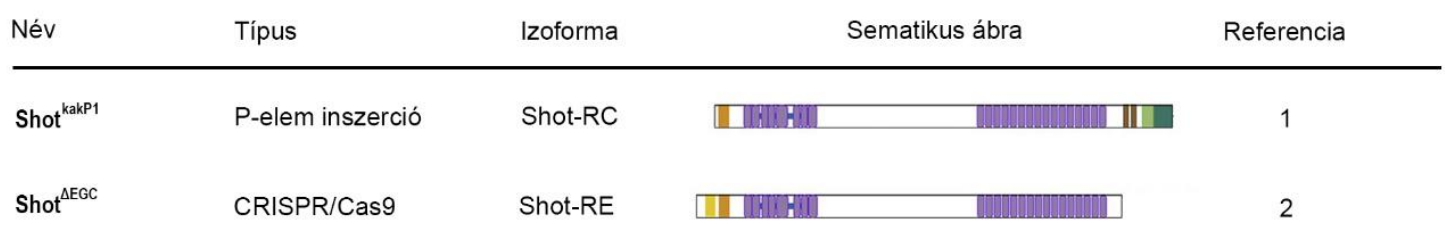

\section{Transzgenikus konstrukciók}

\begin{tabular}{|c|c|c|c|c|}
\hline UAS konstrukt & $\begin{array}{l}\text { Hossz } \\
\text { [deletált régió] }\end{array}$ & Izoforma & Sematikus ábra & Referencia \\
\hline UAS-Shot-L(A)-GFP & 5201 aa [n.a.] & shot-RE & 口I & 3 \\
\hline UAS-Shot- $\triangle \mathrm{CH} 1-\mathrm{GFP}$ & 5160 aa [n.a.] & shot-RC & पIXIRII & 3 \\
\hline UAS-Shot-L(A)- $\triangle E F-$ hand-GFP & 5063 aa [4711-4849] & shot-RE & QIRIIII & 3 \\
\hline UAS-Shot-L(A)- $\Delta C$-tail-GFP & 4918 aa [4919-5201] & shot-RE & MIIIIIIII & 6 \\
\hline UAS-Shot-L(A)- $\Delta$ Gas2-GFP & 5155 aa [4859-4905] & shot-RE & M & 3 \\
\hline UAS-Shot- $\triangle \mathrm{CH} 1-\triangle \mathrm{G}$ as2-GFP & 4859-4905 aa [n.a.] & shot-RC & पMIIIII & 4 \\
\hline UAS-Shot-L(A)-3MtLS -GFP & $\begin{array}{l}5201 \text { aa [4966-9,5077, } \\
5141-4 \text { cseréje AAAA-ra] }\end{array}$ & shot-RE & एUIXIII & 6 \\
\hline UAS-C-tail-GFP & 4918-5201 aa [n.a.] & shot-RE & 10 & 6 \\
\hline UAS-EGC-GFP & 4780-5201 aa [n.a.] & shot-RE & III $\bigcirc$ & 7 \\
\hline
\end{tabular}

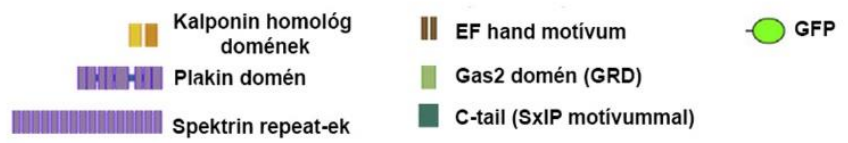

9. ábra. A kísérletekhez felhasznált izoforma specifikus shot mutáns allélok és GFP-vel jelölt csonkolt doménszerkezetü UAS transzgenikus konstrukciók. A sematikus ábrák a 8. ábra nyomán készültek. A csillag a mutáns szekvenciát jelöli. Referenciák: 1- [74], 2- [90], 3- [49], 4- [91], 5- [92], 6- [88], 7[89]. 


\section{Shot ${ }^{\triangle E G C}$ mutáns allél létrehozása CRISPR/Cas9 módszerrel}

Kiméra (chimeric, Chi) RNS-ek klónozása pU6-BbsI-chiRNA vektorba

A shot gén EF-hand, Gas2, C-terminális (CT) doménjeit kódoló genomi szakaszra szekvencia-specifikus, 20 nukleotid hosszúságú oligonukleotidokat terveztünk a Crispr Optimal Target Finder programmal (10. ábra). A kiválasztott szakaszok specificitását a BLAST analízissel ellenőriztük.

Az oligonukleotidokatkat foszforiláltuk: $2 \mu 110 \mu \mathrm{M}$-os oligó, $2 \mu 110$ mM-os ATP, $2 \mu 1$ 10x T4 PNK pufferA, $1 \mu 110$ U/ $\mu 1$ T4 polinukleotid kináz, $13 \mu 1$ UP (ultra pure) víztartalmú reakcióelegyet 1 órán át $37^{\circ} \mathrm{C}$-os vízfürdőben tartottuk. Majd a kináz enzimet hőinaktiváltuk úgy, hogy a reakcióelegyet 10 percig $75^{\circ} \mathrm{C}$-os vízfürdőbe raktuk.

Az oligonukleotidok szensz én antiszensz szálát hibridizáltuk: 10-10 $\mu 110 \mu \mathrm{M}$-os oligonukleotidot $80 \mu$ l annealing pufferben (10 mM Tris pH 7.5, 0,1 mM NaCl, 1 mM EDTA) hibridizáltuk úgy, hogy a reakcióelegyet $95^{\circ} \mathrm{C}$-ra melegítettük, majd lassan $25^{\circ} \mathrm{C}$-ra hütöttük vissza.

A hibridizált oligonukleotidokat pU6-BbsI-chiRNA expressziós vektorba klónoztuk: A pU6-BbsI-chiRNA plazmidot BbsI restrikciós enzimmel emésztettük, majd Fast AP (alkalikus foszfatáz) enzimmel defoszforiláltuk. A hibridizált oligonukleotidokat emésztett, defoszforilált pU6-BbsI-chiRNA plazmidba ligáltuk. A ligálást 2 órán keresztül $18{ }^{\circ} \mathrm{C}$-on végeztük. A ligálási reakcióelegy $6 \mu 1$ 0,1 $\mu \mathrm{M}$-os oligót, $2 \mu 1$ 10x-es T4 DNS ligáz puffert, $1 \mu 120$ ng/ $\mu 1$ pU6-BbsI chiRNA plazmid DNS-t, $1 \mu 15$ U/ $\mu 1$ T4-DNS-ligáz enzimet és $10-\mu 1$ UP vizet tartalmazott. A hibridizált oligonukleotidokat tartalmazó pU6 plazmidokat 2T1 E. Coli kompetens sejtekbe transzformáltuk. A transzformáláshoz $20 \mu \mathrm{l}$ ligátumot adtunk $200-\mu 1$ sejthez. A sejteket 30 percig jégen inkubáltuk, majd $42{ }^{\circ} \mathrm{C}$-os vízfürdőben 1 perc 15 másodperces hősokkot alkalmaztunk. A hősokk után a kompetens sejteket 2 percre jégre raktuk. A sejtekhez $800 \mu 1$ LB tápoldatot adtunk, majd 1 órán át $37{ }^{\circ} \mathrm{C}$-on inkubáltuk azokat. A sejteket $100 \mu \mathrm{g} / \mathrm{ml}$ koncentrációjú ampicillint tartalmazó LB lemezekre szélesztettük, és 16 órán át $37{ }^{\circ} \mathrm{C}$-on növesztettük. 
-ccalagatacttgtttaatcccc-CTTTAAGGGATCTCGTGACCAGGGACTCAATGCCCGC AAGGGAAG—TCGTATCACGCCCACACGTGACACGCCCGACAGAGATCGCCTGCCGCACTATGGCC CCCGATTCTCGCCAAG—CACCTCGGGACCGGAACTGGAAT TCCGTTCGCCACGCGCGAAGCT TCT GTGGACCAAGTGGCGCGATGTCTGGATGCTCTCATGGGAGCGCCAGCGGCTGCTTAACGATCATCTTC TGTATCTGAAGGATGTGGAGCGTGCCCGCAACTTCAGCTGGGACGATTGGCGCAAGCGC- — TTCCT CAAGTACATGAACCACAAGAAGTCGCGCTTGACGGATCTGTTCCGGAAAATGGATAAGGATAACAATG GCATGATTCCGCGCGATGTCTTCATCGATGGCATACTCAATACGA-AATTCGATACATCTGGCTT GGAAATGAAGGCT GTAGCCGATTTGTTCGATCGCAAT GGCGAAGGCCTCATCGACTGGCAAGAGTTCA TTGCTGCCCT TCGTCCCGATTGGCAAGAGCGTAAGCCAGCCAATGATTCGGACAAAATACACGATGAG GTCAAACGTCTGGTCATGCTGT GTACCTGCCGACAGAAGTTCCGTGTGT TCCAAGTTGGCGAGGGCAA GTACAGA——TTGGAGACTCCCAGAAACTGCGCCTCGTTCGTATCCTTCGCAGCACTGTTATGGTG CGCGTGGGTGGCGGTTGGGTTGCCCTGGATGAATTCCTGCAGAAGAACGATCCTTGTCGCG-CCC agatactgtgcatcgtttgc-CCAAAGGACGCACTAACATAGAGCTACGCGAGCAATTCATATTG GCCGATGGCGTCTCGCAGAGCATGGCCGCATTCACGCCCAGACGTTCCACGCCAAATGCGGCCGCCAC TGCCTCCTCCTCACCCCATGCCCACAATGGCGGCAGCTCCAACTTGCCCCCATATATGAGTGGACAGG GTCCCATCATCAAG—GTACGCGAGCGCTCCGTCCGCTCGATTCCCATGTCACGACCGTCGCGCTC CTCACTTTCGGCCAGCACTCCCGACTCCCTGAGCGACAACGAGGGTAGCCATGGAGGACCTTCCGGCC GGTACACACCACGCAAGGTCACCTACACGAGCACGCGCACGGGTCTCACGCCAGGAGGCTCTCGTGCC GGCTCCAAGCCCAACTCGCGCCCGCTCAGCAGACAGGGATCAAAGCCGCCATCGCGACATGGCTCCAC GCTGTCGCTAGATAGCACGG_ACGATCACACGCCCTCACGCATTCCGCAACGCAAGCCTTCAACG GGCAGCACAGCCAGCGGTACCACTCCGCGTCCGGCGCGACTTTCGGTGACCACCACCACGACTCCCGG CAGTCGTCTCAATGGCACCAGCACCATTACCCGCAAAACCGCCTCCGGATCGGCTAGTCCGGCGCCCA CAAG-CAACGGAGGCATGAGTAGATCATCCAGTATACCAGCACTAACAGGCTTCGGCTTCAAACC AATTAG-GCGAAACATCAGCGGTAGCTCAACGCCCTCCGGGATGCAAACGCCGCGAAAGAGCTCA GCGGAGCCCACATTCAGCTCCACAATGAGACGCACTTCGCGGGGAACCACACCGACGGAGAAGCGTGA GCCATTCCGGCTATAG

\section{1. ccaagatacttgtttaaatcccc}

szensz: CTTCGgGGATTTAAACAAGTATCT

antiszensz: AAACAGATACTTGTTTAAATCCCC

\section{2. cccagatactgtgcatcgtttgc}

szensz: CTTCGCAAACGATGCACAGTATCT

antiszensz: AAACAGATACTGTGCATCGTTTGC

10. ábra. A shot gén EF-hand (zöld), Gas2 (kék), CT (barna) doménjeit kódoló genomi szakasz. ChiRNS-ek szekvenciái (piros), szensz szál, amiben benne van a PAM szekvencia 3'végen (türkisz), antiszensz szál, amiben a PAM szekvencia reverz komplementere van az 5'végen (kék), A nyilak a hasitás helyét mutatják. A szekvenciát megszakitó fekete vonalak további nukleotidokat jelölnek.

\section{$\underline{\text { Plazmid DNS tisztítás }}$}

A telepeket egyenként, $0,1 \mathrm{mg} / \mathrm{ml}$ koncentrációjú ampicillint tartalmú folyékony LB tápoldatba oltottuk és $37{ }^{\circ} \mathrm{C}$-on inkubáltuk egy éjszakán keresztül. A plazmid DNS-eket QIAPrep Spin Miniprep Kit (QIAGEN) felhasználásával tisztítottunk. A sejteket centrifugálással ülepítettük, majd felszuszpenzáltuk $250 \mu \mathrm{l}$ P1 pufferben (reszuszpenziós puffer) és $250 \mu 1$ P2 pufferrel (lízis puffer) lizáltuk. A lizált sejtekből a fehérjéket $350 \mu 1$ N3 pufferrel (neutralizáló puffer) csaptuk ki, amit 10 perces centrifugálással ülepítettünk. A felülúszót egy perces centrifugálással DNS-kötő oszlopon folyattuk át. Az oszlopot PE pufferrel (mosó puffer) mostuk át, majd a maradék mosópuffert egy perces centrifugálással 
távolítottuk el. A plazmid DNS-t az oszlopról $65{ }^{\circ} \mathrm{C}-\mathrm{os}, 50-\mu 1 \mathrm{~EB}$ pufferel (eluáló puffer) oldottuk le. A mintákból 1-1 $\mu$ l-t megfuttattunk 1\%-os agaróz gélen, majd a plazmid DNS-ek szekvenciáját T7 primerek felhasználásával határoztuk meg a Microsynth Austria GmbH szekvenáló labor közremüködésével.

A transzgenikus muslicák előállításához a megfelelő szekvenciájú DNS-t tartalmazó telepeket $3 \mathrm{ml}$ 0,1 mg/ml koncentrációjú ampicillint tartalmú folyékony LB tápoldatba oltottuk le és $37{ }^{\circ} \mathrm{C}$-on inkubáltuk 8 órán keresztül. A felnőtt baktérium kultúrából $100 \mu$ l-t átmértünk

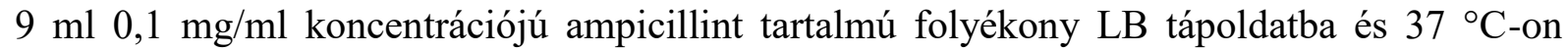
inkubáltuk egy éjszakán keresztül. A plazmid DNS-t QIAGEN Plasmid Mini Kit felhasználásával tisztítottuk. A sejteket centrifugálással ülepítettük, majd felszuszpenzáltuk 400 $\mu 1$ P1 pufferben (reszuszpenziós puffer) majd $400 \mu 1$ P2 pufferben (lízis puffer) 5 percig lizáltuk. A lizált sejtekből a fehérjéket $400 \mu 1 \mathrm{~N} 3$ pufferrel (neutralizáló puffer) csaptuk ki. A kicsapódott fehérjéket $4{ }^{\circ} \mathrm{C}$-on 15 perces centrifugálással ülepítettük. A QIAGEN oszlopot 1 ml QBT pufferrel ekvilibráltuk, majd a felülúszót rámértük az oszlopra. Az oszlopot 2 x $2 \mathrm{ml}$ QC oldattal mostuk át. A plazmid DNS-t $800 \mu 1$ QF oldattal eluáltuk, majd $56 \mu 1$ izopropanollal kicsaptuk. A kicsapott DNS-t $4{ }^{\circ} \mathrm{C}$-on 30 perces centrifugálással ülepítettük, majd $1 \mathrm{ml} 70 \%$ os etanollal mostuk. A csapadékot 3 percig centrifugáltuk, majd 96\%-os etanollal mostuk. A leülepített csapadékot vákuumban szárítottuk, majd $10 \mu$ injektáló pufferben $(5 \mathrm{mM} \mathrm{KCl,} \mathrm{0,1}$ $\mathrm{mM}$ foszfát puffer $\mathrm{pH}: 6,8)$ oldottuk fel.

\section{A chiRNS-eket hordozó pU6 plazmid injektálása}

$W^{1118}$, vasa-Cas9 genotípusú Drosophila törzset 30 percig petéztettük, majd összegyüjtöttük a lerakott petéket és 1 percig 50\%-os hipóval dekorionizáltuk azokat. A petéket ragasztóval (heptánban oldott kétoldalú ragasztószalag, 3M) bevont fedőlemezen a háti oldallal lefelé fordítva egyenként sorba rendeztünk és Halocarbon7S (VWR) olajjal lefedtük. Injektáló pufferben $\left(5 \mathrm{mM} \mathrm{KCl}, 0,1 \mathrm{mM} \mathrm{Na} 3 \mathrm{PO}_{4}, \mathrm{pH}: 6,8\right)$ oldott $250 \mu \mathrm{g} / \mu$ l koncentrációjú kiméra RNSeket tartalmazó oldatot Transjector 5246 (Eppendorf) injektort használva üvegkapillárissal az embrió poszterior részébe injektáltuk. Egy-egy oldattal átlagosan 100 embriót injektáltunk.

\section{$\underline{\text { A chiRNS-ek tesztelése egy embriós PCR-rel }}$}

Az injektált embriókat heptánnal lemostuk egy petricsészébe majd egyenként eppendorf csőbe raktuk át azokat. Az embriókat $20 \mu$ proteináz K-t tartalmazó oldatban szétnyomtuk (900 $\mathrm{u} / \mu 1$ proteináz $\mathrm{K}, 10 \mathrm{mM}$ Tris $\mathrm{pH} 8,2 ; 1 \mathrm{mM}$ EDTA, $25 \mathrm{mM} \mathrm{NaCl}$ ) és $37^{\circ} \mathrm{C}$-os vízfürdőben 40 percig inkubáltuk. A proteináz $\mathrm{K}$ hatását 5 percig $95^{\circ} \mathrm{C}$-os vízfürdőben inaktiváltuk. $\mathrm{PCR}$ 
reakciót $15 \mu$ térfogatban végeztük $\left(+\left(\mathrm{NH}_{4}\right)_{2} \mathrm{SO}_{4}\right.$ puffer, $2,5 \mathrm{mM} \mathrm{MgCl} 2,1 \mathrm{mM}$ dNTP mix, 28 ng/ $\mu 1$ DNS, 0,01 U/ $\mu 1$ Taq DNS polimeráz) a következő programmal: $95{ }^{\circ} \mathrm{C} 2 \mathrm{p}, 34 \times\left(95{ }^{\circ} \mathrm{C} 30\right.$ mp, $58{ }^{\circ} \mathrm{C} 1$ perc $\left.30 \mathrm{mp}, 72{ }^{\circ} \mathrm{C} 1 \mathrm{p}\right), 72^{\circ} \mathrm{C} 4$ percig. A keletkezett termékek méretét $1 \%$-os agaróz gélen ellenőriztük. A felhasznált primerek szekvenciái: forward: aacgtcttgcacacctatctct, reverz: gagtagatggtacaacccttgg.

Deléciót hordozó shot mutáns törzs létrehozása

A sikeres injektálás után a deléció izolálásához a shot lókuszt lefedő, nagyméretü $D f(2 R) B C 383$ deficiencia felhasználásával komplementációs analízist végeztünk el (10. ábra).

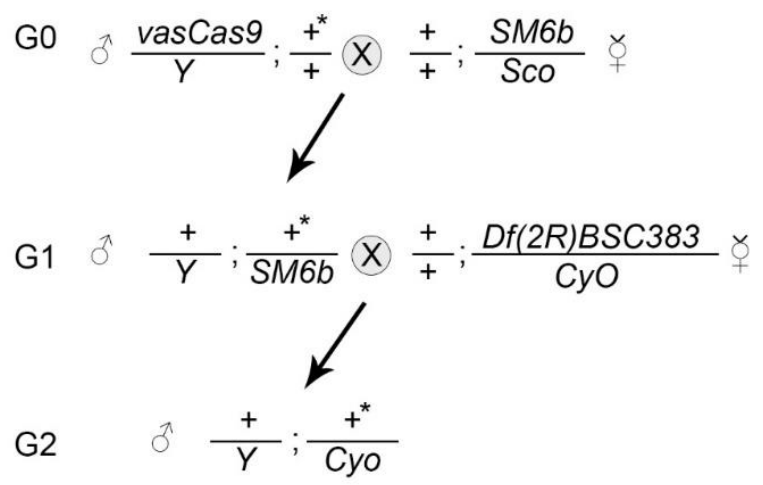

11. ábra. Shot ${ }^{A E G C}$ mutáns allél izolálása. A komplementációs analizis keresztezési sémája. $A+* a$ mutagenizált 2. kromoszómát jelöli. 


\section{Géncsendesítés Drosophila embriókban}

\section{Géncsendesítő kettős szálú RNS-ek elöállítása}

A csendesítésre kiválasztott génekre (1. táblázat) homológ kettős szálú (ds) RNS-eket terveztünk. A gének szekvenciáit a FlyBase adatbázisból (http://flybase.org) töltöttük le. Az esetleges off-target hatást a dsCheck online szoftverrel ellenőriztük. A kiválasztott szekvenciákhoz pontosan illeszkedő, komplementer primereket terveztünk a Primer3 program segítségével. A primereket PCR reakcióban használtuk fel. A PCR során szigorúan ügyeltünk a megfelelő paraméterek optimalizálására. 18-20 nukleotid hosszúságú primereket terveztünk, melyek GC:AT arányát 50-60 \% közé állítottuk be. Olvadási hőmérsékletnek optimálisan 58 ${ }^{\circ} \mathrm{C}$-ot állítottunk be. Továbbá feltételként szabtuk meg, hogy egymás után maximum 3 egyforma nukleotid következzen. A termékek hossza 400-700 nukleotid közé esett. A primerek 5' vége elé T7 promóter szekvenciát (5'-TAATACGACTCACTATAGGG-3') illesztettünk.

A PCR reakciót $100 \mu$ térfogatban végeztük $\left(+\left(\mathrm{NH}_{4}\right)_{2} \mathrm{SO}_{4}\right.$ puffer, $2,5 \mathrm{mM} \mathrm{MgCl}, 1$ mM dNTP mix, $28 \mathrm{ng} / \mu 1 \mathrm{DNS}, 0,01 \mathrm{U} / \mu \mathrm{l}$ Taq DNS polimeráz) a következő programmal: 94 ${ }^{\circ} \mathrm{C}$-on $1 \mathrm{p}, 24 \mathrm{x}\left(55-60{ }^{\circ} \mathrm{C}\right.$-on $\left.1 \mathrm{p}, 72{ }^{\circ} \mathrm{C} 1 \mathrm{p}\right)$. A PCR reakciók termékeit „QIAquick PCR Purification Kit (QIAGEN)" segítségével tisztítottuk meg, a fragmentek méretét 1\%-os agaróz gélen ellenőriztük, koncentrációjukat Nanodrop műszerrel mértük.

Az in vitro transzkripcióval az amplifikált DNS szakaszokról RNS-t készítettünk Promega T7 RiboMAX ${ }^{\mathrm{TM}}$ készlet segítségével. 2 x puffert (RiboMAX Express T7), $1 \mu \mathrm{g}$ PCR termékeket és T7 enzim mixet mértünk össze és 1 óráig $37{ }^{\circ} \mathrm{C}$-on inkubáltuk. 1 óra után a mintákhoz mértünk $1 \mu 1$ DNáz oldatot és tovább inkubáltuk $37^{\circ} \mathrm{C}$-on 30 percig.

Az RNS molekulák kinyeréséhez RNS kicsapást végeztünk. 0,1 tf 3M Na-acetát oldatot és $1 \mathrm{tf}$ izopropanolt adtunk a mintákhoz és 10 percig jégen hagytuk. $4^{\circ} \mathrm{C}$-on $13000 \mathrm{rpm}$-el 15 percig centrifugáltuk, a felülúszót óvatosan leszívtuk, majd $-20{ }^{\circ} \mathrm{C}$-os $70 \%$-os etanolban mostuk, majd újra $4{ }^{\circ} \mathrm{C}$-on 13000 rpm-el 10 percig centrifugáltuk és a felülúszót leszívtuk. A termékeket vákuumban beszárítottuk (1 perc) és az RNS molekulákat RNáz mentes vízben oldottuk fel. Az RNS-ek méretét 1,5\%-os agaróz gélen ellenőriztük, koncentrációjukat Nanodrop müszerrel mértük. Az $1 \mu \mathrm{g} / \mu 1$ koncentrációra hígított dsRNS oldatokat $-20^{\circ} \mathrm{C}$-on tároltuk felhasználásig.

Végül az RNS-ket duplaszálú RNS-ké (dsRNS) hibridizáltuk össze úgy, hogy a PCR készülékben $60{ }^{\circ} \mathrm{C}$-ra melegítettük a mintákat és fokozatosan hütöttük le. $1 \%$-os agaróz gélben elválasztva TAE puffer felhasználásával ellenőriztük a dsRNS-ek jelenlétét és lemértük a koncentrációjukat. 


\begin{tabular}{|c|c|c|c|c|}
\hline & \multirow{2}{*}{ gének } & \multicolumn{2}{|c|}{ primerek 5'-3' irányban } & \multirow{2}{*}{$\begin{array}{c}\text { ds RNS } \\
\text { koncentráció } \\
\mu \mathrm{g} / \mu \mathrm{I}\end{array}$} \\
\hline & & forward & reverz & \\
\hline 1. & Msps & ACGGAACGCGAAATAACC & AACGGTTGTCGTGGTCAG & 4,2 \\
\hline 2. & clip190 & GGGTGTTGTCCTTGACGA & GGGTGTTGTCCTTGACGA & 3,9 \\
\hline 3. & Eb1 & GATCGCCACGTGATTAAATAG & ACGAGTCTGTGAACCTTTCAA & 2,9 \\
\hline 4. & Apc & TTTCGTCGTGGAGATTGG & ATGCAGAAGCGGAAGTCA & 2,9 \\
\hline 5. & Apc2 & AGAGACGATCCGCTCAGAC & TCCCTTCTCGGAGATTGAG & 4,1 \\
\hline 6. & shot & AACCCACAGCTCCCAGAT & TGGCAACAAAGCTGATCC & 5,42 \\
\hline 7. & Glued & TTGCCCAACATCTTCTGG & GTGGACGTGTTGCCTGAT & 4,03 \\
\hline 8. & Dhc64C & CAAGTTGCGACACCTTCTG & GTGGCTTGGATTACCGAAC & 3,74 \\
\hline 9. & Klp10A & GGAATCGACTGGCTTTCC & GGGCAAGTGCATCACAGT & 3,91 \\
\hline 10. & Klp59C & GAATGCTGACCACATCCTG & TGCGTGGTAAGGAACTGC & 2,69 \\
\hline 11. & CG13366 & ATCCAGCACTTCGCTCAG & ACTTGCAAACCCAGCTGAC & 3,49 \\
\hline 12. & katanin60 & CTCGTTGGTGTTCGATGTG & CAAGGCCATTCAGAGAACC & 3,09 \\
\hline 13. & Lis-1 & TCTGGGCTCAAATGGCTA & TCGTTATGCTGGCACGAT & 2,60 \\
\hline 14. & Patronin & ATTTCCGGGAGATTTGACAC & GATAGGTGAGATTGCCGCT & 4,36 \\
\hline 15. & Spastin & TCCTCTGTGCACAAACAGAAC & CATTCAACCGTTGGAGA & 6,03 \\
\hline 16. & chb & TCCACGCTAAGGACATGG & CTGCGGCTGAGTGTGATAG & 4,10 \\
\hline 17. & $\operatorname{ssp} 2$ & TGAACGGATGAACAACTCG & TCCGCTGTAGTAGCACTCG & 3,49 \\
\hline
\end{tabular}

1. táblázat A kiválasztott génszakaszokra specifikus primerek szekvenciái és a dsRNS oldatok koncentrációja. 


\section{$\underline{\text { Drosophila embriók injektálása }}$}

A ZASP52 ZCL0432 genotípusú Drosophila törzset szén és agar tartalmú táptalajon petéztettük 30 percig. A 0-30 perces embriókat összegyüjtöttük és 1 percig 50\%-os hipóval $(\mathrm{NaOCl})$ dekorionizáltuk azokat. Az embriókat a háti oldallal lefelé fordítva egyenként sorba rendeztünk és ragasztóval (heptánban oldott kétoldalú ragasztószalag, $3 \mathrm{M}$ ) bevont tárgylemezre rögzítettük, majd Halocarbon7S (VWR) olajjal lefedtük. A dsRNS-eket injektáló pufferben ( $5 \mathrm{mM} \mathrm{KCl,} \mathrm{0,1} \mathrm{mM} \mathrm{Na} 3 \mathrm{PO}_{4}, \mathrm{pH}$ : 6,8) oldottuk fel. $1 \mu \mathrm{g} / \mu$ l töménységü kettős szálú RNS-oldatot a Transjector 5246 (Eppendorf) injektort használva üvegkapillárissal a szincíciális blasztoderma stádiumú embriók laterális részébe injektáltuk. A kapillárisokat Flaming/Brown P-97 (Sutter Instrument Co.) micropipetta-húzóval állítottuk elő. A kísérlet végrehajtásához speciális tárgylemeztartót terveztünk és gyárttattunk le, mely alkalmas volt 14 tárgylemez egyidejü tárolására.

\section{In vivo mikroszkópia}

A dsRNS-sel injektált embriókat 7 óráig $25{ }^{\circ} \mathrm{C}$-on tartottuk, majd a háti záródásról automatizált in vivo fluoreszcens video mikroszkópiával 12 órás filmeket készítettünk egy programozható Olympus CellR spinning disc kvázi-konfokális fluoreszcens mikroszkóppal. A filmezéshez 10X objektívet és F-View II kamerát (Soft Imaging System, Münster) használtunk. A mikroszkóp és a kamera beállításait a nagyszámú embrió egyidejü filmezéséhez optimalizáltuk. Az egyes embriók pozícióját kézzel állítottuk be. A filmeket tiff formátumban tároltuk és a felvételeket az Image J szoftver segítségével jelenítettük meg. A dsRNS-sel kezelt embriók publikációs minőségü képeit Leica TCS SP5 konfokális vagy VisiScope spinning disc konfokális mikroszkóppal készítettük el.

A mutáns háti záródás számszerüsítéséhez az EGFP-t kifejező ZASP52 ${ }^{\text {ZCL0432 }}$ proteincsapda vonalat használtuk $s h o t^{s f 20} / \operatorname{shot}^{s f 20}$, shot ${ }^{k a k P 1} / \mathrm{Df}(2 \mathrm{R}) \mathrm{BSC} 383$, shot ${ }^{4 E G C} / \mathrm{Df}(2 \mathrm{R}) \mathrm{BSC} 383$ és $s h o t^{k a k P 1} /$ shot $^{\Delta E G C}$ genotípusú embriókban.

A háti záródás fenotípus menekítéséhez különböző Shot fehérje változatokat fejeztettünk ki $s h t^{s f 20}$, UAS-mCherry-Moesin/ Df(2R)BSC33; pnr-Gal4/+ mutáns háttéren. A filmeket Leica TCS SP5 konfokális fluoreszcens mikroszkóppal rögzítettük. A háti nyílás hosszúságát és szélességét az Image J programmal. A statisztikai teszteket a GraphPad Prism szoftverrel végeztük. 
A sejtnyúlványok megjelenítéséhez en-Gal4/ aktin-EGFP és en-Gal4, Df(2R)BSC383/ $s_{h o t}{ }^{s f 2}$, UAS-aktin-EGFP és $e n-G a 14, \mathrm{Df}(2 \mathrm{R}) \mathrm{BSC} 383 /$ shot $^{k a k P 1}$,UAS-aktin-EGFP valamint en-Gal4, Df(2R)BSC383/ shot ${ }^{4 E G C}$, UAS-aktin-EGFP genotípusú embriókat használtunk. A felvételeket VisiScope spinning disc konfokális mikroszkóppal készítettük el.

A MT-ok növekedési ütemének és növekedés irányának mérésére en-Gal4/ EB1EGFP és en-Gal4, Df(2R)BSC383/ shot ${ }^{\text {sf20 }}$, UAS-EB1-EGFP genotípusú embriókat használtunk fel és a felvételeket Olympus CellR mikroszkóppal készítettük el. A kvantitatív paramétereket az ImageJ szoftver segítségével mértük, az adatokat a GraphPad Prism programmal ábrázoltuk.

\section{Immunhisztokémia}

Az embriókat 50\%-os hipóval dekorionizáltuk, majd 4\%-os formaldehidet tartalmazó PBS (137 mM NaCl; 2,68 mM KCl; 10,14 mM Na $2 \mathrm{HPO}_{4} ; 1,76$ mM KH $\mathrm{KO}_{4}$ ) heptán 1:1 arányú elegyében 30 percig fixáltuk. Ezután az embriókat egy sötét színű selyem anyagra pipettáztuk ki és 2 oldalú ragasztóra szedtük fel, aminek a másik oldalát egy petricsészébe ragasztottuk, majd az embriókat PBS-sel fedtük le. Egy tű segítségével mikroszkóp alatt megsértettük az embriót borító vitellin membránt. Az eljárás során a kézzel devitellinizált embriók kiúsztak a PBS-be. Az embriókat az összegyüjtést követően 3-szor 20 percig mostuk PBT-vel (PBS, 0,1\% Triton-X), majd minimum 1 órán át PBT-N-nel (2\% BSA-t, 5\% FCS-t tartalmazó PBT oldat) blokkoltuk, majd $4^{\circ} \mathrm{C}$-on egy éjszakán át elsődleges ellenanyaggal inkubáltuk. A nem kötődött elsődleges ellenanyagot PBT-ben történő háromszori mosással távolítottuk el (3 x 20 perc). A megfelelö, fluoreszcensen jelölt másodlagos ellenanyagokkal (Invitrogene, 1: 600, PBT-N-ben) és egyéb festékekkel egy órán át inkubáluk a mintákat. Az embriókat ismét PBT-ben mostuk háromszor, végül Fluoromount-G mounting mediumban fedtük le. 


\begin{tabular}{|c|c|c|}
\hline $\begin{array}{l}\text { Elsödleges ellenanyag } \\
\text { hígitás, forrás }\end{array}$ & $\begin{array}{l}\text { Másodlagos ellenanyag } \\
\text { (hígitás: 1:600) }\end{array}$ & $\begin{array}{l}\text { Egyéb festék } \\
\text { (higitás: } 1: 20)\end{array}$ \\
\hline $\begin{array}{l}\text { anti-Tubulin (egér) } \\
1: 10, D S H B\end{array}$ & anti-egér Alexa 647 (szamár) & \multirow{5}{*}{$\begin{array}{l}\text { Rodaminnal jelölt falloidin } \\
\text { Alexa } 594\end{array}$} \\
\hline $\begin{array}{l}\text { anti-EGFP (nyúl) } \\
\text { 1:500, Life Technologies }\end{array}$ & anti-nyúl Alexa 488 (csirke) & \\
\hline $\begin{array}{l}\text { anti-Acetilált-tubulin (egér) } \\
\text { 1:1000, Sigma }\end{array}$ & anti-egér Alexa 647 (szamár) & \\
\hline $\begin{array}{l}\text { anti-Fasciclin III (egér) } \\
1: 20, \text { DSHB }\end{array}$ & anti-egér Alexa 647 (szamár) & \\
\hline $\begin{array}{l}\text { anti-Shot-spectrin-repeatek } \\
\text { (tengeri malac) } \\
1: 1000 \text {, ajándék }\end{array}$ & $\begin{array}{l}\text { anti-tengeri malac Alexa } 546 \\
\text { (szamár) }\end{array}$ & \\
\hline
\end{tabular}

2. táblázat. Immunhisztokémiai jelöléshez használt elsödleges, másodlagos ellenanyagok és egyéb festékek listája.

\section{Hámzáródási esszék}

\section{Torzáródási esszé}

A shot génre specifikus dsRNS-t (UAS-RNSi) a háti középvonalra specifikus pnr-

GAL4 meghajtó elem felhasználásával fejeztettük ki vad és shot ${ }^{s f 20}$ null mutáns torban.

\section{$\underline{\text { Sebzáródási esszé }}$}

SGMCA-t (Moesin aktinkötő fehérjével fúzionált GFP) kifejező vad és shot ${ }^{\text {sf20 }}$ null mutáns törzseket szén és agar tartalmú táptalajon petéztettük 30 percig, majd hagytuk az embriókat, hogy a 16. stádiumig fejlődjenek. Az embriókat összegyüjtöttük és háti oldallal felfelé fordítva egyenként sorba rendeztünk és ragasztóval (heptánban oldott kétoldalú ragasztószalag, 3M) bevont tárgylemezre rögzítettük azokat, majd Halocarbon7S (VWR) olajjal lefedtük. A sebzés körülményeit az intézetünkben elérhető XYclone Laser rendszerrel állítottuk be. A rendszer $300 \mathrm{~mW}$ teljesítményü, $1480 \mathrm{~nm}$-es infravörös lézerfényt bocsát ki, amivel az embriókon $30 \mu \mathrm{m}$ sugarú sebeket ejtettünk. A sebzáródást in vivo videomikroszkópiával követtük nyomon. 


\section{FRAP (Fluorescent recovery after photobleaching)}

A FRAP kísérleteket FRAP programmal ellátott Leica SP5 konfokális mikroszkóppal hajtottuk végre. EGFP-jelölt $\beta$-tubulint fejeztettünk ki vad és shot mutáns hámban. A DME sejtek vezető éléhez közel, $2 \mu \mathrm{m}$ széles területet jelöltünk ki. Annak érdekében, hogy meghatározzuk a kezdeti fluoreszcens intenzitást a hámsejtekben 2 másodpercenként 3 felvételt készítettünk. Ezt követően nagy intenzitású 488nm-es lézersugárral világítottuk meg a kijelölt területet 10 másodpercig. Ezután sorozatfelvételt készítettünk 2 másodpercenként 5 percen keresztül. Meghatároztuk a vizsgált terület átlagintenzitásának változását, majd az adatokat normalizáltuk a fotokioltás előtti kezdeti intenzitásra, illetve a sorozatfelvétel közben bekövetkező enyhe mértékü fakulásra. Az így nyert adatokra easyFRAP program segítségével exponenciális egyenletet illesztettünk, és meghatároztuk a fluoreszcencia visszatérés kinetikai paramétereit. A grafikonokat GraphPad Prism program segítségével ábrázoltuk. 


\section{EREDMÉNYEK}

\section{RNS interferencián alapuló funkcióvesztéses szürés}

Tizenhét gént választottunk ki, melyek irodalmi adatok alapján a sejtvázelemek müködését befolyásolják (Anyagok és módszerek, 1. táblázat). A géneket RNS interferencián alapuló funkcióvesztéses vizsgálatnak vetettük alá. A kiválasztott génekre specifikus dsRNSeket szintetizáltunk in vitro transzkripcióval, majd a dsRNS-seket a szincíciális blasztoderma stádiumban lévő embriókba mikroinjektáltuk. A géneket egyedileg, szekvencia-specifikusan csendesítettünk és in vivo fluoreszcens videó mikroszkópiával követtük a háti záródás folyamatát. A géncsnendesítés hatásának vizsgálatához a záródó hám első sejtsorában/ a DME sejtekben EGFP-t kifejező ZASP52 ${ }^{\text {ZCL0432 }}$ protein-csapda vonalat használtuk. A GFP-vel jelölt Zasp52 fehérje a DME sejtek AS felé eső felszínén halmozódik fel, így a háti nyílás körvonala kirajzolódik és alakjának időbeli változása könnyen nyomon követhető. Vad típusú embriókban, miközben a hámlemezek még egymás felé közelednek, a nyílás mindkét végén már zajlik a hámlemezek összekapcsolódása, a „cipzározódás”. A záródás alatt a háti nyílás így mindvégig megtartja jellegzetes lencse alakját (12. ábra A). A tizenhét vizsgált gén közül csupán egynek, a Drosophila Spektraplakint kódoló short stop (shot)-nak a csendesítése okozott abnormális háti záródást. A csendesített embriókban a háti nyílás bezáródott, azonban a záródás menete abnormális volt: a háti nyílás alakja a vad típusra jellemző lencse alak helyett rendellenesen keskeny lett (12. ábra B). A shot ${ }^{s f 20}$ null embriókban a shot gén csendesítésével megegyező abnormális háti záródást tapasztaltunk (12. ábra C).
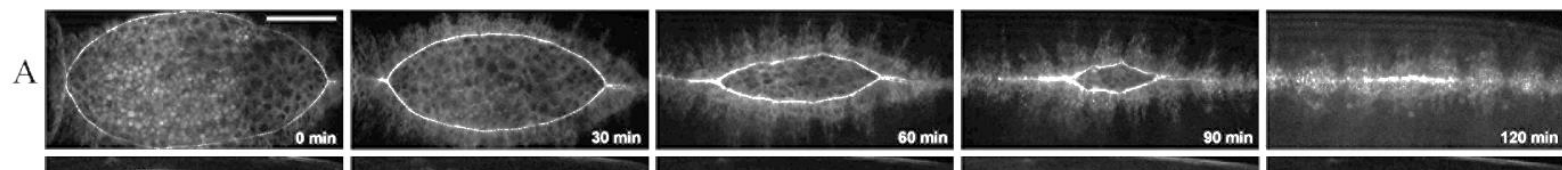

$\mathrm{B}$
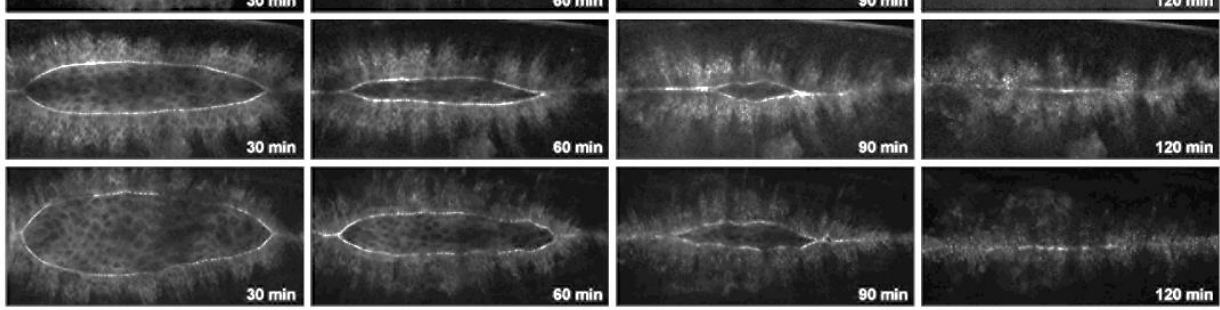

12. ábra. A háti záródás folyamata (A) vad, (B) shot csendesített és $(C)$ shot $^{\text {sf20 }}$ mutáns Drosophila embriókban. A háti nyílás körvonalát a DME sejtekben EGFP-t kifejezö ZASP52 ${ }^{Z C L 0432}$ protein-csapda vonal segitségével tettük láthatóvá. Mérték: 50 um. 
A háti nyílás alakjának kvantitatív leírásához a háti nyílás szélesség $(\mathrm{W})$ / hosszúság $(\mathrm{H})$ arányát használtuk fel. Mivel a mutáns fenotípus a záródás félidejénél volt a legszembetünőbb, a vizsgálathoz a nyílás $30 \mu \mathrm{m}$-es hosszúságnak megfelelő záródási állapotot választottuk ki. A záródásnak ebben a szakaszában a W/H arány a shot dsRNS-sel kezelt és a $s h o t^{s 520}$ mutáns embriókban is jelentősen megnőtt, ami arra utal, hogy a shot gén funkciója szükséges a háti nyílás normális dinamikájú bezárásához (13. ábra A). Az abnormális dinamikájú záródás kvantitatív elemzésére a háti záródás matematikai modelljét használtuk fel (bővebben Irodalmi áttekintés)[13]. Meghatároztuk a háti nyílás szélességének (W) és hosszúságának (H) változását a háti záródás folyamán, majd kiszámoltuk a záródó hám háti középvonal irányába történő elmozdulásának sebességét (v). Az így nyert adatok alapján az empirikus modellt felhasználva meghatároztuk, hogy a záródás sebessége milyen mértékben függ a cipzározódástól $\left(\mathrm{f}_{\mathrm{z}}\right)$.

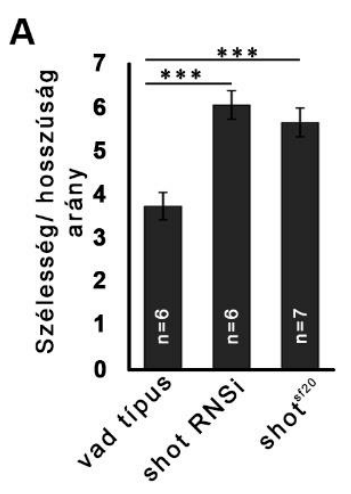

D

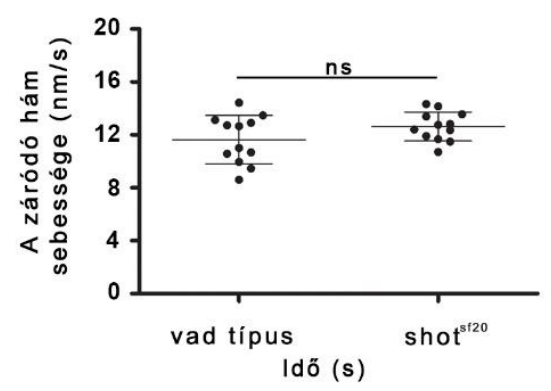

B

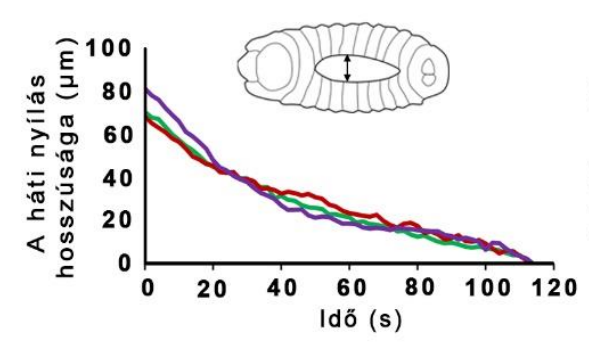

vad típus
E

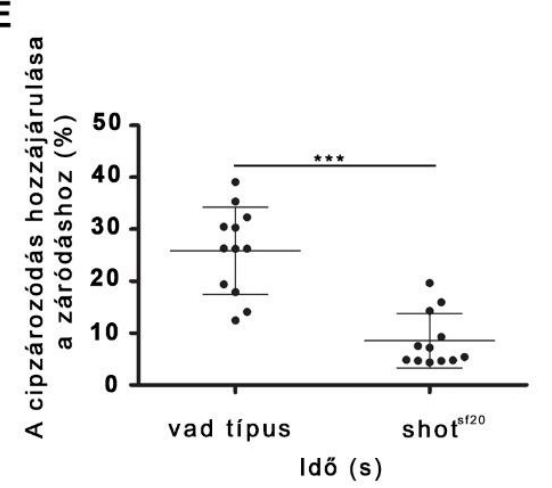

C

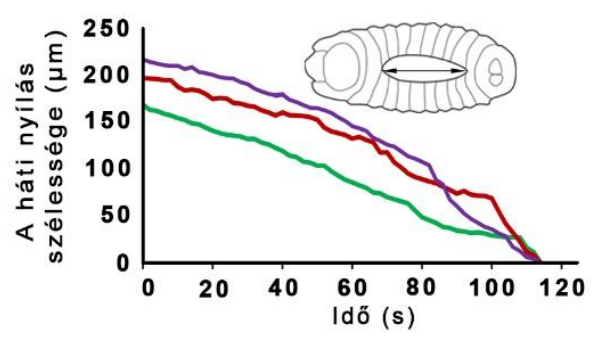

$\mathbf{F}$

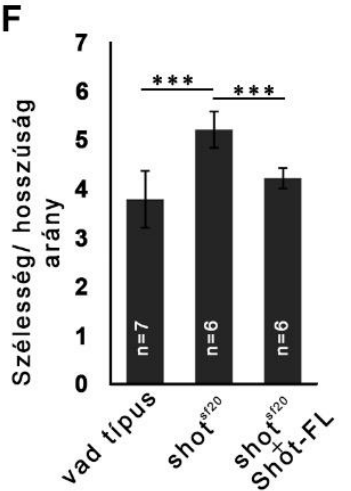

13. ábra. A háti nyílás alakjának kvantitatív leírása. (A) A cipzározódás hatékonysága vad, shot RNSi és shot ${ }^{\text {sf2o }}$ mutáns Drosophila embriókban. A grafikonon a háti nyilás W/H aránya látható $30 \mu m-e s$ hosszúságnak megfelelö záródási állapotban. $(B, C)$ A háti záródás kinetikája egy-egy reprezentatív vad (piros), homozigóta shot mutáns (zöld) és RNSi-val csendesitett shot (kék) embriónál. (B) „Hosszúság” az egymás felé elmozduló hámrétegek távolságát (kettős nyil jelöli) jelöli. (C) „,Szélesség”a cipzározódó végek távilságát (kettös nyil jelöli). (D) A szemben lévö hámlemezek egymás felé közeledésének sebességét mutatja. (E) A cipzározás hozzájárulását mutatja a záródáshoz vad és shot mutáns embriókban. (F) A teljes hosszúságú Shot fehérje menekiti a shot mutáns cipzározódási hibát. Átlag \pm szórás, $t$-próba, ${ }^{* * *} p<0.001$. 
A shot gén mutációja nem befolyásolja a záródás sebességét, ugyanis a shot csendesített és mutáns embriókban a szemben lévő hámlemezek a vad típusú embriókéhoz hasonló sebességgel közeledtek a háti középvonal felé (13. ábra B, D). Vad típusú embriókban $\mathrm{v}=11,63 \pm 1,7 \mathrm{~nm} / \mathrm{sec}$ sebességgel közeledtek a hámlemezek egymás felé, míg a shot mutánsban

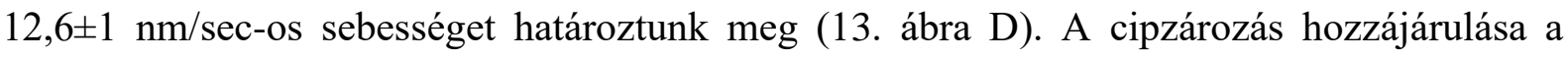
záródáshoz a vad típusban az irodalmi adatoknak megfelelő $\left(\mathrm{f}_{\mathrm{z}}=25,85 \pm 8,2 \%\right)$ értékeknek adódott. Shot mutánsokban a cipzározódás viszont lelassult $\left(\mathrm{f}_{\mathrm{z}}=9,06 \pm 4,92 \%\right)$, ami arra utal, hogy a shot gén a hámlemezek összekapcsolódásában játszik szerepet (13. ábra E).

Menekítési kísérlettel igazoltuk, hogy ez a fenotípus valóban a shot gén müködésének hiányához köthető. Teljes hosszúságú fehérjét (Shot-L(A)-GFP) fejeztettünk ki shot ${ }^{\text {s20 }}$ null mutáns háttéren a hámspecifikus pnr-Gal4 driver segítségével. Ez a fehérjeváltozat képes volt menekíteni a cipzározódási hibát (13. ábra F).

Következő lépésként a shot gén funkcionális konzerváltságát vizsgáltuk meg különbözö hámzáródási folyamatok között. Ehhez a vizsgálathoz az embrionális háti záródással analóg, a normális egyedfejlődés részeként előforduló záródási folyamatban, a felnőtt tor záródása során csendesítettük a shot gént. A shot génre specifikus dsRNS-t a háti középvonalra specifikus pnrGAL4 meghajtó elem felhasználásával fejeztettük ki [93]. A torzáródás a báb metamorfózisa alatt zajlik, melynek során a két imaginális szárnydiszkusz egymás felé mozog és a hát középvonalán összenőve hozza létre a tor egységes kutikuláját [94]. A shot gén szövetspecifikus csendesítése megakadályozta a szárnydiszkuszok fúzióját, ami a felnőtt állatok torán egy jellegzetes bemélyedés kialakulását eredményezte a középvonal mentén (14. ábra A). A shot gén szerepét a mesterségesen létrejött hámhiányok gyógyulásakor sebzáródási esszében vizsgáltuk tovább. Ehhez sikeresen optimalizáltuk a sebzés körülményeit az intézetünkben elérhető XYclone Laser rendszerrel vad típusú embriókon. A kísérlet során Moesin aktinkötő fehérjével fúzionált GFP-t (SGMCA) fejeztettünk ki vad és $s h o t^{s f 20}$ null mutáns embriókban és $30 \mu \mathrm{m}$ sugarú sebeket ejtettünk a hámon, majd in vivo videomikroszkópiával követtük nyomon a sebzáródást. A shot ${ }^{\mathrm{s} 20}$ mutáns embriókban a seb bezáródott, azonban jelentősen lasabban a vad típushoz képest (14. ábra B). 
A

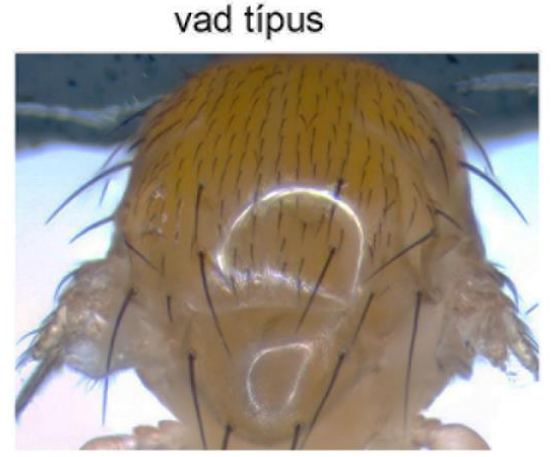

shot RNSi

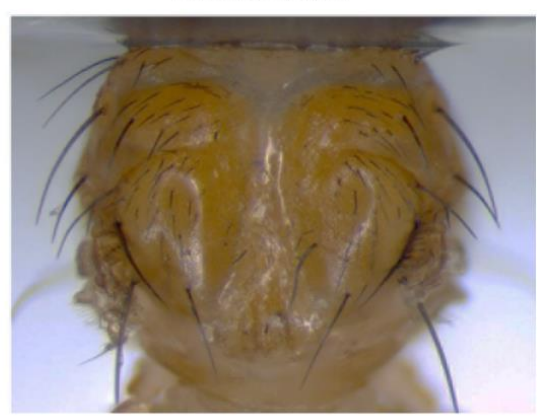

B
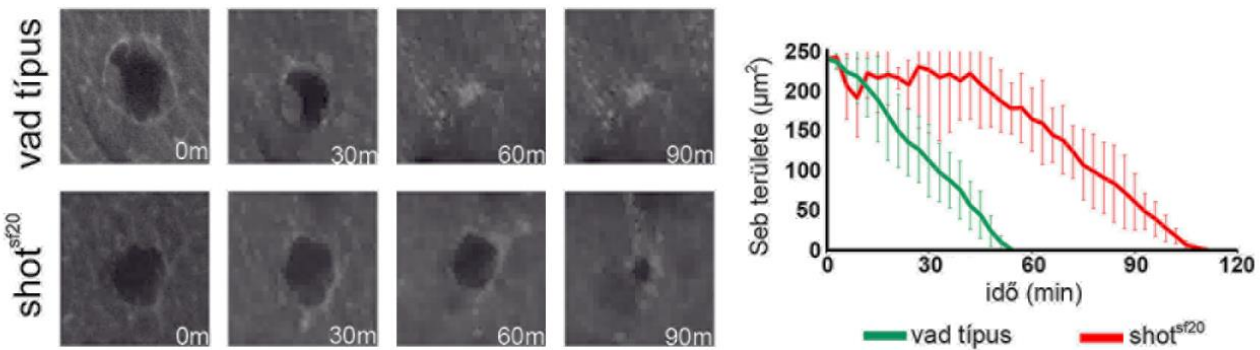

14. ábra. A shot gén funkcionális konzerváltsága különbözö hámzáródási folyamatok között. (A) A shot gén szövetspecifikus csendesitése torzáródási hibát mutat összehasonlitva egy vad típusú, tökéletesen záródott torral. (B) Shot ${ }^{\mathrm{s} 20}$ null mutáns hámon ejtett 30 um sugarú sebek jelentösen lasabban záródnak be a vad típushoz képest. Mérték $10 \mu \mathrm{m}$. 


\section{Shot ${ }^{A E G C}$ mutáns allél létrehozása CRISPR/Cas9 módszerrel}

Mivel a $\operatorname{shot}^{\mathrm{sf2}}$ null mutánsok háti záródásának hibái a MT-depolimerizáló droggal kezelt embriók abnormális záródására emlékeztetnek, ezért azt valószínüsítettük, hogy a Shot fehérje a MT-váz szabályozásán keresztül hat ebben a folyamatban. Ennek vizsgálatára olyan funkcióvesztéses shot mutáns allél elöállítását terveztük CRISPR/Cas9 (clustered regularly interspaced short palindromic repeate) genomszerkesztési módszer segítségével, amelyből deletáljuk a shot gén MT-kötésért felelős doménjeit.

A CRISPR-Cas9 rendszer fő komponense a Cas9 endonukleáz, amely komplexet képez az ún. egyszálú irányító (single guide, sg) vagy kiméra (chimeric, chi) RNS-molekulával. A kiméra RNS két elemből tevődik össze: egy kb. 20 nukleotid nagyságú, a cél DNS-szakasszal komplementer crRNS-molekulából (CRISPR-RNS), illetve az azzal kölcsönható váz transzaktiváló crRNS-molekulából (tracrRNS), ami elősegíti a Cas9 fehérje célba juttatását és a DNS szálak hasítását [95]. A célszekvencia felismerése és hasítása szekvencia komplementaritást igényel a crRNS és a DNS között, és egy PAM (protospacer-adjacent motif) motívumot a célszekvencia 3' végén [96].

Számos CRISPR/Cas9 alapú genomszerkesztési módszer közül mi azt választottuk, amelyben a Cas9 ivarvonalspecifikus kifejeződését egy genomba inszertált transzgénen a vasa gén promotere hajtja meg [97]. A rendszer másik elemét, a chiRNS-eket pedig a shot génnel komplementer specifikusan terveztük meg. A shot gén Gas2 és EF-hand doménjeit körülvevő genomi régióra két szekvenciaspecifikus, 20 nukleotid hosszúságú oligonukleotidot terveztünk (lásd Anyagok és módszerek). A megszintetizált oligonukleotidokat expressziós vektorba klónoztuk, amit baktériumból tisztítottk, és szekvenálással ellenőriztük a chiRNS-t kódoló oligonukleotidok sikeres beépülését a vektorba.

A deléció előállításához két különböző chiRNS-t kifejező plazmidot injektáltunk vasaCas9 embriókba. Mivel ilyen esetben a Cas9 két helyen hoz létre a DNS-en kettős szálú törést, a két hasítási hely közötti nagyobb DNS szakasz deletálódik (15. ábra). A kikelt hímeket (G0) $\mathrm{w}^{+}$; SM6b/Sco nőstényekkel kereszteztük, majd a hímekben egylegyes PCR-rel vizsgáltuk a deléció létrejöttét. Hét tesztelt G0 hím közül három esetben sikerült kimutatni, hogy hordozzák a várt méretü deléciós allélt. Ezek a G0 hímek azonban mozaikosak, testüknek csak azok a sejtjei hordozzák a mutáns allélt, amelyek elődeiben a deléció kialakult. Továbbörökíthető deléciós allél izolálásához arra van szükség, hogy a deléció az ivarvonal sejtjeiben jöjjön létre. A három pozitív hím utódaival ezért komplemntációs analízist hajtottunk végre a shot lókuszt 
lefedő, nagyméretü $D f(2 R) B C 383$ deficiencia felhasználásával. Ez a 184 kbp-os deficiencia teljesen eltávolítja a shot gént, így nem komplementálja a shot null mutáns allélek okozta letális fenotípust. Feltételeztük, hogy a $D f(2 R) B C 383$ deficiencia felett a shot gén MT-kötő aktivitásának elvesztése szintén letális. A három G0 hím 230 utódját komplementációs tesztben megvizsgálva három esetben nem tapasztaltuk a letális fenotípus komplementációját. Ezeket a legyeket felhasználva törzseket alapítottunk, és az újonnan izolált shot allélt $s h o t^{\triangle E G C}$-nek neveztük el. Az újonnan létrehozott, stabilan balanszírozott shot mutáns törzsekben nem jelentek meg homozigóta mutáns állatok, ami azt bizonyítja, hogy a shot MT-kötő aktivitása esszenciális a muslica életképessége szempontjából. A kapott deléció mérete az elvárt 1895 bázispár volt, amit szekvenálással is igazoltunk. A deléció magába foglalta a Gas2 és az EFhand doméneket kódoló genomi szakaszt (15. ábra). A deléció 6 exont (758 nukleotid) távolított el és a következő négy aminosav után egy frame-shift mutációt okozott a shot gén transzkriptumában.

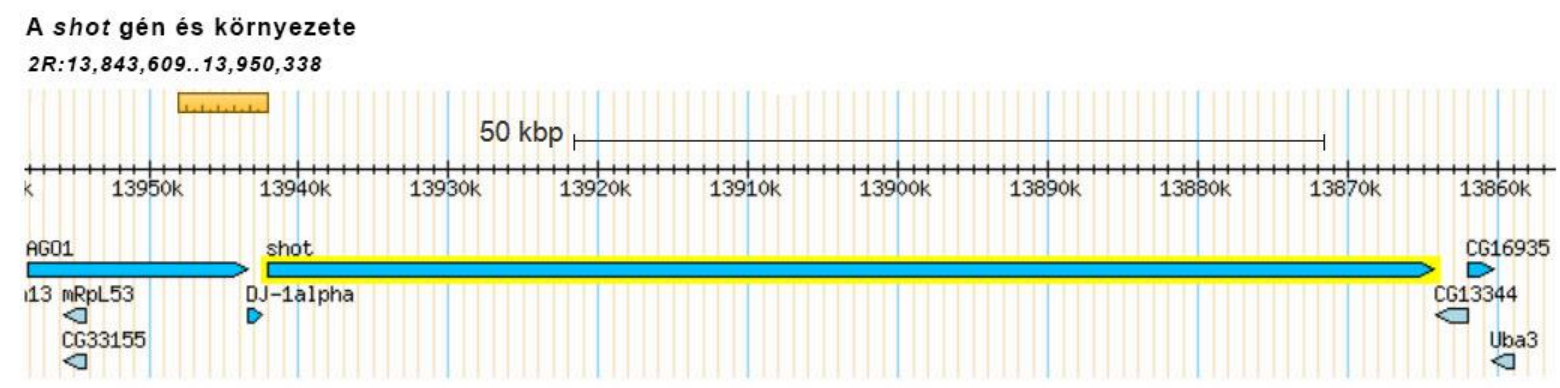

A Shot-RE transzkriptum

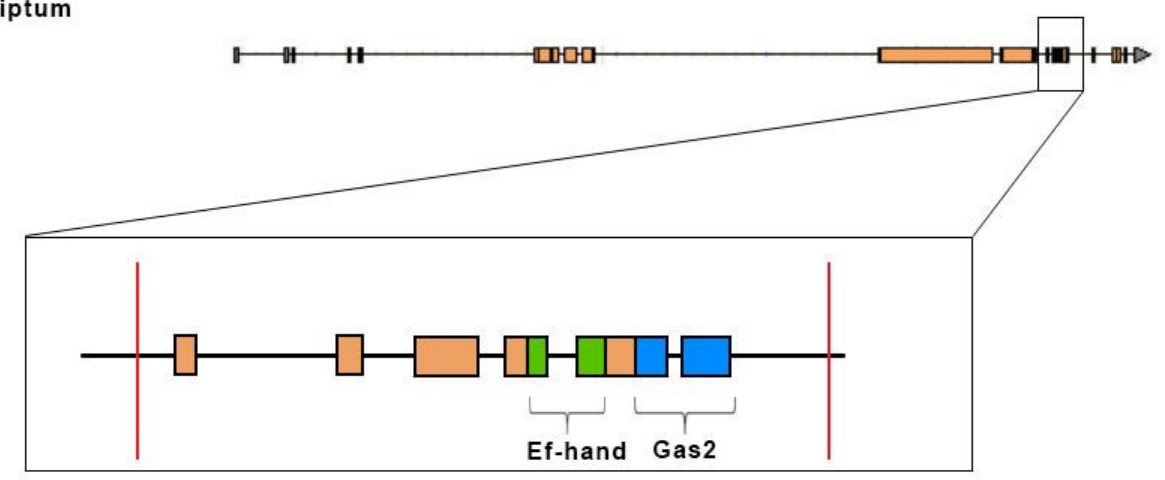

A shot $\triangle E G C$

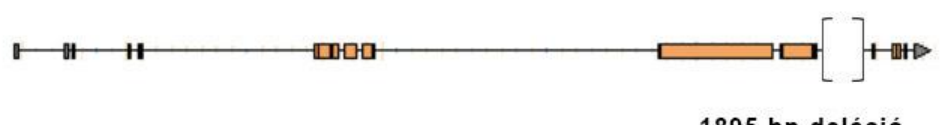

15. ábra. A shot ${ }^{A E G C}$ allél létrehozásának vázlatos ábrája. A teljes hosszúságú Shot fehérje és a MTkötésért felelös EF-hand GAS2 doméneket kódoló exonok kinagyitva a fekete téglalapban. Piros függöleges vonallal az oligonukleotidok elhelyezkedése a génen. Zöld színnel az EF-hand kódoló rész, kékkel a Gas2 kódoló rész látható. 
A csonkolt fehérje kifejeződését immunfestéssel igazoltuk a shot ${ }^{4 E G C}$ mutáns embriókban a spectrin repeat-ek ellen termelt poliklonális ellenanyaggal (16. ábra D).
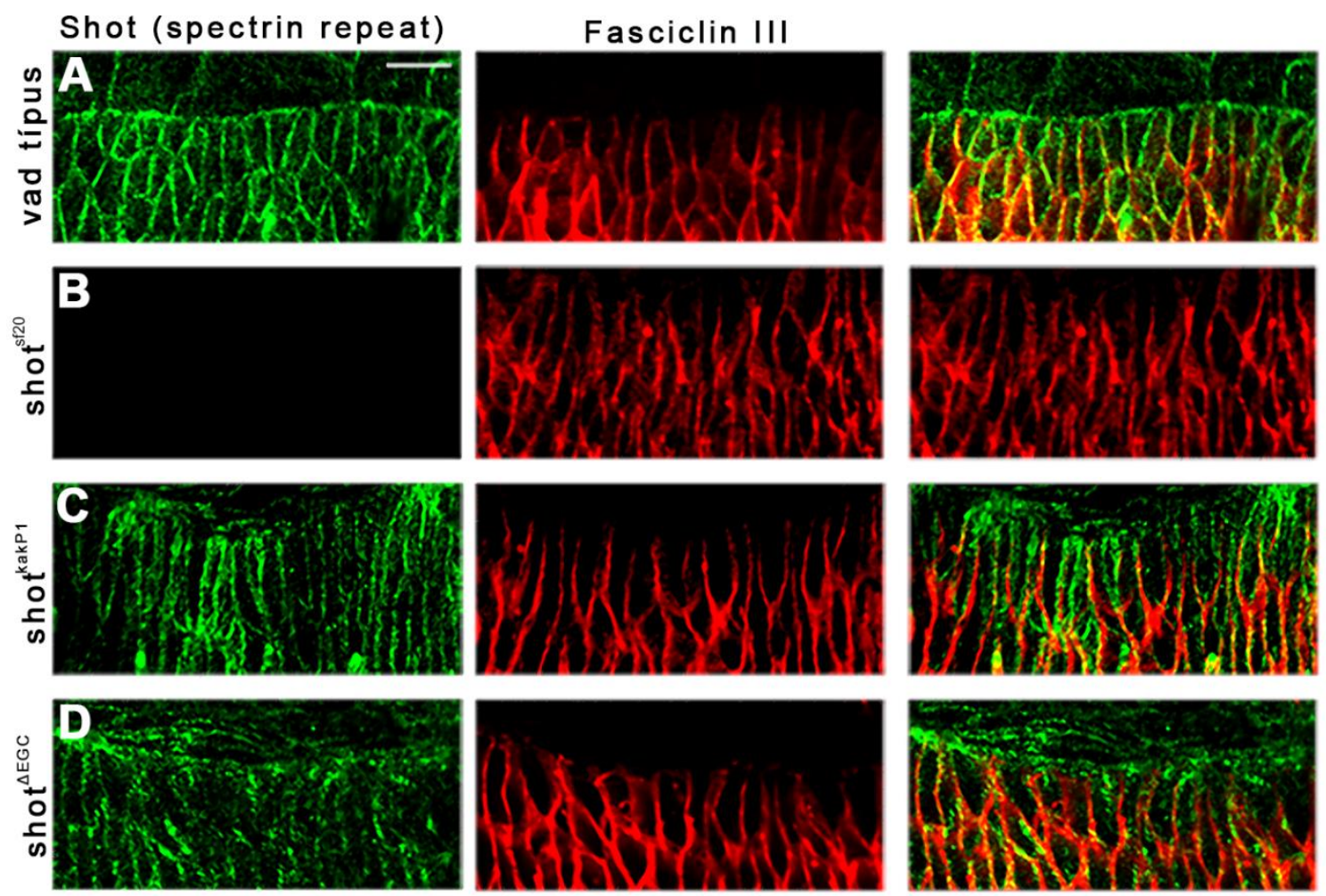

16. ábra. Az endogén Shot fehérje expressziója különbözö mutáns DME sejtekben. (A-D) DME sejtek immunfluoreszcens jelölése vad (A), shot ${ }^{\mathrm{s} 20}(B)$, shot ${ }^{k a k P 1}(C)$ és shot ${ }^{4 E G C}(D)$ mutáns embriókban. A spectrin repeat-ek ellen termelt Shot ellenanyag felismeri a különbözö Shot izoformákat shot ${ }^{\triangle E G C}$ és shot $^{k a k P 1}$ mutáns hámban (zöld). A Shot fehérje nem mutatható ki shot ${ }^{\text {s20 }}$ null mutáns hámban. A FasciclinIII festés kijelöli a hámsejtek körvonalát (piros). Mérték $10 \mu m$. 


\section{A Shot fehérje aktin-MT keresztkötő aktivitása révén szabályozza a cipzározódást}

A Shot fehérje MT-kötő aktivitásának szerepét a háti záródásban a laborunkban létrehozott shot ${ }^{\triangle E G C}$ mutáns allél, valamint egy sor csonkolt doménszerkezetű transzgén segítségével tártuk fel. A shot ${ }^{\triangle E G C}$ embriókban a shot null mutáns embriókhoz hasonlóan a cipzározódás lassú volt, ami arra utal, hogy a shot MT-kötő aktivitása szükséges a normális dinamikájú cipzározódáshoz (17. ábra A, B). A Shot fehérje MT-kötő aktivitását három funkcionális doménje, az EF-hand, a Gas2 és a CTD biztosítja. Ezen funkcionális domének szerepének pontosabb megértéséhez olyan transzgéneket fejeztettünk ki shot mutáns hámban, melyekből 1-1 funkcionális domén hiányzott. A Shot $\Delta$ EF-hand-GFP és a Shot $\Delta C$-tail-GFP transzgenikus konstrukciók kifejeztetése menekíti a cipzározódási hibát, a Shot $\Delta$ Gas2-GFP transzgén kifejeztetése viszont nem menekítette a mutáns fenotípust (17. ábra C). Ezek az eredmények arra utalnak, hogy a Gas2 MT-kötő domén szükséges a normális dinamikájú háti záródáshoz

A shot ${ }^{k a k P 1}$ mutáns allél és a Shot $\triangle \mathrm{CH} 1-\mathrm{GFP}$ transzgén felhasználásával vizsgáltuk meg, hogy szükség van-e a Shot fehérje aktin-kötő aktivitására a háti záródás alatt. A shot ${ }^{k a k P 1}$ allélról aktin kötésre képtelen fehérjék képződnek és a shot ${ }^{k a k P 1}$ mutáns embriókban a null mutáns embriókhoz hasonlóan a cipzározódás lassú volt (17. ábra A, B). Ezzel összhangban, az aktinkötő domént nem tartalmazó Shot $\Delta \mathrm{CH} 1-\mathrm{GFP}$ transzgén nem volt képes menekíteni a cipzározódási hibát (17. ábra C). Ezek az eredmények azt bizonyítják, hogy a shot aktinkötő képessége is nélkülözhetetlen a cipzározódáshoz.

A mutánsanalízis és a menekítési kísérletek együttesen azt jelzik, hogy a Drosophila Shot fehérje kölcsönhatása a Gas2 doménen keresztül a MT-vázzal, valamint kötődése az aktin hálózathoz egyaránt esszenciális a cipzározódáshoz. Ezzel az eredménnyel öszhangban van a Shot $\Delta \mathrm{CH} 1 \Delta \mathrm{Gas} 2-\mathrm{GFP}$ fehérjével végrehajtott menekítési kísérelet. Ez a csonkolt fehérjeváltozat sem aktinkötő, sem MT-kötő képességel nem rendelkezik és nem volt képes menekíteni a shot gén hiányát.

A vad dinamikájú cipzározódáshoz a CH1 és a Gas2 domének kölcsönhatása az aktinnal és MT-okkal történhet egymástól függetlenül. Elképzelhető azonban, hogy a Shot molekula aktin- és MT-kötő doménjeivel egyidejüleg kapcsolódik mindkét sejtvázelemhez, és keresztköti őket. Ezért megvizsgáltuk a shot ${ }^{A E C G} /$ shot $^{k a k P 1}$ heteroallélikus kombinációt hordozó embriók háti záródását. Ezekben az embriókban a Shot fehérje vagy a $\mathrm{CH} 1$ aktinkötő domént vagy a $\mathrm{C}$ - 
terminális régiót tartalmazza, de sohasem képződik olyan fehérje, amelynek egyidejüleg lenne aktinkötő és MT-kötő aktivitása is. A shot ${ }^{A E C G} / s h o t^{k a k P 1}$ genotípusú embriók a null mutánssal megegyező cipzározódási hibát mutatnak, ami azt jelzi, hogy a Shot aktinkötő CH1, és a MTkötő Gas2 doménjére egy fehérjemolekulán belül van szükség a normális dinamikájú háti záródáshoz (17. ábra $\mathrm{A}, \mathrm{B})$.

Összefoglalva, eredményeink arra utalnak, hogy a Shot fehérje az aktin- és a MT-váz keresztkötésével irányítja a háti záródás cipzározódási fázisát.

A
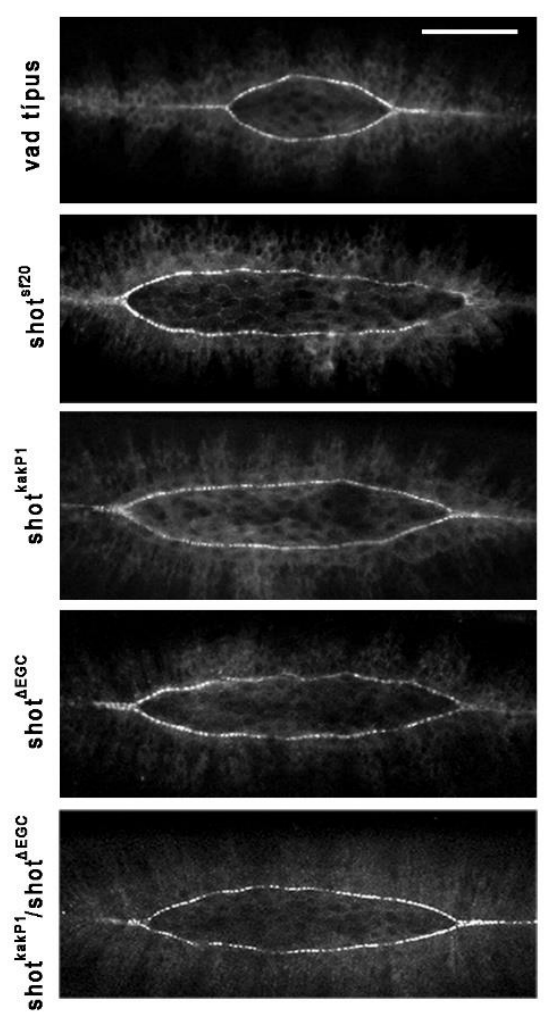

B

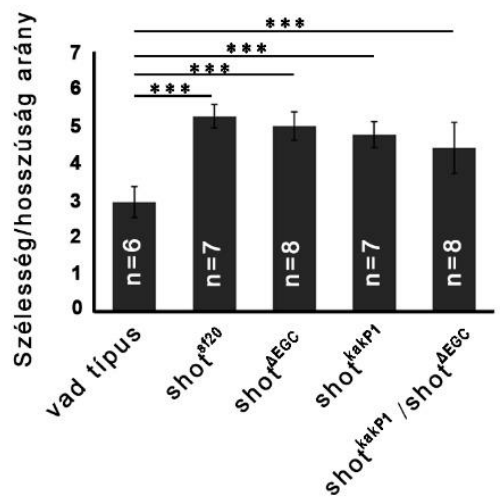

C

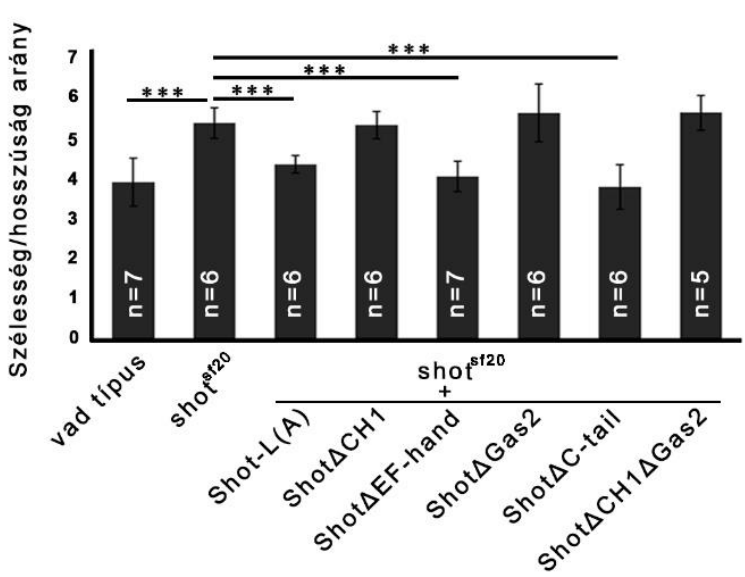

17. ábra. A Shot MT-kötő ás aktinkötő aktivitása együttesen szükséges a cipzározódáshoz. (A) Cipzározódási fenotípus shot ${ }^{s 20}$, shot ${ }^{k a k P 1}$, shot ${ }^{4 E G C}$ és shot ${ }^{4 E G C} /$ shot ${ }^{k a k P 1}$ mutáns embriókban $30 \mu$ m-es szélességnek megfelelö záródási állapotban. Mérték $50 \mu \mathrm{m}$. (B) A háti nyílás W/ H aránya különbözö shot mutánsokban. (C) A háti nyilás W/ H aránya különbözö transzgénekkel végzett menekitési kisérletek során. A csonkolt doménszerkezetü Shot fehérjeváltozatokat shot ${ }^{\text {sf2 }}$ nul mutáns háttéren, pnr-Gal4 driver segitségével fejeztettük ki. Átlag \pm szórás, ANOVA teszt, *** p<0.001. (A felvételek megtekinthetök: http://movie.biologists.com/video/10.1242/jcs.193003/video-1) 


\section{A Shot fehérje a hámsejtek MT-vázának elrendeződését szabályozza}

A $s h o t^{s f 20}$ mutáns záródási fenotípusa megegyezik a MT-ok teljes hiányakor jelentkező fenotípussal, ami arra utal, hogy a shot gén funkciója szükséges a hámsejtek MT-ainak müködéséhez. A shot mutáns hámsejtek MT-vázának elrendeződését immunfestéssel vizsgáltuk meg. A háti záródás alatt a mutáns embriók MT-ai a hámsejtekben a vad típushoz hasonlóan párhuzamos kötegekbe rendeződnek, a DME sejtek sejtnyúlványaiba benövő dinamikus MT-ok azonban abnormálisak voltak. A vad típusra jellemző rövid, egyenes MT-ok helyett a mutáns hámsejtek sejtnyúlványaiban rendkívül hosszú, meghajlott MT-ok jelentek meg (18. ábra A, B).
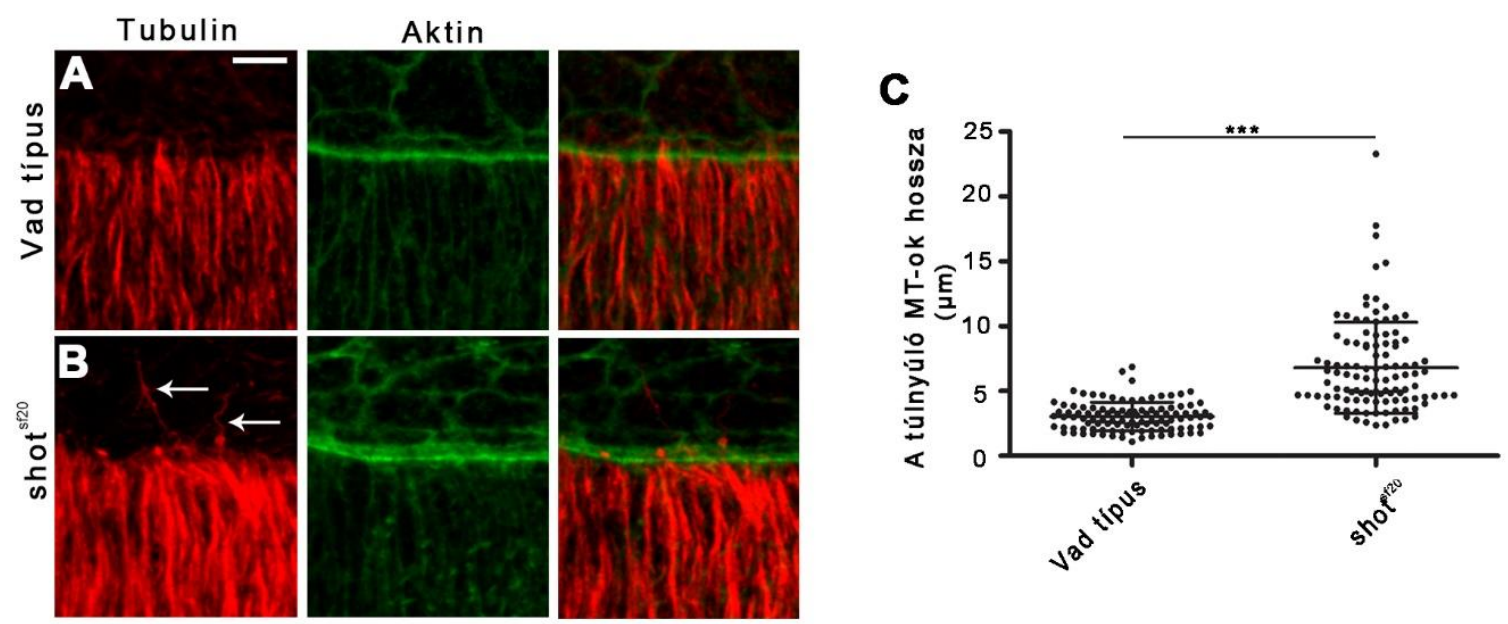

18. ábra. Rendellenes MT-ok a shot ${ }^{\mathrm{f} 20}$ mutáns DME sejtekben. (A, B) Vad típusú és shot ${ }^{\mathrm{s} 20}$ mutáns embriók immunfluoreszcens jelölése a háti záródás alatt. A tubulin festés a MT-okat mutatja (piros), az aktint phalloidinnel tettük láthatóvá (zöld). A fehér nyilak a rendellenesen hosszú és meghajlott MTokat jelölik a vezetö élben. Mérték $10 \mu \mathrm{m}$. (C) A túlnyúló MT-ok kvanitativ elemzése vad és shot ${ }^{\text {s } 20}$ mutáns Tubulin-EGFP-t kifejezö DME sejtekben. Átlag \pm szórás, t-próba, ${ }^{* * *} p<0.001$.

A részletesebb elemzés érdekében, Tubulin-EGFP-t kifejező hámsejteket filmeztünk le, így közvetlenül nyomon tudtuk követni a MT-váz felépítését. A DME sejtek sejttestjében a MT-ok párhuzamos kötegekben helyezkedtek el, azonban a shot mutánsban a kötegek gyakran hirtelen meghajlottak. (19. ábra B, B'). A shot mutáns DME sejtek vezető élében találtunk sejtnyúlványokba belépő rendellenes, meghajlott MT-okat, továbbá a vad típustól eltérően, a shot mutáns DME sejtek laterális felszínéről kinyúló abnormális MT-okat is megfigyeltünk. (19. ábra C, C'). A túlnyúló MT fenotípus kvantitatív elemzése kimutatta, hogy a mutáns DME sejtek nyúlványaiban a MT-ok hoszabbra nőnek $(6.8 \pm 3.5 \mu \mathrm{m}, \mathrm{n}=109)$, mint a vad típusú sejtekben $(3.8 \pm 1.1 \mu \mathrm{m}, \mathrm{n}=108)$ (19. ábra C). Ezek a megfigyelések összefoglalva arra utalnak, hogy a Shot fehérje a MT-váz szabályozásán keresztül hat a háti záródásra. 


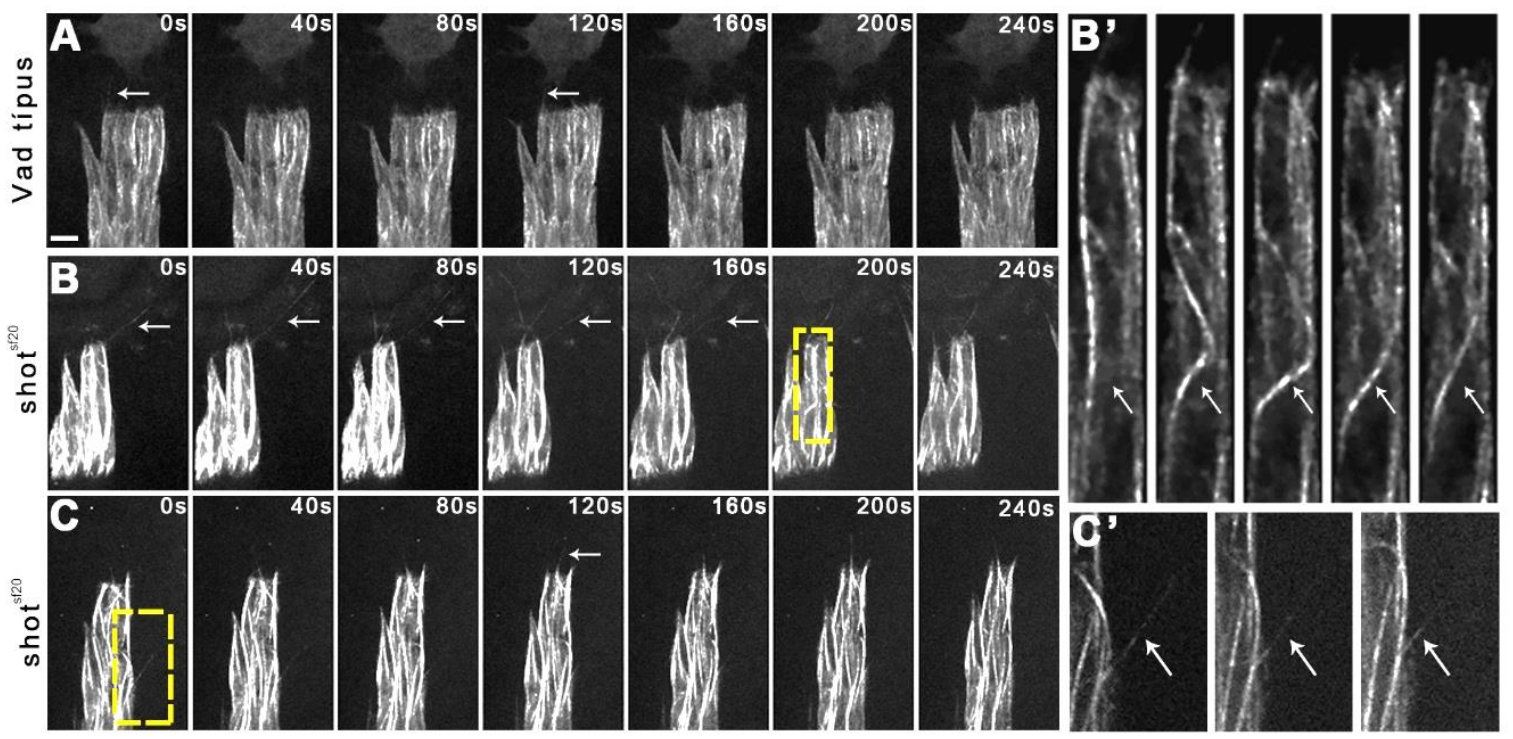

19. ábra. Abnormális MT-ok shot ${ }^{\mathrm{s} 20}$ mutáns DME sejtekben. $(A, B, C)$ Tubulin-EGFP-t kifejezö DME sejtek vad típusú és shot ${ }^{520}$ mutáns embriókban. A fehér nyilak a sejtnyúlványokba belenövö MT-okat mutatják. A bekeretezett régiók (sárga) kinagyitva mutatják a meggörbült MT-okat a sejttestben (B') és a hámsejtek laterális felszinéröl kinyúló MT-okat (C'). Mérték $5 \mu \mathrm{m}$. (A felvételek megtekinthetők: http://movie.biologists.com/video/10.1242/jcs.193003/video-2) 


\section{A Shot fehérje a MT-okat stabilizálja}

A mutáns hámsejtekben megfigyelhető MT-túlnövéses fenotípus hátterében a MT-ok megváltozott dinamikája állhat. Gyorsabb polimerizásiós sebesség vagy az alacsonyabb katasztrófa frekvencia is olyan MT-okhoz vezethet, melyek miután elérték a sejtkérget tovább nőnek és túlnyúlnak a sejtkérgen vagy visszahajlanak. A MT stabilitását az $\alpha$-tubulin Cterminális acetilációját megjelenítve tanulmányoztuk, mely főleg a hosszú életidejü, stabil MTon található meg. A korábbi megfigyelésekkel összhangban az acetilált tubulin a stabil, párhuzamos kötegekbe rendeződött MT-okon jelenik meg a vad DME sejtek sejttestjeiben és ugyanezt a mintázatot figyeltük meg $\operatorname{shot}^{s f 20}$ mutánsban is (20. ábra). A rendellenes MT-okat viszont nem tudtuk kimutatni anti-acetil-tubulin ellenanyaggal, vagyis a Shot fehérje a dinamikus MT-okat szabályozza.
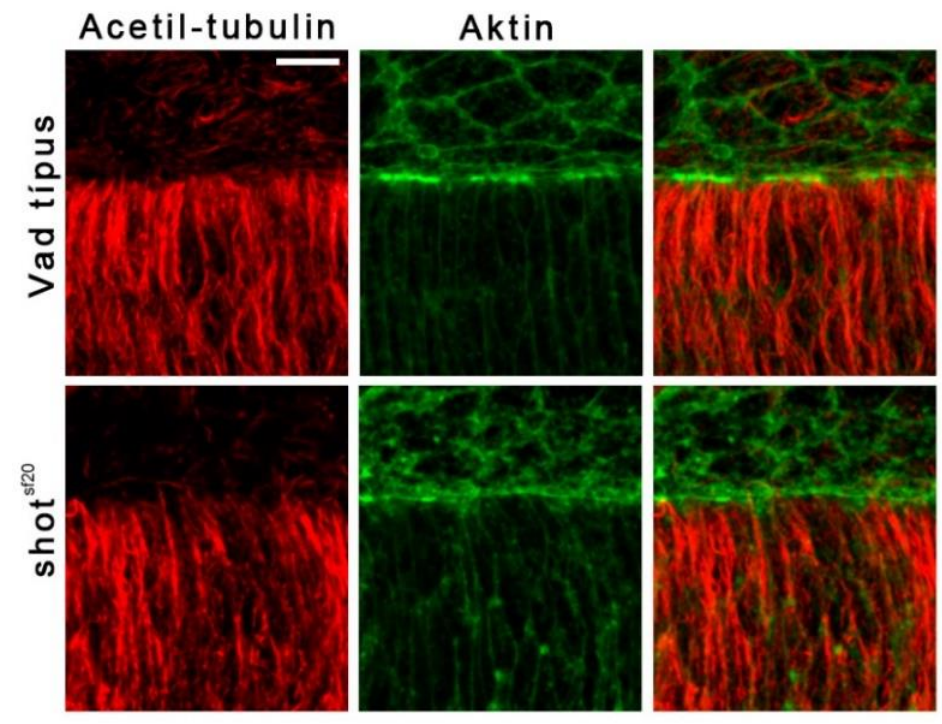

20. ábra. Vad típusú és shot ${ }^{\mathrm{s} 20}$ mutáns embriók immun-fluoreszcens jelölése a háti záródás alatt. Az acetil-tubulin ellenanyaggal a stabilizált MT-okat jelöltük meg (piros), az aktint phalloidinnel tettük láthatóvá (zöld). A shot ${ }^{s 20}$ mutánsban a rendellenes $M T$ okat nem tudtuk kimutatni anti acetiltubulin ellenanyaggal, vagyis a Shot fehérje a dinamikus MT-okat szabályozza. Mérték: $10 \mu \mathrm{m}$.

A MT-ok dinamikus tulajdonságait FRAP analízissel vizsgáltuk tovább. Tubulin-EGFPt fejeztettünk ki vad és shot mutáns hámban, majd a vezető élhez közel, $2 \mu \mathrm{m}$ széles területet nagy intenzitású $488 \mathrm{~nm}$-es lézersugárral világítottunk meg, így kifakítottuk a területen belül található EGFP- $\beta$-tubulin molekulák fluoreszcenciáját. Ezt követően sorozatfelvételt készítettünk a kifakított területről (21. ábra A). A fakított EGFP- $\beta$-Tubulin molekulákat tartalmazó MT-ok lebomlanak, míg a nem fakított EGFP- $\beta$-Tubulin molekulák új MT-okba épülnek be, amik benőnek a fakított területre, így a vizsgált területen ismét floureszcensen jelölt MT-ok figyelhetők meg. A mérés információt ad a fluoreszcens jel visszatérésének sebességéről $\left(\mathrm{t}_{1 / 2}\right)$, melyet a kívülről érkező nem fakított tubulin molekulák beépülése eredményez a MTokba, ezeknek a molekuláknak a hányadáról (mobilis frakció) (21. ábra B-D), valamint a 
kijelölt területen stabilan megtalálható molekulákról (immobilis frakció). A vad és a mutáns sejtekben a fluoreszcens jel visszatérése nem volt teljes mértékü, nem érte el a kezdeti fluoreszcencia jel intenzitását, ami a fakított területen belül stabilan megtalálható immobilis molekulák okoztak. A vad és shot mutáns hámban viszont hasonló mobilis frakciót mértünk (21. ábra C). Ez alátámasztja eddigi eredményeinket, miszerint a Shot fehérje nem befolyásolja a már stabilizált MT-okat, ellenben a dinamikus MT-okra van hatással. A mutáns sejtekben a

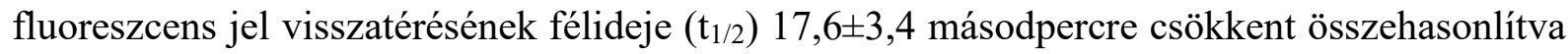
a vad sejtekkel, ahol 40,5 $\pm 12,1$ másodpercet határoztunk meg. Eredményeink megerősítik a feltételezésünket, miszerint a mutáns sejtekben az EGFP-tubulin gyorsabban cserélődik ki a MT-ok és a citoszol között (21. ábra D). A shot mutáns sejtekben a MT-ok tehát dinamikusabbak, ami arra utal, hogy a Shot fehérje a MT-ok dinamikus tulajdonságainak szabályozásán keresztül hat a DME sejtek MT- vázának elrendeződésére.
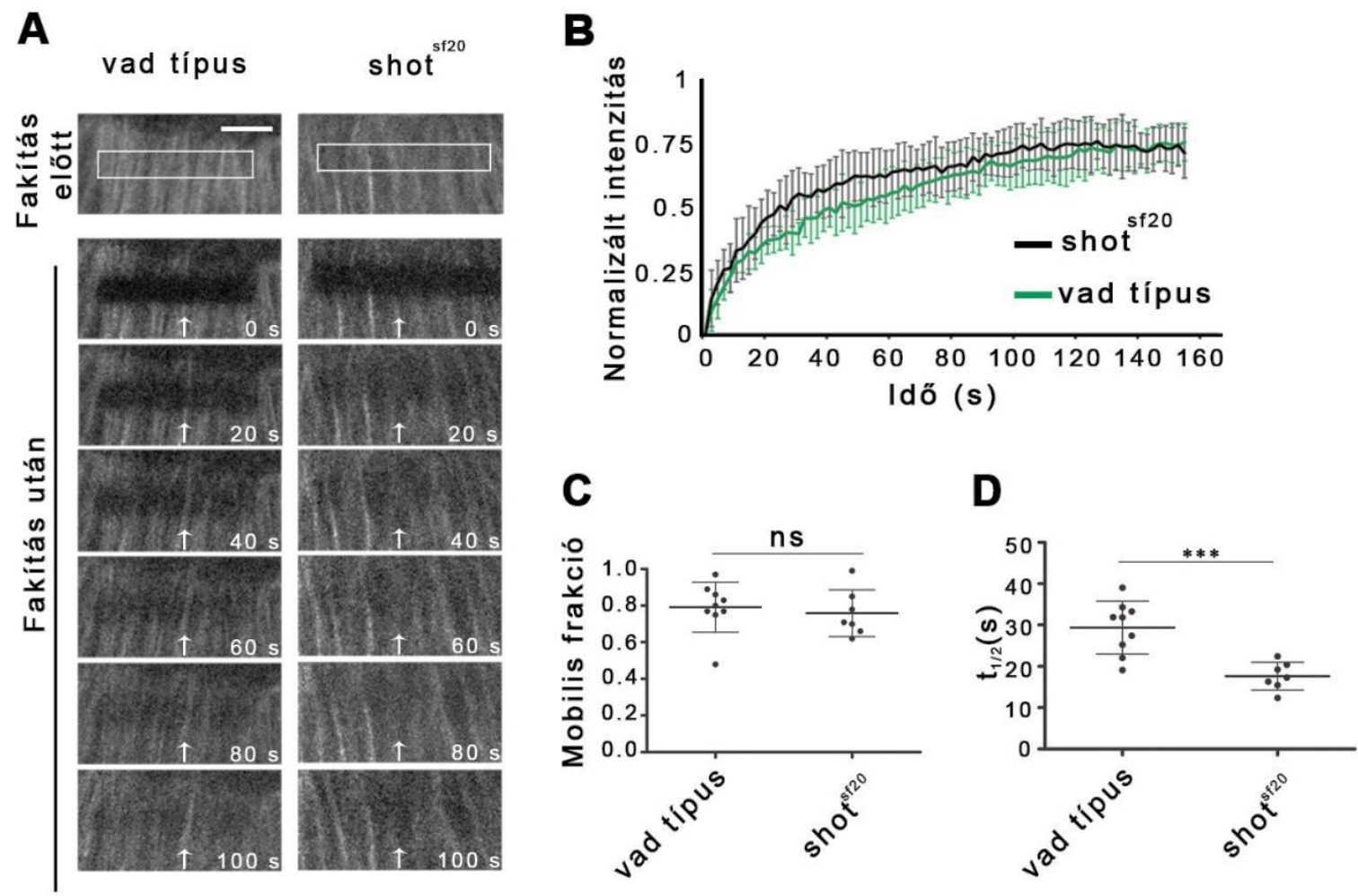

21. ábra. A Shot fehérje a dinamikus MT-okat szabályozza a DME sejtekben. (A) Sorozatfelvétel a tubulin-EGFP-t kifejezö hámsejtek fluoreszcenciájának kioltása elött és utána. A körülhatárolt területet (fehér keret) nagy intetnzitású 488nm-es lézersugárral világitottunk meg. Mérték 5 um. (B) A tubulinEGFP fluoreszcencia jel visszatérésének görbéje vad (zöld, $n=9)$ és shot ${ }^{s f 20}$ mutáns (fekete, $\left.n=7\right)$ DME sejtekben. (C, D) Grafikonok a fluoreszcecia jel visszatérésének sebességét ( $\left.t_{1 / 2}\right)$, és a Tubulin-EGFP molekulák mobilis hányadát (mobilis frakció) mutatják vad és shot ${ }^{\mathrm{s} 20}$ mutáns sejtekben. Shot ${ }^{\mathrm{s} 20}$ mutáns sejtekben a $t_{1 / 2}$ lecsökkent, míg a Tubulin-EGFP mobilis frakciója jelentös különbséget nem mutatott. 
A Tubulin-EGFP FRAP kísérletben tapasztalt gyorsabb kicserélődését okozhatja a mikrotubulusok megváltozott “+” vég dinamikája, például a polimerizáció sebessége vagy annak időtartama. Megvizsgáltuk a Shot fehérje funkcióját a MT-ok növekedésének szabályozásában úgy, hogy fluoreszcensen megjelölt EB1-GFP markerfehérjét követtünk nyomon in vivo filmezéssel. Az EB1 fehérje a MT-ok növekvő “+” végéhez kötődik és így lehetővé válik a MT-ok növekedésének közvetlen mérése.

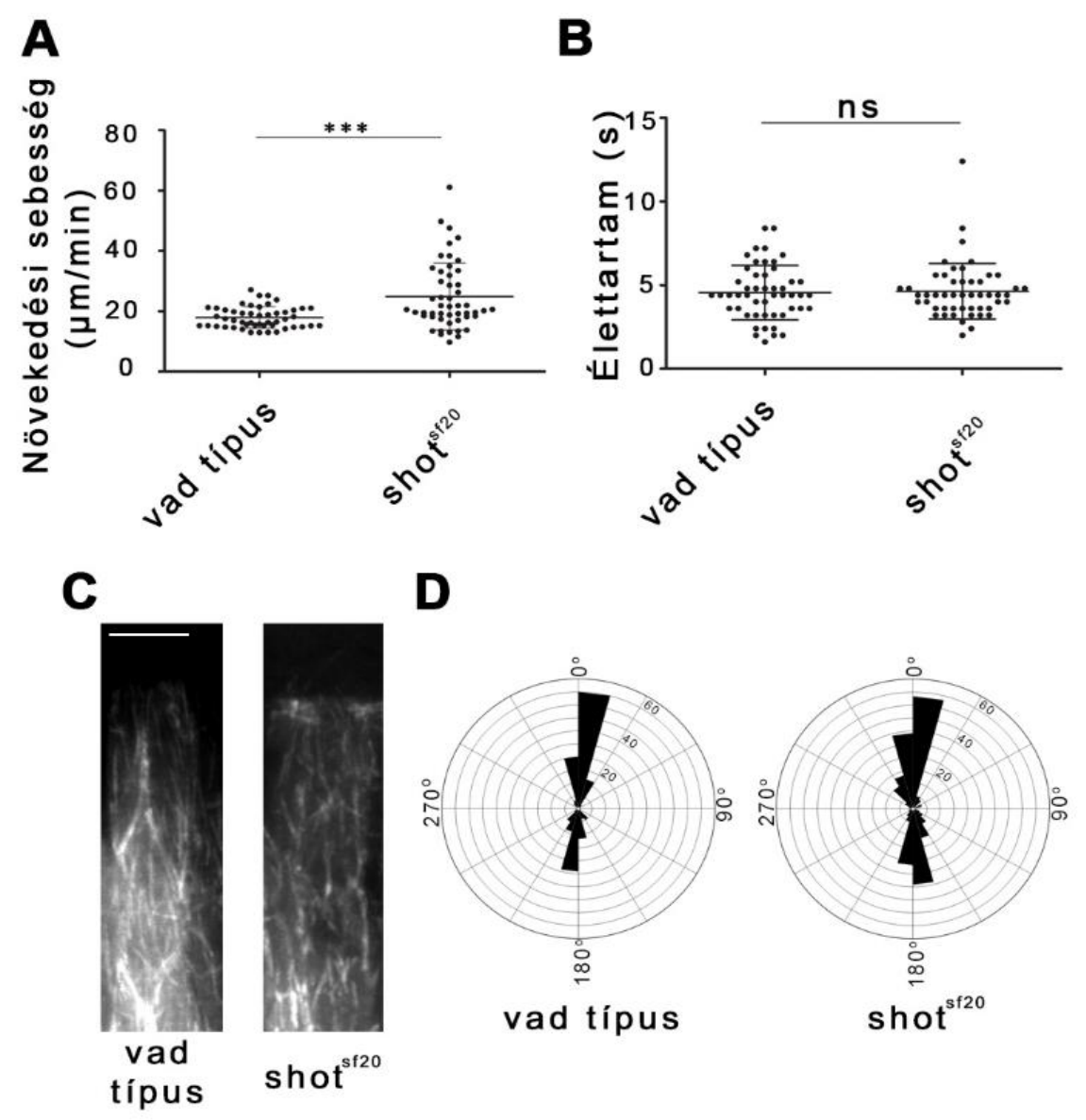

22. ábra. A Shot fehérje a dinamikus MT-okat szabályozza a DME sejtekben. (A, B) Grafikonok a MT növekedési sebességét és a MT-ok növekedésének idötartamát mutatják vad és shot ${ }^{s 520}$ mutáns sejtekben. A mutáns hámsejtekben a MT növekedési sebessége jelentösen megnött $(24,8 \pm 4,6 \mu \mathrm{m} / \mathrm{min}, n=55)$ a vadhoz képest $(17,9 \pm 3,5 \mu \mathrm{m} / \mathrm{min}, n=56)$, a MT-ok növekedésének idötartama változatlan. Átlag \pm szórás, t-próba, *** $p<0.001, n s-n e m$ szignifikáns a különbség. (C) EB1-GFP-t kifejezö vad és shot ${ }^{s 20}$ mutáns hámsejteken 10 egymást követö kép egyesitve mutatja az egyedi MT-ok útját $(11 \mathrm{sec}$ ). (D) Kördiagram a MT-ok növekedési irányáról EB 1-GFP-t kifejezö vad ( $n=181,4$ sejt, 2 embrió) és shot ${ }^{s 20}$ mutáns DME sejtekben $\quad(n=269 \quad 4$ sejt, 2 embrió). (A felvételek megtekinthetök: http://movie.biologists.com/video/10.1242/jcs.193003/video-4) 
A mutáns hámsejtekben a MT-ok növekedési sebessége jelentősen megnőtt $(24,8 \pm 4,6$ $\mu \mathrm{m} / \mathrm{min})$ a vad sejtekhez képest $(17,9 \pm 3,5 \mu \mathrm{m} / \mathrm{min})$. Ez az eredmény szintén azt támasztja alá, hogy a Shot fehérje a MT-ok dinamikáját szabályozza és azon keresztül hat a háti záródásra (22. ábra A). A MT-ok növekedésének időtartama a mutáns és a vad sejtekben nem mutatott jelentős különbséget, ami viszont arra utal, hogy a MT-ok katasztrófa frekvenciájára már nincs hatással a Shot fehérje (22. ábra B). Korábbi tanulmányok már kimutatták, hogy az ACF7 képes a MT-ok növekvő „,+”végeit az aktin kötegek mentén vezetni és ezáltal meghatározni az egyedi MT-ok növekedési irányát [67]. Az EB1-GFP markerfehérjét in vivo filmezéssel nyomon követve a MT-ok növekedési iránya is jól jellemezhetö. A vad és shot mutáns sejtek sejttestjeiben a legtöbb MT párhuzamos kötegekbe rendeződött (22. ábra C), és a MT-ok növekedési irányában sem találtunk szignifikáns különbséget (22. ábra D). Ezek az eredmények azt jelzik, hogy a Shot fehérje nem szükséges a MT-ok növekedési irányának szabályozásához az aktin kötegek mentén a háti záródás alatt. Megfigyelések összefoglalva arra utalnak, hogy a Shot fehérje a DME sejtekben lévő dinamikus MT-ok stabilizálásán keresztül hat a MT váz kialakulására a háti záródás során. 


\section{A Shot fehérje aktin-MT keresztkötő aktivitása szükséges a MT-ok stabilizálásához}

Annak érdekében, hogy jobban megértsük a Shot fehérje miként stabilizálja a MT-okat a háti záródás alatt, részletes szerkezet-funkció analízist végeztünk el. Immunfestéssel vizsgáltuk meg a MT váz elrendeződését izoforma-specifikus shot mutáns hámsejtekben, az eredményeket pedig a teljes hosszúságú, illetve csonkolt doménszerkezetü GFP jelölt fehérjékkel elvégzett menekítési kisérletekkel egészítettük ki. A menekítési kísérleteket minden esetben $s h o t^{s f 20}$ null mutáns háttéren $e n-G a l 4$ driver segítségével végeztük el. Mivel az en-Gal4 a hámban négy sejt szélessségű sávokban fejezte ki a Shot fehérje különböző változatait, ez a kísérleti elrendezés lehetővé tette, hogy a mutáns és a menekített fenotípusú sejteket ugyanabban az embrióban hasonlítsuk össze (23. ábra).
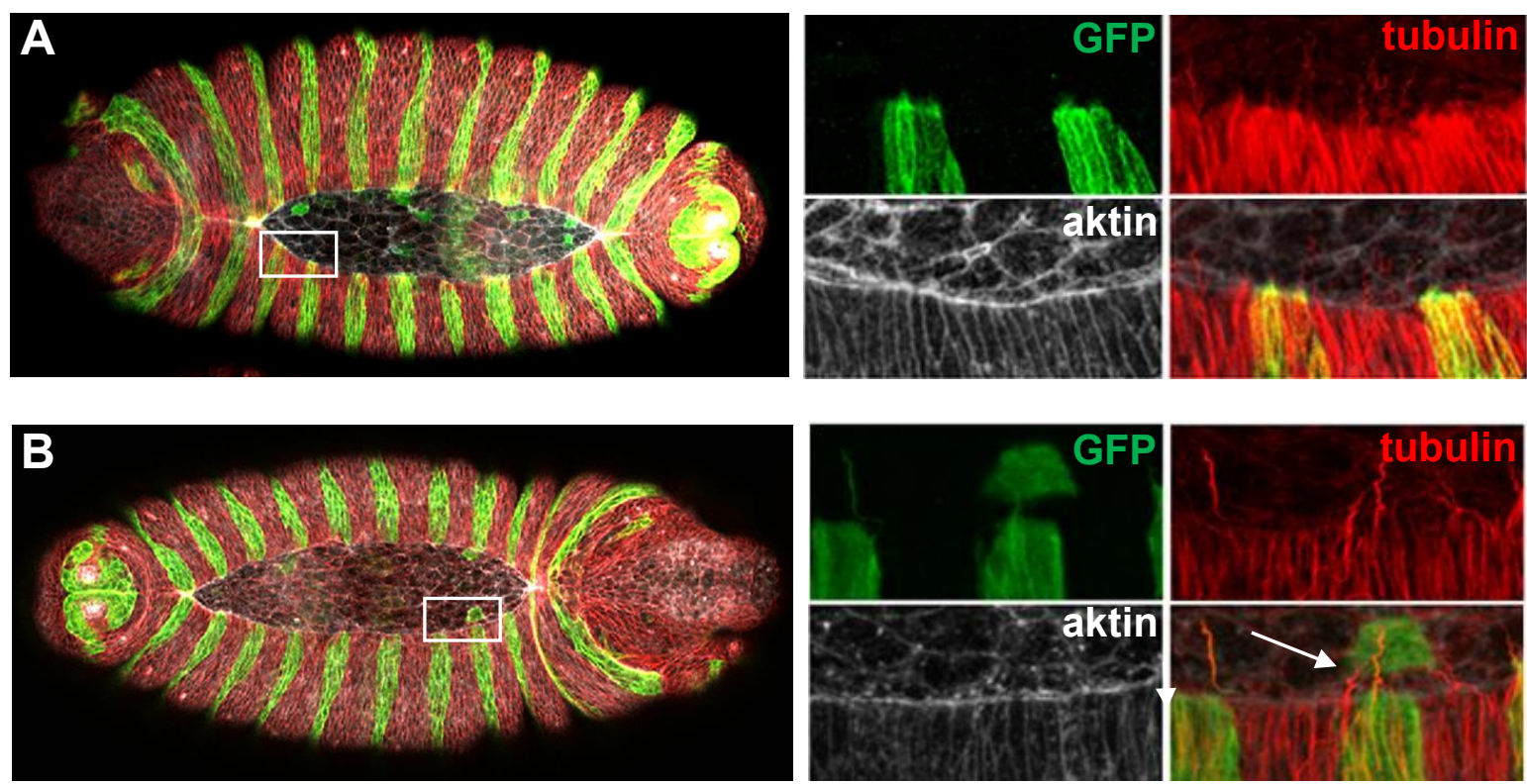

23. ábra. GFP-jelölt Shot fehérjeváltozatokat kifejező shot ${ }^{\text {f20 }}$ mutáns embriók immunhisztokémiai jelölése. (A) Menekitö, (B) nem menekitö fehérjeváltozat kifejezödése négy sejt szélességü sávokban (zöld) az en-Gal4 driver segitségével. A tubulin festés a MT-okat mutatja (piros), az aktint phalloidinnel tettük láthatóvá (szürke). Fehér nyilak a rendellenes MT-oakt mutatják. 


\section{A Shot fehérje MT-kötő aktivitása}

MT-kötő funkció hiányában, azaz a shot ${ }^{\triangle E G C}$ mutánsokban, nem meglepő módon, túlnyúló MT-fenotípust figyeltük meg (24. ábra B). A DME sejtek sejtnyúlványaiba benövő dinamikus MT-ok abnormálisak voltak. A vad típusra jellemző rövid, egyenes MT-ok helyett a shot ${ }^{\triangle E G C}$ mutáns hámsejtek sejtnyúlványaiban hosszú, meghajlott MT-ok jelentek meg. Ez a megfigyelésünk arra utal, hogy a Shot MT kötő aktivitása szükséges a normális MT váz kialakulásához a DME sejtekben. Megvizsgáltuk, hogy a MT-kötésben szerepet játszó domének közül pontosan melyik doménjén keresztül fejti ki a Shot fehérje ezt a hatását. Különböző csonkolt izoformákkal végeztünk menekítési kísérleteket és azoknak a szubcelluláris lokalizációját is részletesen jellemeztük.

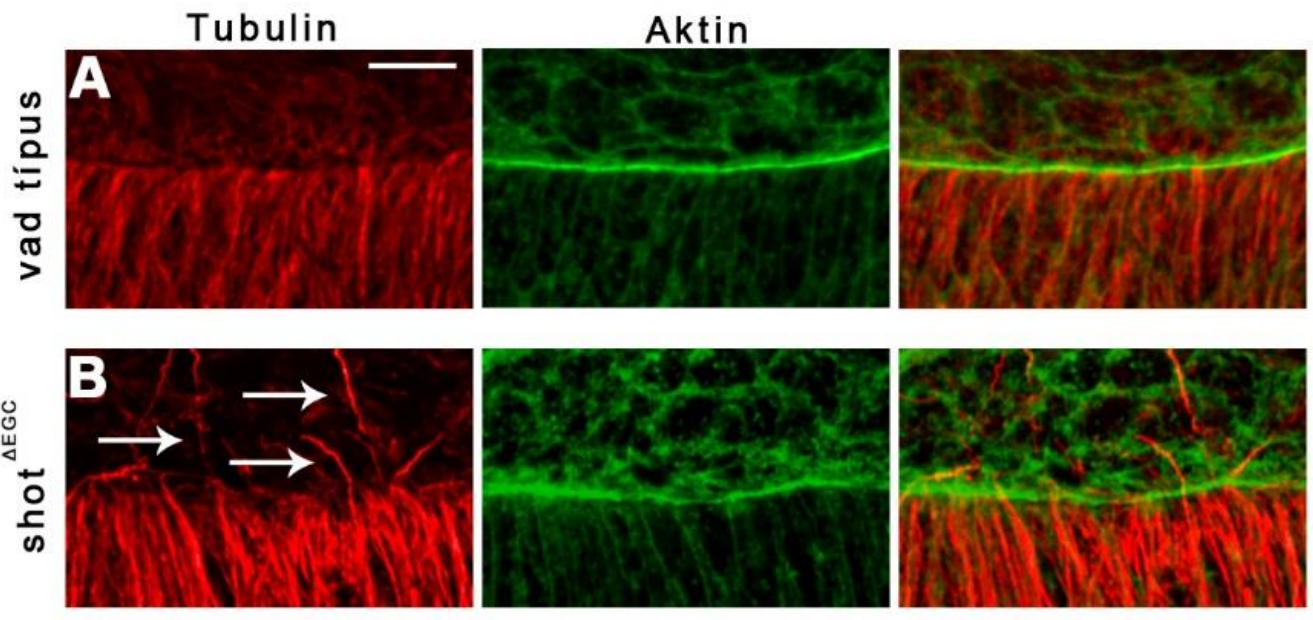

24. ábra. Rendellenes MT-ok a vezetó élben vad és shot mutáns embrióban. (A) vad (B) shot ${ }^{\Lambda E G C}$ mutáns embriók immunhisztokémiai jelölése a háti záródás alatt. A tubulin festés a MT vázat (piros), a phalloidin pedig az aktint (zöld) jelöli. A fehér nyilak a rendellenesen hosszú és meghajlott MT-okat

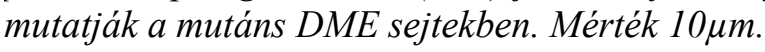

A teljes hosszúságú Shot izoforma (Shot-L(A)-GFP) főként az aktinnal mutat kolokalizációt: a sejtkéregben és a sejtnyúlványokban, valamint a vezető élben halmozódik fel. Helyenként a sejttestben a MT-okhoz is kötődik (25. ábra A). EB1-mCherry fehérjével elvégzett koexpressziós kísérletből kiderült, hogy a teljes hosszúságú Shot izoforma nem halmozódik fel a MT-ok növekvő „,” végeinél (25. ábra A’). A teljes hosszúságú fehérje túltermeltetése a vártnak megfelelően menekíti a shot mutáns MT-fenotípusát (26. ábra B, I). Az a fehérje változat, melyből hiányzik a MT „,+” vég kötésért felelős domén (Shot $\Delta \mathrm{C}$-tailGFP) diffúzan található meg a DME sejtekben. Kisebb mértékben a kortikális aktinon és a sejtnyúlványokban is előfordul (25. ábra B). A Shot $\Delta \mathrm{C}$-tail-GFP izoforma menekíti a mutáns MT fenotípust, ami arra utal, hogy a Shot fehérje kölcsönhatása az EB1 fehérjével, valamint 
felhalmozódása a MT-ok „," növekvő végeinél nem nélkülözhetetlen a MT-ok stabilizálásában (26.ábra C, I). Ezt a következtetést a Shot-L(A)-3MtLS*-GFP transzgénnel elvégzett menekítési kísérlet is alátámasztotta. Ez a transzgén három célzott mutációt hordoz, ami a ShotEB1 interakcióért felelős mindhárom SxIP motívumot érinti. A Shot-L(A)-3MtLS*_GFP menekíti a shot mutáns MT fenotípust és a teljes hosszúságú fehérjéhez hasonló lokalizációt mutat (25. ábra C, 26. ábra D, I). Ezekkel az eredményekkel összhangban, a Shot-C-tail-GFP, mely egyedül a fehérje MT „," végkötő doménjét tartalmazza a MT „,+” végekhez lokalizálódik (25. ábra D), de ez önmagában nem elég a vad típusú MT-váz helyreállításához (26. ábra E, I). Ez azt jelzi, hogy a Shot fehérje MT „,+ vég szabályozásán kívül további funkciójára is szükség van a normális MT-váz kialakulásához a háti záródás alatt.

Tovább vizsgálva a Shot fehérje MT-kötésért felelős funkcionális doménjeit, a Gas2 domén nélküli (Shot $\Delta$ Gas2-GFP) fehérjét fejeztettünk ki shot mutáns hámsejtekben. A Gas2 domén eltávolítása drámai következményeket okozott a fehérje szubcelluláris lokalizációjában, ugyanis az elvesztette a képességét, hogy a MT-ok mentén kötődjön, ehelyett a MT-ok “+” végeinél és a sejtkéregben lokalizálódik (25. ábra E). Ezt az eredményt figyelembe véve feltételezhetjük, hogy a Gas2 MT kötő domén gátolja a Shot fehérje MT-végekhez történő kötődését a C-tail doménen keresztül. A Shot $\Delta$ Gas2-GFP-vel végzett menekítési kísérletben azt tapasztaltuk, hogy a Shot $\Delta$ Gas2 fehérje menekíti a shot mutáns MT fenotípust. Ez az eredmény arra utal, hogy a Gas2 domén sem nélkülözhetetlen a MT-ok stabilizálásához (26. ábra F, I).

Az a Shot fehérjeváltozat, melyből az EF-hand domén hiányzik (Shot $\Delta$ EF-hand-GFP), hasonló lokalizációt mutat a teljes hosszúságú fehérjével (25. ábra F) és szintén menekíti az abnormális MT fenotípust (26. ábra G, I). Az EF-hand, Gas2 és C-tail doménekből álló Shot fehérje változat (EGC-GFP) a MT-ok mentén lokalizálódik (25. ábra G), de a mutáns MT fenotípust nem képes menekíteni (26. ábra H, I).

Mindezeket a menekítési kísérleteket figyelembe véve úgy tünik, hogy egyik Cterminális domén sem elég önmagában a MT-ok stabilizálásához, ami látszólag ellentmond a $s h o t^{\triangle E G C}$ mutáns embriókban leírt megfigyeléseknek. Elképzelhető viszont, hogy a DME sejtek vezető élében a Gas2 és C-tail domének redundáns funkcióval bírnak és képesek kölcsönösen helyettesíteni egymást. Összességében arra a következtetésre jutottunk, hogy a Shot fehérje MT kötő aktivitása szükséges, de nem elégséges a MT-ok stabilizálásához. 

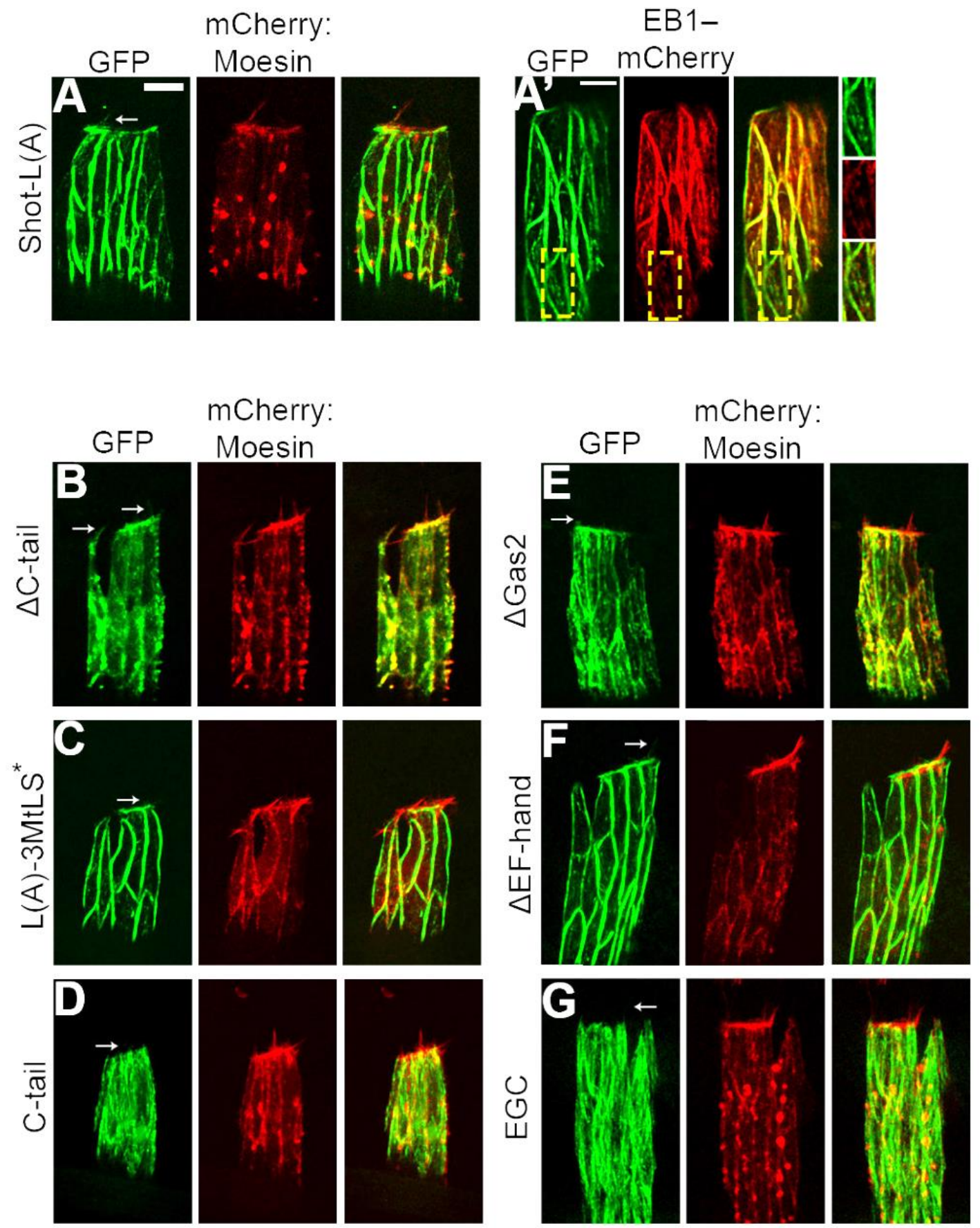

25. ábra. Különbözö Shot izoformák szubcellulális lokalizációja a DME sejtekben I. Élö embriókról készitett felvételek. A hámsejtek négy sejt széles sávban fejezik ki a GFP jelölt Shot fehérjét és mCherry:Moesint. A nyilak a Shot fehérje lokalizációját jelölik a sejtnyúlványokban. (A) Shot-L(A)-GFP-t, (A') Shot-L(A)-GFP-t és EB1-mCherry-t koexpresszáló hámsejtek., (B) Shot- $\triangle C$ tail-GFP-t, (C) Shot-L(A)-3MtLS*-GFP-t, (D) Shot-C-tail-GFP-t, (E) Shot-UGas2-GFP-t, (F) Shot$\triangle E F$-hand-GFP-t, $(G)$ Shot-EGC-GFP-t és mCherry-Moesint koexpresszáló hámsejtek. Mérték 5 um. (A felvételek megtekinthetök: http://movie.biologists.com/video/10.1242/jcs.193003/video-5, -6, $-7,-8,-9,-10,-11,-12$. 

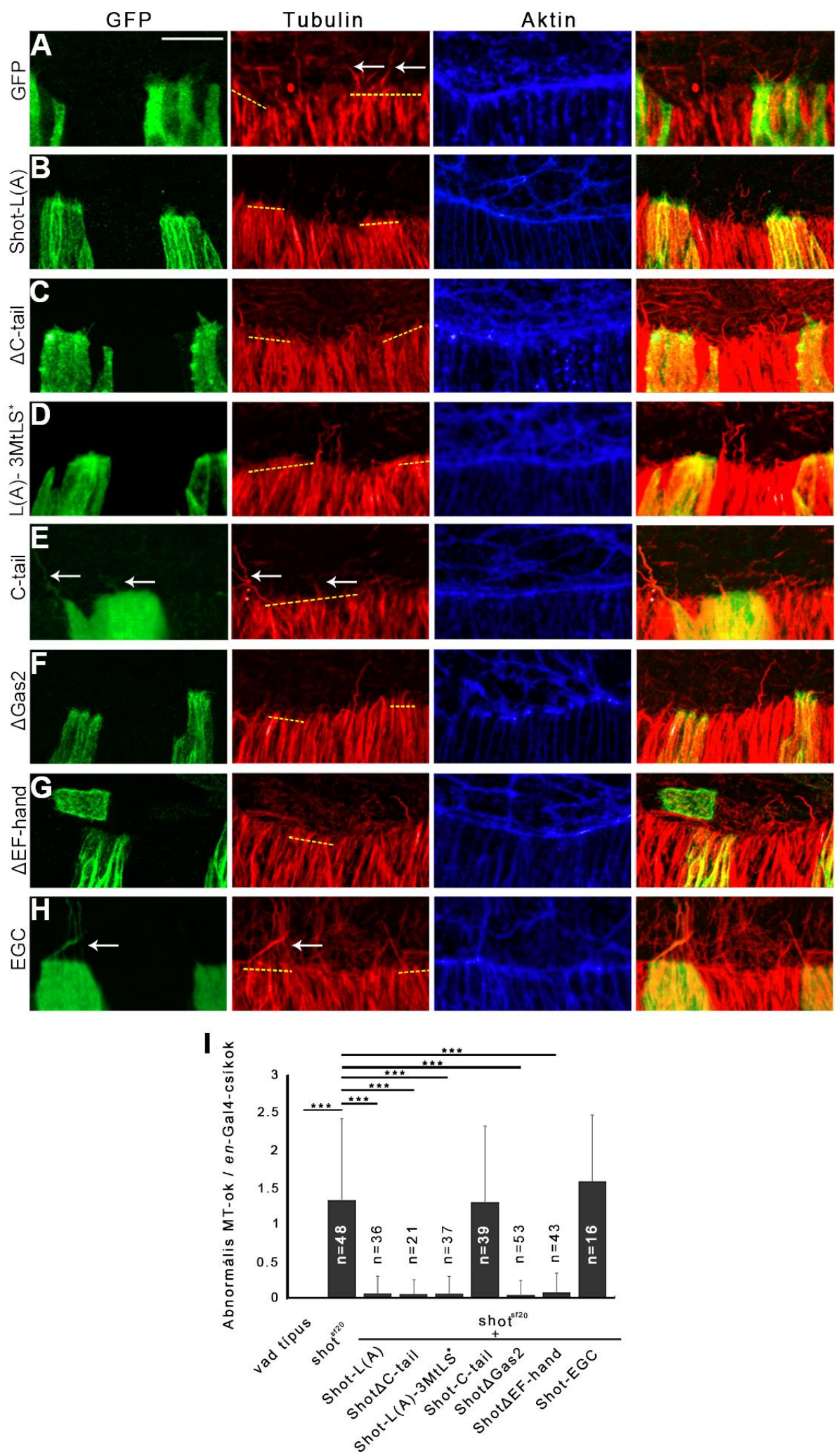

26. ábra. MT fenotípus menekitése. (A-H) En-Gal4 négy sejt szélessségü sávokban GFP-jelölt Shot fehérjeváltozatokat kifejező shot ${ }^{s 20}$ mutáns embriók immunhisztokémiai jelölése. A tubulin festés a MT hálózatot jelöli (piros), az aktint phalloidin jelöli (kék), a GFP a Shot fehérjeváltozatokat jelöli (zöld). A sárga szaggatott vonal a tubulin festésen jelzi az en-Gal4 négy sejt szélessségü sávjait. Mérték $5 \mu \mathrm{m}$. A menekitést a Shot fehérjéket kifejezö hámsejtekböl kiemelkedö, hosszú meghajlott MT-ok hiánya jelzi (fehér nyilak). (I) Az en-Gal4 sávokban megfigyelt abnormális MT-ok száma a DME sejtek élvonalában. Átlag \pm szórás, t-próba, *** $p<0.001$. 


\section{A Shot fehérje aktinkötö aktivitása}

A következő lépésben a Shot aktinkötő képességét teszteltük, hogy meghatározzuk, részt vesz-e a MT-ok stabilizálásában. Az aktin kötésre képtelen shot ${ }^{k a k P 1}$ mutáns DME sejtekben a $s h o t^{s f 20}$ és $s h o t^{\triangle E G C}$ mutánsokhoz hasonlóan abnormálisan hosszú és meggörbült MT-okat találtunk a DME sejtekben, ami arra utal, hogy a Shot aktinkötő képessége csakugyan szükséges a MT-ok stabilizálásához (27. ábra B). Ezt az eredményt a Shot $\Delta$ CH1-GFP transzgénnel elvégzett menekítési kísérlettel támasztottuk alá. Ebből a fehérje változatból hiányzik a CH1 aktinkötő domén, ezáltal az aktinkötő képességét is elvesztette. Ezért ez a fehérjeváltozat nem köt a sejtkéreghez, ellenben nagyon erős lokalizációt mutat a MT-ok mentén a sejttestben (28. ábra B). Ez a CH1 domén gátló hatásával magyarázható, amit a Shot fehérje MT-kötő képességére gyakorol. Ezek a MT-ok rendellenesen összecsavarodtak és meghajlottak voltak. Érdekes módon viszont a Shot $\Delta \mathrm{CH} 1-$ GFP képes volt menekíteni a mutáns túlnyúló MT fenotípust (29. ábra C, E), ami látszólag ellentmond a korábbi megfigyeléseinknek, miszerint a shot ${ }^{k a k P 1}$ mutánsban abnormális MT-okat írtunk le. Ez az eredmény felveti a Shot $\triangle \mathrm{CH} 1-\mathrm{GFP}$ fehérjeváltozat túltermelésének domináns negatív hatását. A Shot fehérjének ezt a hatását már korábban is leírtak, pl. a Shot fehérje túltermeltetése neuronokban vagy C-terminális csonkolása a MT hálózat szerveződésének hibáit eredményezi [98, 99]. Feltételezésünk szerint a Shot $\Delta \mathrm{CH} 1-\mathrm{GFP}$ túltermelése a DME sejtekben megakadályozza a MT-ok túlnyúlását, de nem állítja helyre a vad MT eloszlást.

Összefoglalva, a shot ${ }^{k a k P 1}$ mutáns fenotípusa alapján arra a következtetésre jutottunk, hogy a Shot aktinkötő képessége, csakúgy, mint a MT-kötő képessége szükséges a MT-ok stabilizálásához. További bizonyítékot ad erre a Shot $\Delta \mathrm{CH} 1 \Delta \mathrm{Gas} 2-\mathrm{GFP}$ fehérje változat túltermeltetése, amelyből mindkét funkcionális domén (MT-kötő ás aktin-kötő) egyidejüleg hiányzik. A Shot $\Delta \mathrm{CH} 1 \Delta \mathrm{Gas} 2-$ GFP fehérje a MT-ok mentén lokalizálódik (28. ábra C), ennek ellenére nem volt képes menekíteni a shot gén hiányát és az abnormális MT-ok megjelentek a DME sejtekben (29. ábra D, E).

Az is kiderült, hogy a Shot fehérje MT-kötő és az aktinkötő aktivitására egy fehérje molekulán belül van szükség a normális MT váz kialakításához, ugyanis a $s h o t^{\triangle E C G} / s h o t^{k a k P 1}$ heteroallélikus kombinációt hordozó embriókban is rendellenes MT-okat találtunk (27. ábra C). Ezekben az embriókban sohasem képződik olyan fehérje, amelynek egyidejüleg lenne aktinkötő és MT-kötő aktivitása. Eredményeink arra utalnak, hogy a Shot fehérje az aktin/MT keresztkötésével biztosítja a helyes MT-váz müködést a háti záródás cipzározódási fázisában. 

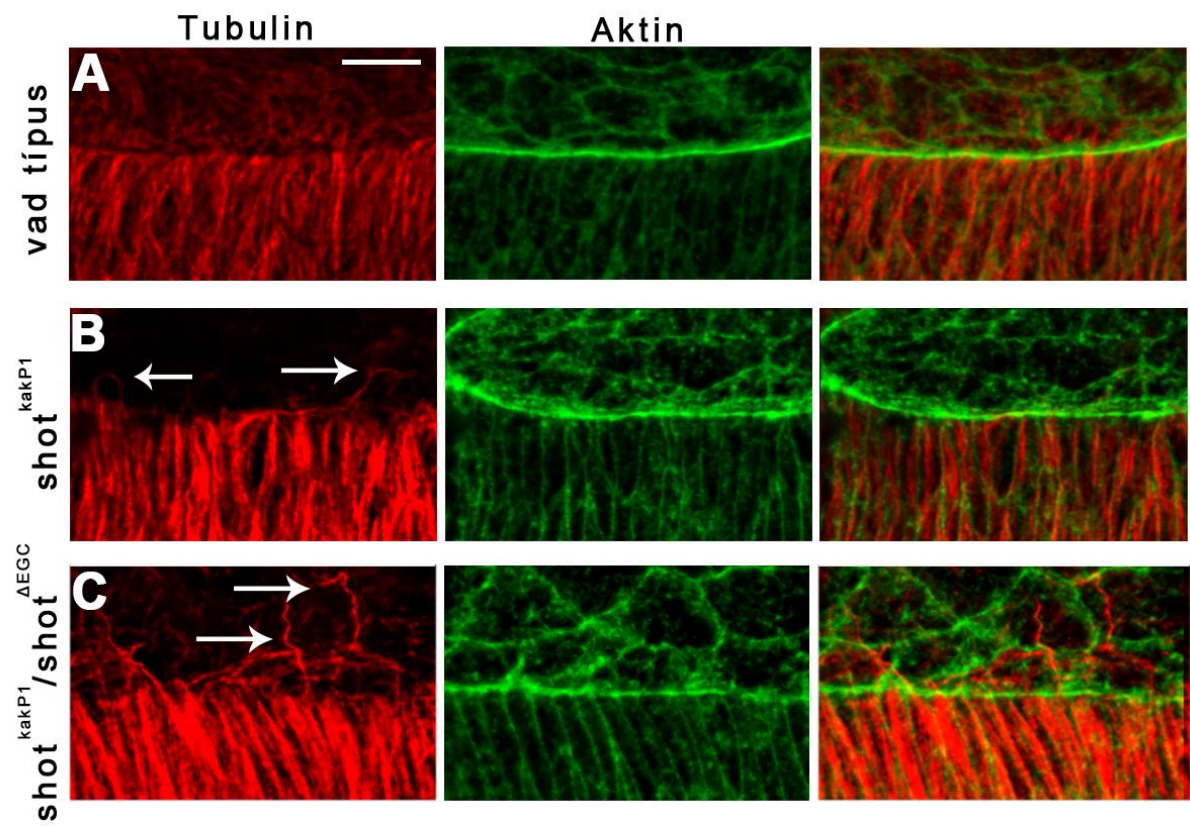

27. ábra. Rendellenes MT-ok a vezetö élben vad és különbözö shot mutáns embriókban. (A) vad (B) shot $^{k a k P 1}$ és (C) shot ${ }^{k a k P 1} /$ shot ${ }^{4 E G C}$ mutáns embriók immunhisztokémiai jelölése a háti záródás alatt. A tubulin festés a MT vázat (piros), a phalloidin pedig az aktint (zöld) jelöli. A fehér nyilak a rendellenesen

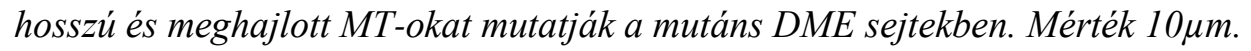

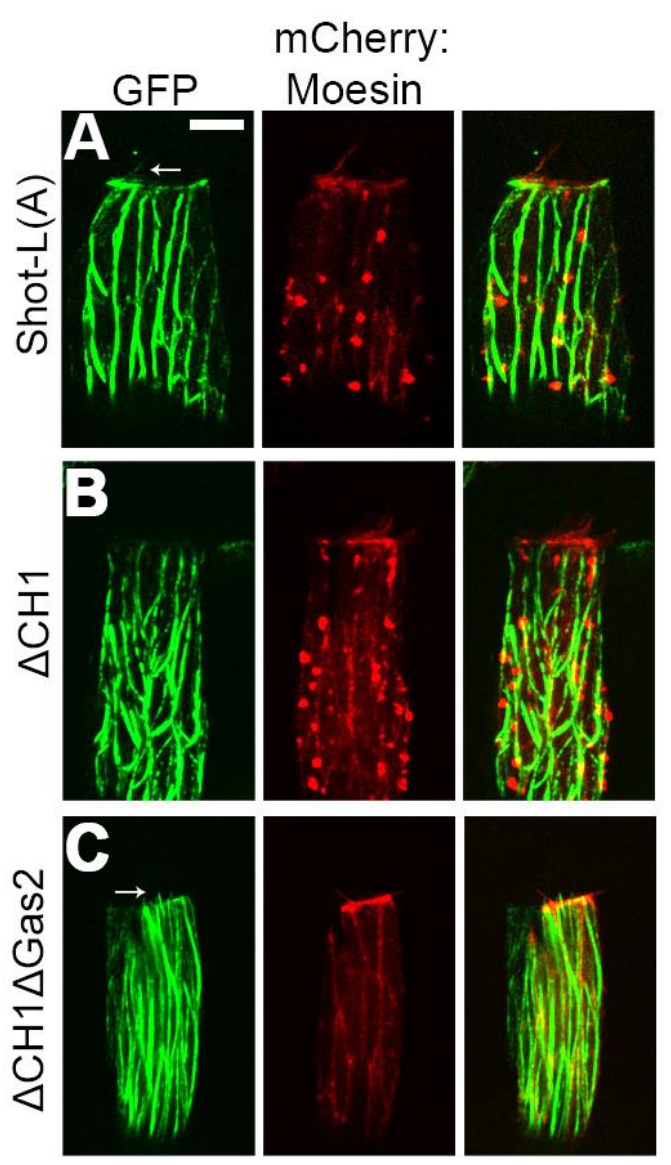

28. ábra. Különbözö Shot izoformák szubcellulális lokalizációja a DME sejtekben II. (A) Shot-L(A)-GFP-t, (B) Shot $\triangle C H 1-G F P-t$, (C) Shot- $\triangle C H 1 \Delta G a s 2$ GFP-t és mCherry:Moesint koexpresszáló DME sejtek. A nyilak a Shot fehérje változatok lokalizációját jelölik a sejtnyúlványokban. Mérték $5 \mu \mathrm{m}$ (A felvételek megtekinthetök: http://movie.biologists.com/video/10.1242/jcs. 193003/video-5, - 13, -14). 

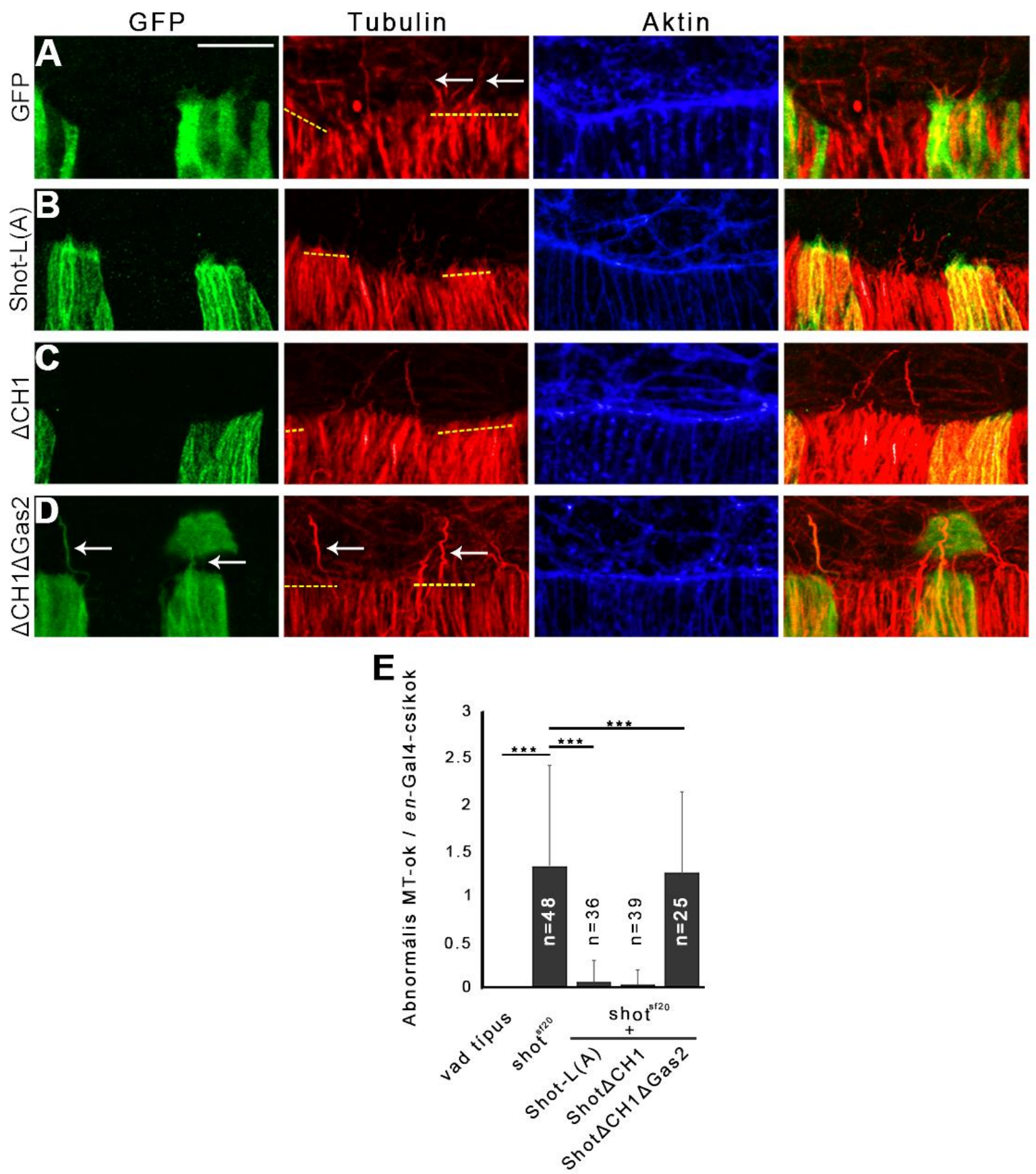

29. ábra. A Shot fehérje MT-kötő és az aktinkötő aktivitása egyidejüleg szükséges a normális MT váz kialakitásához a DME sejtekben. (A-D) En-Gal4 négy sejt szélessségü sávokban GFP-jelölt Shot fehérjeváltozatokat kifejezö shot ${ }^{\mathrm{s} 20}$ mutáns embriók immunhisztokémiai jelölése. A tubulin festés a MT hálózatot jelöli (piros), az aktint phalloidin jelöli (kék), a GFP a Shot fehérjeváltozatokat jelöli (zöld). A sárga szaggatott vonal a tubulin festésen jelzi az en-Gal4 négy sejt szélessségü sávjait. Mérték $5 \mu \mathrm{m}$. A menekitést a Shot fehérjéket kifejezö hámsejtekböl kiemelkedö, hosszú meghajlott MT-ok hiánya jelzi (fehér nyilak). (E) Az en-Gal4 sávokban megfigyelt abnormális MT-ok száma a DME sejtek élvonalában. Attlag \pm szórás, t-próba, $* * * p<0.001$. 


\section{A Shot fehérje elősegíti a filopódium képződést a vezető élben}

Az eddigi eredmények alapján elmondható, hogy a Shot fehérje aktin és MT szabályozó funkciójára egyidejüleg van szükség a DME sejtekben a helyes MT váz kialakulásához és így a normális háti záródáshoz. A menekítési kísérletekből viszont kiderült, hogy a MT-váz helyreállítása nem elegendő a normális dinamikájú háti záródáshoz, tehát a Shot fehérje további funkcióira is szükség van. Ilyen funkció lehet a Shot fehérje aktinváz müködésében játszott szerepe. Megvizsgáltuk az aktin felhalmozódást és a filopódiumok kialakulását a vezető élben. En-Gal4 driver segítségével aktin-EGFP-t fejeztettünk ki vad és különböző shot mutáns hámokban, így in vivo videomikroszkópiával könnyen nyomon tudtuk követni az összes aktin alapú struktúrát (30. ábra A). A vad és a különböző shot mutáns hámokban az aktin felhalmozódás a DME sejtek vezető éljében nem sérült és a dinamikus aktin alapú sejtnyúlványok, a filopódiumok is megjelentek (30. ábra B). Közelebbről megvizsgálva a vezető élt viszont azt találtuk, hogy a shot ${ }^{520}$ mutánsban, annak ellenére, hogy a filopódiumok a vad típushoz hasonlítottak, néha rendkívül hosszú $(10 \mu \mathrm{m})$ nyúlványok alakultak ki, melyek nagyon halványan jelölődtek aktin-EGFP-vel. Elképzelhető, hogy ezekbe a nyúlványokba nőnek bele az abnormális MT-ok. A shot ${ }^{s f 20}$ null mutáns embriók DME sejtjeiben a filopódiumok száma jelentősen lecsökkent a vad típushoz képest, ami arra utal, hogy a Shot fehérje részt vesz a filopódiumok kialakulásában (30. ábra C). A filopódiumok számának csökkenése a Shot fehérje aktin-MT keresztkötési aktivitás elvesztésének eredménye, ugyanis shot $^{k a k P 1}$ és a shot ${ }^{\triangle E G C}$ mutáns embriókban is jelentős filopódiumszám-csökkenést tudtunk megfigyelni (30. ábra C). A Shot fehérje keresztkötő aktivitásának szükségességét bizonyítja az a megfigyelésünk is, hogy a MT- és aktinkötő doméneknek egy molekulán belül kell lenniük, amit a filopódiumok csökkent száma jelez a shot ${ }^{\Delta E C G} / s h o t^{k a k P 1}$ transzheterozigóta embriókban (30. ábra C). Megfigyeléseink arra utalnak, hogy a Shot fehérje részt vesz a filopódiumok kialakulásának szabályozásában és ezen keresztül hat a háti záródásra. 
A
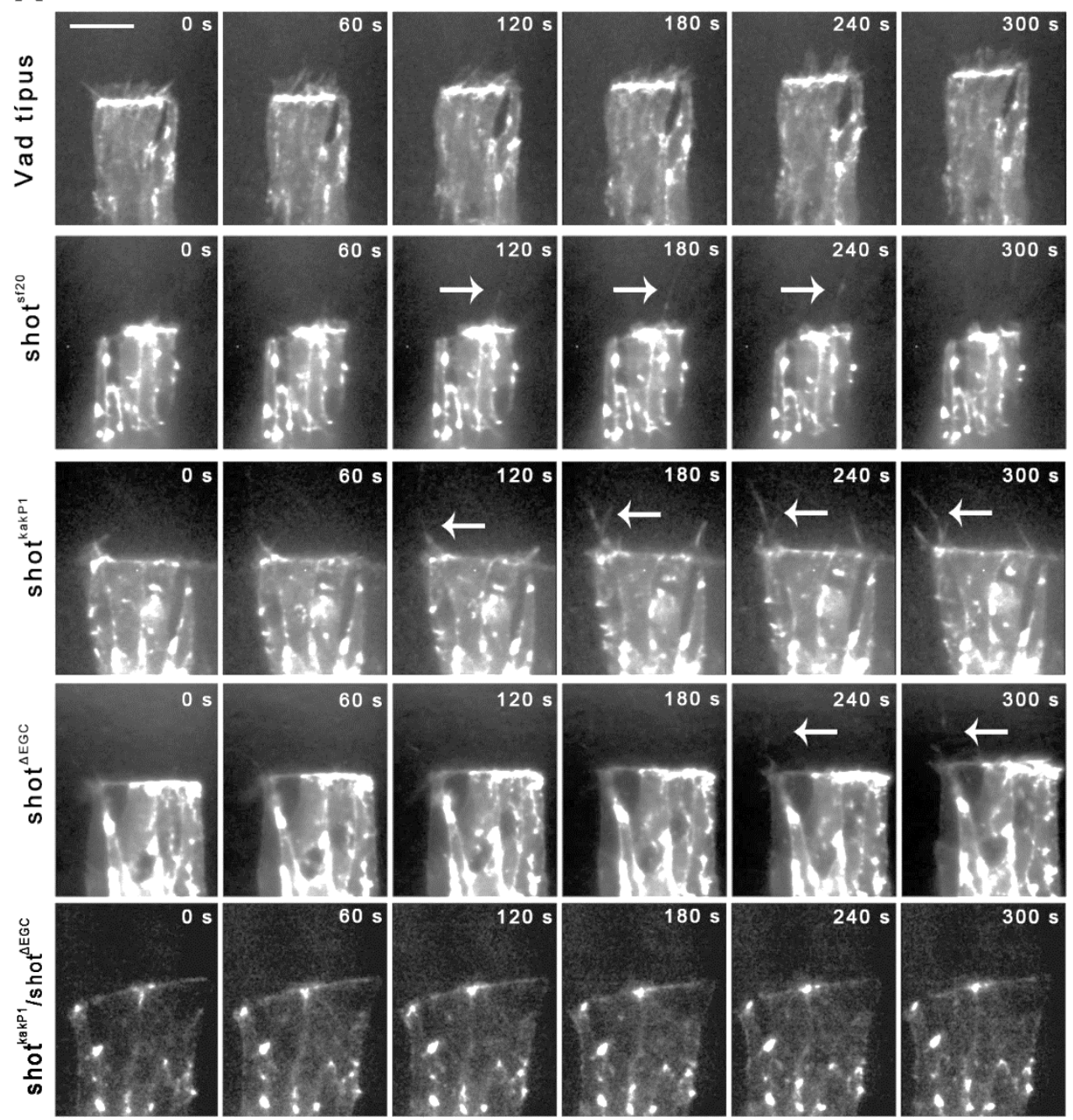

B

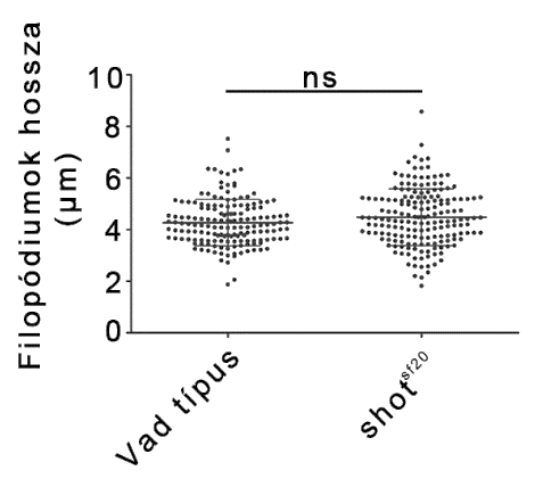

C

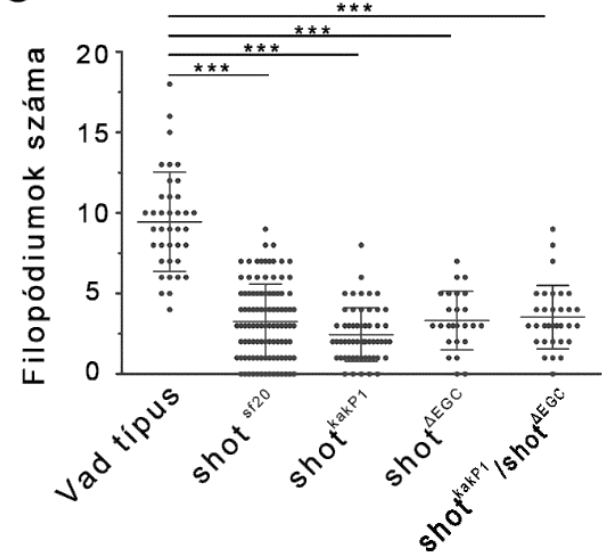

30. ábra. (A) Aktin-EGFP-t kifejező hámsejtek sejtnyúlványainak dinamikája vad és shot mutáns embriókban. A fehér nyilak a hosszú sejtnyúlványokat jelülik. Mérték $10 \mu \mathrm{m}$. (B, C) A filopódiumok dinamikájának kvantitativ elemzése. (B) A diagram a filopódiumok hosszát, (C) és a 15 perc alatt kialakuló filopódiumok számát mutatja a DME sejtekben. Shot mutánsban kevesebb filopódium alakul ki a vad típushoz képest, de a filopódiumok hosszában nincs jelentős különbség. Átlag \pm szórás, t-próba, *** p<0.001, ns - nem szignifikáns a különbség (A felvételek megtekinthetök: http://movie.biologists.com/video/10.1242/jcs.193003/video-15). 


\section{AZ EREDMÉNYEK MEGVITATÁSA}

Kísérleteink célja a hámzáródási folyamatok során lejátszódó sejtvázátrendeződések alapmechanizmusainak megismerése volt a háti záródás vizsgálatán keresztül. A háti záródásban szerepet játszó új gének azonosításához egy funkcióvesztéses genetikai szürést végeztünk RNSi felhasználásával. A funkcióvesztéses fenotípust in vivo videó-mikroszkópiával nyomon követve olyan géneket is lehet azonosítani, melyek a háti záródás dinamikáját szabályozzák. A MT-okkal együttmüködő fehérjéket kódoló gének típikusan ilyenek lehetnek, hiszen a MT-ok teljes hiánya is csupán a cipzározódási hibákat eredményez, ami csak élő embrió filmezésével vizsgálható. 17 MT-vázhoz kapcsolódó fehérjét kódoló gént csendesítve azonosítottuk a spektraplakint kódoló shot gént, melynek hiánya abnormális dinamikájú háti záródást okozott. Bebizonyítottuk, hogy a fenotípus valóban a shot gén hiányából adódik. Az embrionális háti záródás folyamatán kívül a Drosophila Shot fehérje egyéb fejlődési folyamatok szabályozásában is részt vesz (torzáródás, sebzáródás), ami a hámzáródási folyamatokban betöltött általános szerepére utal.

A Shot fehérje a sejtváz egyik kulcsfontosságú szerkezeti eleme. A sejtalak megváltozásához szükséges sejtváz-átrendeződéseket irányító folyamatokban vesz részt. Mivel a génről nagyszámú, különböző doménekkel rendelkező fehérje képződhet, a shot gén szerepének magyarázatára a háti záródásban számos, egymást ki nem záró lehetőség kínálkozik. Minket elsősorban az érdekelt, hogy a shot gén milyen módon járul hozzá a mikrotubulusváz szerkezeti átalakulásához és a mikrotubulusváz által kiváltott, a hámzáródáshoz szükséges sejtszintű változásokhoz. Kísérleteink során két különböző fenotípusos elváltozást követtünk nyomon: a háti nyílás záródásának dinamikáját és a sejtvázelemek szerkezeti és működési hibáit.

\section{A Shot fehérje a MT-váz helyes kialakulását szabályozza a háti záródás alatt}

A hámban megfigyelhető MT-okat eltérő eloszlásuk és stabilitásuk alapján három különböző csoportba sorolhatjuk. Az első csoportba azok a MT-ok tartoznak, melyek az $\alpha$ tubulin speciális poszttranszlációs módosítását, acetilációját hordozzák, melyek elsősorban a hosszú életidejű, stabil MT-on találhatók meg [100-105]. Ezek a MT-ok a FRAP kísérletben kimutatott immobilis tubulin frakciót képviselik a DME sejtekben. Az alacsony immobilis frakció alapján a stabilizált MT-ok igen kis hányadát alkotják a MT-oknak (20\%). Az acetilált MT-ok túlnyomórészt a sejtek apikális felszínén figyelhetők meg ahol párhuzamos kötegekbe 
rendeződnek. Ez a MT elrendeződés specifikus a háti záródásra és úgy tűnik, hogy független a spektraplakin aktivitástól, amit alátámaszt a shot mutánsban megfigyelhető normális acetilált MT eloszlás is.

A második csoportot a sejttestben megtalálható dinamikus MT-ok alkotják, melyek ellentétes lefutású stabil kötegekbe rendeződnek és a DME sejtek dorzális vagy ventrális felszíne felé nőnek. A Shot fehérje szerepe lehet a MT-ok növekedésének irányítása a már kialakult aktin filamentumok mentén. In vitro kísérleti eredmények alapján a Shot fehérje képes az aktin kötegek mentén irányítani a MT-ok növekedését, ami a MT-ok párhuzamos kötegekbe történő összerendeződését eredményezi [106]. Ehhez az aktivitáshoz a Shot fehérje a MT-ok “+” végével lép kölcsönhatásba a C-tail doménen keresztül [88, 106]. Eredményeink szerint a C-tail domén müködése nem szükséges a helyes MT váz kialakulásához a háti záródás alatt. EB1-GFP markerfehérjével az egyedi MT-okat nyomon követve kimutattuk, hogy a Shot nem játszik szerepet a MT-ok növekedés irányának meghatározásában a háti záródás alatt. Mindezek alapján azt feltételezzük, hogy a dinamikus MT-ok párhuzamos kötegekbe rendeződéséért nem a Shot által közvetített MT- aktin kölcsönhatáson alapuló MT-vezetés a felelős. A DME sejtek MT-ainak elrendezésében valószínűleg eddig ismeretlen, motorfehérjék által hajtott irányító mechanizmusok vehetnek részt [107-110]. A Shot fehérje gátolja a MT-ok polimerizációját, amit a mutáns DME sejtekben megfigyelt magasabb MT növekedési sebesség és a FRAP kísérlettel kimutatott gyorsabb tubulin kicserélődés jelez. A Shot fehérje hasonló szerepét a MT növekedés sebességének szabályozásában már korábban is leírták Drosophila neuron és humán U2OS sejtkultúrákban is $[88,111]$. A gyorsan növekvő MT-ok miután elérték a sejtkérget tovább nőnek és túlnyúlnak azon vagy visszahajlanak, ami a rendezetlen MT váz kialakulását eredményezi a mutáns sejtekben. Íly módon, a MT-ok + vég dinamikájának Shot függő szabályozása hozzájárul a teljes MT hálózat szerveződéséhez a sejttestben.

A DME sejtek MT-ainak harmadik csoportjába azok a dinamikus MT-ok tartoznak, amelyek elérik a vezető élt a növekvő “+” végeikkel és belenőnek a sejtnyúlványokba. Ezeket a MT-okat erősen befolyásolják a shot mutációk: a MT-ok abnormálisan hosszúak és hajlottak lesznek. Hasonló MT-okat figyeltek meg shot vagy ACF7 hiányában számos más sejttípusnál is, mint például az emlős keratinociták, endotél sejtek, Drosophila S2 sejtek vagy neuronok esetén [67, 112-114].

A Shot fehérjének a MT-okkal és aktin filamentumokkal egyidejüleg kell kölcsönhatásba lépnie ahhoz, hogy befolyásolni tudja a MT-ok müködését. Ez a megfigyelés összhangban van azzal a hipotézissel, miszerint az abnormális MT-ok akkor alakulnak ki a sejtek perifériáján, ha nem kapcsolódnak hozzá a kortikális aktin hálózathoz [112, 115, 116]. 
Eredményeinkkel sikerült bizonyítani, hogy a Shot az N-terminális aktinkötő doménje és a C-terminális MT-kötő doménjei segítségével a sejtnyúlványokban az aktinfilamentumok és a MT-ok keresztkötését végzi és a dinamikus MT-ok stabilizálásán keresztül hat a MT váz kialakulására a háti záródás során.

\section{A Shot fehérje a filopódiumok kialakulásán keresztül segíti elő a cipzározódást}

A spektraplakin fehérjék a sejtváz különböző összetevőinek összehangolt müködését szabályozzák. A különböző izoformák doménszerkezetüktől függően a MT-okat és az aktin filamentumokat egymástól függetlenül irányítják, vagy ezek között keresztkötéseket kialakítva látják el funkciójukat. Mivel a háti záródásban mindkét sejtvázelem aktívan részt vesz, ezért a Shot fehérje is több ponton szabályozhatja a folyamatot. A háti záródás kezdeti fázisában a hámlemezek mozgását a shot mutációja nem befolyásolja és a Shot fehérje nem szükséges az aktin alapú folyamatok szabályozásához, ellenben a háti záródás utolsó lépéséhez, a normális dinamikájú cipzározódáshoz nélkülözhetetlen. A cipzározódást két sejtszintű mechanizmus segíti elő. Egyrészt a filopódiumok müködése az új sejtkapcsolatok szegment specifikus kialakulását biztosítja, másrészt pedig a szemben lévő hámlemezek lamelláinak átfedése is a cipzározódást segíti [10]. Eredményeink azt sugalják, hogy a Shot a sejtnyúlványok kialakulásán keresztül és nem a lamellák átlapolódásának feloldásán keresztül hat a cipzározódásra. A lamellák átlapolódása és feloldása egy MT-függő folyamat [10]. Habár nem tudjuk kizárni a Shot MT-szabályozó funkciójának közvetlen szerepét ebben a folyamatban, menekítési kísérleteink egyértelmüen igazolják, hogy a Shot MT-szabályozó funkciója mellett aktin-kötő aktivitása is szükséges a cipzározódáshoz. Nyilvánvalóan a MT-ok stabilizálása önmagában nem elegendő a normális dinamikájú háti záródáshoz.

A DME sejtekben a sejtnyúlványok helyes müködéséhez a Shot fehérje aktin és MTkötő aktivitásának összehangolt müködése szükséges. Az is biztos, hogy a Shot aktin és MT kötő doménjének egy molekulán belül kell lenniük, ami arra utal, hogy a Shot fehérje MT/aktin keresztkötő funkciója érvényesül ebben a folyamatban.

A DME sejtekben a MT-ok és aktin filamentumok kolokalizációját kizárólag a filopódiumokban tudtuk kimutatni, vagyis a Shot fehérje a keresztkötő aktivitását a sejtnyúlványokban fejti ki. Ezt a következtetést támasztja alá a filopódiumok csökkent száma a shot mutánsban. Feltételezzük, hogy a shot mutánsban a Shot aktin/MT keresztkötő aktivitásának hiánya okozza a sejtnyúlványok csökkent számát, ami végsősoron ahhoz vezet, hogy a cipzározódás lelassul. 
A Shot fehérjék moduláris doménszerkezetüknek köszönhetően sejttípus-függủ módon szabályozzák a sejtnyúlványok dinamikáját. Az idegsejtek növekedési kúpjában a Shot fehérje az EF-hand $\mathrm{Ca}^{2+}$ kötő doménjén keresztül kölcsönhatásba lép a Kra (más néven eIF5C) fehérjével és ez esszenciális a filopódiumok kialakulásához [113]. A DME sejtekben azonban az EF-hand domén nem szükséges a háti záródáshoz, ellenben az aktinkötő és a MT kötő funkció esszenciális a filopódiumok helyes működéséhez és ezen keresztül a cipzározódáshoz. Emlős sejtkultúrákban az ACF7 kölcsönhatása az ELMO komplexel (más néven DOCK180) segíti elő a filopódiumok kialakulását a MT-ok stabilizálásán és a Rac GTP-ázok aktivitásán keresztül [117]. Lehetséges, hogy egy hasonló mechanizmus müködik a DME sejtekben is. A Shot fehérje kölcsönhatása az ELMO komplexel (Drosophilában Mbc) stabilizálja a MT-okat azáltal, hogy keresztköti azokat az aktin filamentumokkal és Rac-aktivációt indukál a vezető élben. Ezt a feltételezést támasztja alá az is, hogy a Rac aktiváció szükséges a sejtnyúlványok kialakulásához és a hatékony cipzározódáshoz [44, 118].

A shot teljes hiánya nem akadályozza meg a háti záródást, csupán egy enyhe fenotípust, cipzározódási hibát okoz a háti záródás alatt. A shot null mutánsokra jellemző enyhe záródási fenotípus két, egymást nem kizáró hipotézissel magyarázható. Előfordulhat, hogy további keresztkötő fehérjék vagy keresztkötő mechanizmusok hathatnak párhuzamosan a Shot fehérjével. Egy ilyen potenciális redundáns szereppel bíró keresztkötő fehérje lehet a Pigs, amelyröl kimutatták hogy $\mathrm{CH} 1$, Gas2 és C-tail doméneket is tartalmaz, melyekkel valamennyi sejtvázelemhez kötődni tud [119]. A másik magyarázat szerint elképzelhető, hogy a Shot szerepe a DME sejtekben csupán a sejtnyúlványok kialakulására korlátozódik. A sejtnyúlványok számának csökkenése a shot mutánsban így nem teszi lehetetlenné a cipzározódást, de jelentősen lecsökkenti a hatékonyságát [7, 10]. 


\section{TARTALMI ÖSSZEFOGLALÓ}

Az ember embrionális fejlődése során számos olyan lépés történik, például a szájpadlás vagy az állkapocs kialakulása során, amikor a test két oldalán létrejött szövetek a középvonal felé mozognak, és ott összeolvadva kialakítják a megfelelő szerveket. Ezekben a szigorúan szabályozott folyamatokban bekövetkezett hibák olyan fejlődési rendellenességekhez vezethetnek, mint a nyitott gerinc vagy a farkastorok. Az embrionális fejlődés során történő szövetösszenövésekhez hasonló folyamatok mennek végbe a természetes módon vagy sebzés hatására létrejött hámhiányosságok bezárásakor is. A hámzáródási folyamatok alapvető mechanizmusainak mélyebb megértése, a benne részt vevő molekulák felderítése és vizsgálata éppen ezért, hosszú távon felgyorsíthatják a sebgyógyulást elősegítő újszerű eljárások kifejlesztését. Kutatásainkkal azokat a stratégiákat szeretnénk megismerni és megérteni, amiket az élőlények alkalmaznak a hámnyílások bezárásához. Az ecetmuslica (Drosophila melanogaster) fejlődő embriója kitűnően alkalmas modellt kínál a középvonali összenövések és a sebzáródási folyamatok során lezajló molekuláris, illetve sejt- és szövetszintü változások in vivo vizsgálatához. Az ecetmuslica közismerten hatékony kísérleti rendszer a különböző fejlődési folyamatok genetikai boncolásához. Több évtizedes kutatás eredményeként a genetikai eszközök olyan tárháza áll rendelkezésre, mely a muslicát egyedülállóvá teszi a modellorganizmusok között. A muslica egyedfejlődése során számos olyan folyamat zajlik le, mint például az embrió háti záródása, amelyek során a sejtek a mesterségesen okozott seb záródásakor tapasztalt módon viselkednek. A háti záródás az embriogenezis utolsó morfogenetikai mozgása, melynek során két egyrétegủ hámlemez mozog egymás felé, majd találkoznak és összeolvadnak, ezáltal bezárva egy nyílást a háti középvonal mentén. A sebzáródásban és a háti záródásban egyaránt fontos szerepet kap a sejtváz- az aktin és a mikrotubulus (MT) hálózat dinamikus átrendeződése. A háti záródás során a hám legdorzálisabb sejtjei (DME) egy sorba rendeződnek és kialakul egy vezető él. A DME sejtek aktint és miozint halmoznak fel, ezáltal kialakul egy szupracelluláris aktomiozin gyürü, ami a háti lyukat körülveszi. Később a DME sejtek dorzális felszínén aktinalapú sejtnyúlványokfilopódiumok és lamellipódiumok- jelennek meg. Ezek a sejtnyúlványok az új sejtkapcsolatok szegment specifikus kialakulását biztosítják a szemben lévő hámsejtek között.

A háti záródást végrehajtó sejtvázelemek közül eddig főként az aktinvázat vizsgálták, a mikrotubulusváz szerepéről azonban nagyon keveset tudunk. Ismert, hogy a záródást megelőzően a hámsejtekben a mikrotubulusok rendezetlenül, helyezkednek el. A háti záródás 
elején ez a rendezetlen mikrotubulusváz felbomlik és a MT-ok a sejt hossztengelyével párhuzamosan stabil kötegekbe rendeződnek el. A MT-ok átrendeződése elsőként a DME sejtekben indul meg és később a laterálisabban elhelyezkedő hámsejtekre is kiterjed. A MT kötegek stabilak, de az őket felépítő egyedi MT-ok dinamikusan lebomlanak és újra polimerizálódnak. A dinamikus mikrotubulusok a sejtek dorzális felszínén belenőnek a lamellipódiumokba és a filopódiumokba, ami arra utal, hogy a sejtnek ezeken a részein a két sejtvázelem szorosan együttmüködik. A záródás befejeztével a rendezett MT kötegek lebomlanak és a hámsejtekben ismét rendezetlen MT eloszlás alakul ki.

Elsődleges célunk a MT hálózat szerveződése és müködése szempontjából fontos, a háti záródásban résztvevő gének azonosítása és jellemzése volt. Összességében arra akartunk választ kapni, hogy a mikrotubulusok miként járulnak hozzá az összehangolt változások sorozatához, melyek ahhoz vezetnek, hogy az embriók hátán keletkezett nyílás látható jel nélkül tünik el. Végső célunk a hámzáródás során a MT-váz müködését is irányító shot gén funkcionális jellemzése volt és ezen keresztül megmutatni, hogy egy alapvető fejlődési folyamathoz hogyan járul hozzá a sejtvázelemek együttmüködése.

Előzetesen, a háti záródásban résztvevő, MT-kötő gének azonosítására irányuló, RNS interferencián (RNSi) alapuló in vivo video mikroszkópiával kombinált funkcióvesztéses szürésből azonosítottuk a Drosophila spektraplakint kódoló short stop (shot) gént. A shot gén csendesítése hibás dinamikájú záródást eredményezett. A csendesített embriókban a háti nyílás bezáródott, azonban a záródás menete abnormális volt: a háti nyílás alakja a vad típusra jellemző lencse alak helyett rendellenesen keskeny lett. A shot mutáns fenotípusának kvantitatív elemzésével kimutattuk, hogy a shot gén, a MT-okhoz hasonló módon, a háti hám cipzározódásához szükséges. A teljes hosszúságú fehérje shot ${ }^{s f 20}$ null mutáns háttéren elvégzett menekítési kísérlet bizonyította, hogy a fenotípus valóban a shot gén funkciójának hiányához köthető. Az embrionális háti záródás folyamatán kívül a Drosophila Shot fehérje egyéb fejlődési folyamatok szabályozásában is részt vesz (torzáródás, sebzáródás), ami a hámzáródási folyamatokban betöltött általános szerepére utal.

A magasabbrendủ állatokéhoz hasonlóan az ecetmuslica shot génje is számos protein domént tartalmaz, melyek alternatív splicinggal és szövet specifikus promóter használattal szabadon kombinálódhatnak egymással, így változatos hosszúságú és funkciójú fehérjék képződnek. A különböző fehérjedomének szerepének pontosabb megértéséhez, izoformaspecifikus mutáns allélok fenotípusát vizsgáltuk meg az eredményeket pedig transzgenikus menekítési kisérletekkel támasztottuk alá. A mutánsanalízis és a menekítési kísérletek 
együttesen azt jelzik, hogy a Shot fehérje az aktin- és a MT-váz keresztkötésével irányítja a háti záródás utolsó fázisát, a cipzározódást.

A shot mutáns záródási fenotípusa megegyezik a MT-ok teljes hiányakor jelentkező fenotípussal, ami arra utal, hogy a shot gén funkciója szükséges a hámsejtek MT-ainak müködéséhez. A shot mutáns hámsejtek MT-vázának elrendeződését immunfestéssel vizsgáltuk meg. A részletesebb elemzés érdekében, Tubulin-EGFP-t kifejező hámsejteket filmeztünk le, így közvetlenül nyomon tudtuk követni a MT-váz felépítését. A DME sejtek sejttestjében a MT-ok párhuzamos kötegekben helyezkedtek el, azonban a shot mutánsban a kötegek gyakran hirtelen meghajlottak. A shot mutáns DME sejtek vezető élében sejtnyúlványokba belépő rendellenes, meghajlott MT-okat figyeltünk meg. A vad típustól eltérően, a shot mutáns DME sejtek laterális felszínéről kinyúló abnormális MT-okat is megfigyeltünk. A túlnyúló MT fenotípus kvantitatív elemzése kimutatta, hogy a mutáns DME sejtek nyúlványaiban a MT-ok hoszabbra nőnek, mint a vad típusú sejtekben. A mutáns hámsejtekben megfigyelhető MT-túlnövéses fenotípus hátterében a MT-ok megváltozott dinamikája áll. A MT-ok dinamikus tulajdonságait FRAP analízissel vizsgáltuk meg, amiből kiderül, hogy a shot mutáns sejtekben a MT-ok dinamikusabbak voltak, ami arra utal, hogy a shot a DME sejtekben lévő dinamikus MT-ok stabilizálásán keresztül hat a MT váz kialakulására a háti záródás során. Tovább vizsgáltuk a Shot fehérje funkcióját a MT-ok növekedésének szabályozásában úgy, hogy fluoreszcensen megjelölt EB1-GFP markerfehérjét követtünk nyomon in vivo filmezéssel. Az EB1 fehérje a MT-ok növekvő “+” végéhez kötődik és így lehetővé vált a MT-ok növekedésének közvetlen mérése. A mutáns hámsejtekben a MTok növekedési sebessége jelentősen megnőtt a vad sejtekhez képest. A vad és shot mutáns sejtek sejttestjeiben a legtöbb MT párhuzamos kötegekbe rendeződött, ami azt jelzi, hogy a Shot fehérje nem szükséges a MT-ok növekedési irányának szabályozásához az aktin kötegek mentén a háti záródás alatt.

Annak érdekében, hogy jobban megértsük a Shot fehérje miként stabilizálja a MT-okat a háti záródás alatt, részletes szerkezet-funkció analízist végeztünk el. Immunfestéssel vizsgáltuk meg a MT váz elrendeződését izoforma-specifikus shot mutáns hámsejtekben, az eredményeket pedig a teljes hosszúságú, illetve csonkolt doménszerkezetű GFP jelölt fehérjékkel elvégzett menekítési kisérletekkel egészítettük ki. A menekítési kísérleteket minden esetben shot ${ }^{\mathrm{f} 20}$ null mutáns háttéren $e n$-Gal4 driver segítségével hajtottuk végre. Mivel az enGal4 a hámban négy sejt szélessségü sávokban fejezte ki a Shot fehérje különböző változatait, ez a kísérleti elrendezés lehetővé tette, hogy a mutáns és a menekített fenotípusú sejteket ugyanabban az embrióban hasonlítsuk össze. Összességében arra a következtetésre jutottunk, 
hogy a Shot fehérje aktin és MT szabályozó funkciójára egyidejüleg van szükség a DME sejtekben a helyes MT váz kialakulásához. Kimutattuk, hogy a Shot fehérje részt vesz a filopódiumok kialakulásának szabályozásában is és ezen keresztül hat a háti záródásra. A DME sejtek vezető élében a Shot fehérje aktin- MT keresztkötő aktivitása révén járul hozzá a filopódiumok kialakításához

A Shot fehérje a sejtvázelemek együttmüködését, keresztkötését koordinálja, melyen keresztül biztosítja a hámzáródáshoz szükséges sejtszintű változásokat. 


\section{SUMMARY}

Several naturally occurring morphogenetic events involve tissue movements similar to those required for wound healing. In these developmental processes, two tissues move towards each other until they meet and fuse. These closure events happen mostly during embryogenesis at the midline of the developing body. Defects of these closure events result in dramatic consequences, such as cleft lip or palate or neural tube defects. Our goal is to understand the strategies animals apply to epithelial openings. In the long term, our results may be of wider societal benefit as they may accelerate the development of novel therapies for the enhancement of wound healing. Drosophila melanogaster has in the past provided a powerful experimental system for the genetic dissection of developmental processes. It is particularly amenable to in vivo analysis of mechanisms that allow a multi-cellular organism to close epithelial openings caused by wounding or arising as part of the developmental program.

Several developmental processes, such as dorsal closure of the embryo, involve a coordinated series of cellular activities that are very similar to those required for wound healing. Dorsal closure represents the last major morphogenetic movement during embryogenesis, when two opposed epithelial sheets converge toward the midline where they meet, sealing a hole at the dorsal surface of the embryo. Efficient dorsal closure requires the dynamic rearrangement of the cytoskeleton in epithelial cells. DME cells form a leading edge facing towards the dorsal opening, where they accumulate an actomyosin cable. In addition, DME cells extend actin-rich cellular protrusions, such as filopodia and lamellipodia, mediating initial contacting of the opposing DME cells.

At the onset of closure, DME cells display an irregularly distributed network of MTs. During closure, MTs reorganize to form acentrosomal bundles that are aligned along the dorsalventral cell axis. Although the bundles are stable, individual MTs remain highly dynamic, and at the leading edge they grow into cell protrusions.

Genetic screening, biochemical and cell biological approaches have uncovered a large number of structural and signalling molecules required for these closure events. Several studies have highlighted the importance of reorganization of actin-based structures, such as filopodia and lamellipodia, but the function of the microtubule (MT) network is very poorly understood. Our primary goal was the identification of genes required for MT network structure and function during dorsal closure and the in vivo analysis of these genes by determining their exact role in epithelial closure. 
To uncover novel components required for microtubule reorganization and function, we have applied an RNAi-based screening method combined with automated in vivo video microscopy and we identified the short stop (shot) to be essential for the zippering of the dorsal hole. The silencing of shot results in abnormal dorsal closure. In embryos with reduced shot function, the opening is closed completely, but the dynamics of the closure is abnormal. In the shotRNAi embryos, the dorsal opening was abnormally narrow, not the typical wild-type teardrop-shaped dorsal hole. Quantification of closure dynamics revealed that shot function is essential for efficient zippering. Targeted expression of the Shot protein rescued the zippering defect indicating that the phenotype loss of the function of the shot gene. Shot belongs to the conserved family of the spectraplakins, gigantic structural proteins with functional domains binding to actin filaments, microtubules and cell adhesion complexes. These proteins exhibit a characteristic multidomain protein structure, and their transcripts are alternatively spliced to generate a wide diversity of isoforms. In order to understand the role of the individual protein domains of Shot in dorsal closure, we investigated the mutant phenotypes of various shot mutant alleles abolishing distinct Shot activities. In addition, we carried out a detailed structurefunction analysis of Shot using a series of shot transgenes in rescue experiments. Using isoformspecific mutant alleles and genetic rescue experiments with truncated Shot variants, we demonstrate that Shot functions as an actin-microtubule cross-linker in mediating zippering. To study the involvement of shot in MT network organization, we examined MT distribution in shot mutant epithelial cells via immunohistochemical labelling, and performed live imaging of DME cells expressing Tubulin-EGFP. In the cell body of shot ${ }^{5 f 2}$ null mutants, the overall morphology of the MT network appeared slightly disorganized. Very often, sudden bending of MTs was detected. Moreover, MTs frequently protruded at the lateral surface of the epithelial cells. At the leading edge of the mutant DME cells, long and bent MTs protruded from the cell body over the amnioserosa cells, indicating that shot regulates the proper organization of MTs in the cell body and at the leading edge. Time-lapse analysis revealed that the maximum length of the protruding MTs increased, indicating a role played by Shot in regulating MT stability. FRAP assays were applied to analyze the turnover of tubulin, which reflects the dynamic properties of the MTs. MTs in shot mutants are more dynamic, suggesting that Shot affects the MT organization of DME cells by regulating the dynamic properties of MTs. To test Shot's function in MT growth regulation, EB1-EGFP was expressed in $s h o t^{s f 20}$ null mutant epithelial cells. EB1 binds to polymerizing MT plus ends, which enables direct measurement of the dynamic instability parameters by in vivo imaging. In mutant cells, the growth rate of MTs reflected by the speed of EB1 comets increased significantly, supporting the finding that Shot 
regulates MT dynamics. In both wild-type and shot ${ }^{s f 20}$ null mutant embryos, most of the MTs polymerized parallel to the long axis of DME cells, indicating that Shot is not required for the regulation of MT growth direction along the actin filaments.

In order to better understand the role of Shot in MT regulation, we investigated the MT network of epithelial cells in isoform-specific shot mutants, in addition we expressed various truncated versions of Shot in $s h o t^{s / 20}$ null mutant embryos using the en-Gal4 driver which drives the expression of the transgenes in only four-cell-wide stripes of the dorsally migrating epithelial sheets. This experimental design enabled us to compare shot-deficient cells with rescued cells in the same embryo. In summary, we conclude that the MT- binding activity of Shot is required but is not sufficient for MT stabilization and the actin-binding activity of Shot is also required for MT stabilization.

In the leading edge of epithelial cells, Shot regulates protrusion dynamics by promoting filopodia formation. Shot mediated interactions between microtubules and actin filaments facilitate formation of filopodia which promote zippering by initiating contacting of opposing epithelial cells during zipping.

Our work provides insights how mechanisms integrating individual cytoskeletal elements into complex, highly shaped functional patterns contribute to a developmental process at the organism level. 


\section{KÖSZÖNETNYILVÁNÍTÁS}

Szeretném megköszönni Dr. Jankovics Ferenc témavezetőmnek, hogy támogatott a dolgozat megírásában, bevezetett a tudományos módszerek, a tudományos gondolkodás világába. Köszönöm szakmai irányítását, hasznos tanácsait és a dolgozatom alapos és kritikus átnézését.

Köszönettel tartozom Dr. Erdélyi Miklósnak, a Genetikai Intézet igazgatójának, aki lehetővé tette számomra, hogy a Biológus PhD program hallgatója legyek. Ösztönzö támogatásával, tanácsaival, építő kritikáival és türelmével segítette a munkámat.

Külön köszönöm Ugrainé Szathmári Margit aszisztensünknek a segítségét, akinek munkája elképzelhetetlenül sok időt és energiát spórolt meg számomra.

Köszönet illeti továbbá a csoport egykori és jelenlegi tagjait és a szegedi Drosophila közösség valamennyi dolgozóját, hogy a rám bízott feladatokat családias, baráti és nem utólsó sorban jó szakmai légkörben végezhettem.

Végül szeretném megköszönni családomnak, elsősorban férjemnek, Takács Tibornak a támogatását és türelmét.

A PhD dolgozat alapját képező kutatómunka a GINOP-2.3.2.-15-2016-00001 pályázat támogatásával valósult meg. 


\section{IRODALOMJEGYZÉK}

1. Martin, P. and S.M. Parkhurst, Parallels between tissue repair and embryo morphogenesis. Development, 2004. 131(13): p. 3021-34.

2. Mitchell, L.E., et al., Spina bifida. Lancet, 2004. 364(9448): p. 1885-95.

3. Grose, R. and P. Martin, Parallels between wound repair and morphogenesis in the embryo. Semin Cell Dev Biol, 1999. 10(4): p. 395-404.

4. Wood, W., et al., Wound healing recapitulates morphogenesis in Drosophila embryos. Nat Cell Biol, 2002. 4(11): p. 907-12.

5. Jacinto, A., et al., Dynamic actin-based epithelial adhesion and cell matching during Drosophila dorsal closure. Curr Biol, 2000. 10(22): p. 1420-6.

6. Jacinto, A., S. Woolner, and P. Martin, Dynamic analysis of dorsal closure in Drosophila: from genetics to cell biology. Dev Cell, 2002. 3(1): p. 9-19.

7. Jankovics, F. and D. Brunner, Transiently reorganized microtubules are essential for zippering during dorsal closure in Drosophila melanogaster. Dev Cell, 2006. 11(3): p. 375-85.

8. Gates, J., et al., Enabled plays key roles in embryonic epithelial morphogenesis in Drosophila. Development, 2007. 134(11): p. 2027-39.

9. Millard, T.H. and P. Martin, Dynamic analysis of filopodial interactions during the zippering phase of Drosophila dorsal closure. Development, 2008. 135(4): p. 621-6.

10. Eltsov, M., et al., Quantitative analysis of cytoskeletal reorganization during epithelial tissue sealing by large-volume electron tomography. Nat Cell Biol, 2015. 17(5): p. 60514.

11. Chen, X., Bidirectional communication between tissues regulating morphogenesis in a Drosophila model of wound healing, in Department of Molecular Biology and Biochemistry Faculty of Science. 2014.

12. Kiehart, D.P., et al., Multiple forces contribute to cell sheet morphogenesis for dorsal closure in Drosophila. J Cell Biol, 2000. 149(2): p. 471-90.

13. Hutson, M.S., et al., Forces for morphogenesis investigated with laser microsurgery and quantitative modeling. Science, 2003. 300(5616): p. 145-9.

14. Harden, N., Signaling pathways directing the movement and fusion of epithelial sheets: lessons from dorsal closure in Drosophila. Differentiation, 2002. 70(4-5): p. 181-203. 
15. Hayes, P. and J. Solon, Drosophila dorsal closure: An orchestra of forces to zip shut the embryo. Mech Dev, 2017. 144(Pt A): p. 2-10.

16. Akhmanova, A. and M.O. Steinmetz, Tracking the ends: a dynamic protein network controls the fate of microtubule tips. Nat Rev Mol Cell Biol, 2008. 9(4): p. 309-22.

17. B., A., J. A, and L. J, The Self-Assembly and Dynamic Structure of Cytoskeletal Filaments. Molecular Biology of the Cell 2002.

18. Lodish H, B.A., Zipursky SL, et al., Molecular Cell Biology. 4th edition. New York: W. H. Freeman; 2000. Section 19.2, Microtubule Dynamics and Associated Proteins. 2000.

19. Schuyler, S.C. and D. Pellman, Microtubule "plus-end-tracking proteins": The end is just the beginning. Cell, 2001. 105(4): p. 421-4.

20. Hayashi, I. and M. Ikura, Crystal structure of the amino-terminal microtubule-binding domain of end-binding protein 1 (EB1). J Biol Chem, 2003. 278(38): p. 36430-4.

21. Komarova, Y., et al., Mammalian end binding proteins control persistent microtubule growth. J Cell Biol, 2009. 184(5): p. 691-706.

22. Skube, S.B., J.M. Chaverri, and H.V. Goodson, Effect of GFP tags on the localization of EB1 and EB1 fragments in vivo. Cytoskeleton (Hoboken), 2010. 67(1): p. 1-12.

23. Su, L.K. and Y. Qi, Characterization of human MAPRE genes and their proteins. Genomics, 2001. 71(2): p. 142-9.

24. Rogers, S.L., et al., Drosophila EB1 is important for proper assembly, dynamics, and positioning of the mitotic spindle. J Cell Biol, 2002. 158(5): p. 873-84.

25. Tirnauer, J.S., et al., Yeast Bimlp promotes the G1-specific dynamics of microtubules. J Cell Biol, 1999. 145(5): p. 993-1007.

26. Dominguez, R. and K.C. Holmes, Actin structure and function. Annu Rev Biophys, 2011. 40: p. 169-86.

27. Revenu, C., et al., The co-workers of actin filaments: from cell structures to signals. Nat Rev Mol Cell Biol, 2004. 5(8): p. 635-46.

28. Byars, C.L., K.L. Bates, and A. Letsou, The dorsal-open group gene raw is required for restricted DJNK signaling during closure. Development, 1999. 126(21): p. 4913-23.

29. Hou, X.S., E.S. Goldstein, and N. Perrimon, Drosophila Jun relays the Jun aminoterminal kinase signal transduction pathway to the Decapentaplegic signal transduction pathway in regulating epithelial cell sheet movement. Genes Dev, 1997. 11(13): p. 1728-37.

30. Rios-Barrera, L.D. and J.R. Riesgo-Escovar, Regulating cell morphogenesis: the Drosophila Jun N-terminal kinase pathway. Genesis, 2013. 51(3): p. 147-62. 
31. Stronach, B. and N. Perrimon, Activation of the JNK pathway during dorsal closure in Drosophila requires the mixed lineage kinase, slipper. Genes Dev, 2002. 16(3): p. $377-$ 87.

32. Ciapponi, L. and D. Bohmann, An essential function of AP-1 heterodimers in Drosophila development. Mech Dev, 2002. 115(1-2): p. 35-40.

33. Stronach, B., Dissecting JNK signaling, one KKKinase at a time. Dev Dyn, 2005. 232(3): p. 575-84.

34. Zahedi, B., et al., Leading edge-secreted Dpp cooperates with ACK-dependent signaling from the amnioserosa to regulate myosin levels during dorsal closure. Dev Dyn, 2008. 237(10): p. 2936-46.

35. Fernandez, B.G., A.M. Arias, and A. Jacinto, Dpp signalling orchestrates dorsal closure by regulating cell shape changes both in the amnioserosa and in the epidermis. Mech Dev, 2007. 124(11-12): p. 884-97.

36. Noselli, S. and F. Agnes, Roles of the JNK signaling pathway in Drosophila morphogenesis. Curr Opin Genet Dev, 1999. 9(4): p. 466-72.

37. Shimmi, O. and S.J. Newfeld, New insights into extracellular and post-translational regulation of TGF-beta family signalling pathways. J Biochem, 2013. 154(1): p. 11-9.

38. Franke, J.D., R.A. Montague, and D.P. Kiehart, Nonmuscle myosin II generates forces that transmit tension and drive contraction in multiple tissues during dorsal closure. Curr Biol, 2005. 15(24): p. 2208-21.

39. Pickering, K., et al., Par3/Bazooka and phosphoinositides regulate actin protrusion formation during Drosophila dorsal closure and wound healing. Development, 2013. 140(4): p. 800-9.

40. Ridley, A.J., Rho GTPases and cell migration. J Cell Sci, 2001. 114(Pt 15): p. 2713-22.

41. Harden, N., et al., Participation of small GTPases in dorsal closure of the Drosophila embryo: distinct roles for Rho subfamily proteins in epithelial morphogenesis. J Cell Sci, 1999. 112 ( Pt 3): p. 273-84.

42. Magie, C.R., et al., Mutations in the Rhol small GTPase disrupt morphogenesis and segmentation during early Drosophila development. Development, 1999. 126(23): p. 5353-64.

43. Ducuing, A. and S. Vincent, The actin cable is dispensable in directing dorsal closure dynamics but neutralizes mechanical stress to prevent scarring in the Drosophila embryo. Nat Cell Biol, 2016. 18(11): p. 1149-1160. 
44. Hakeda-Suzuki, S., et al., Rac function and regulation during Drosophila development. Nature, 2002. 416(6879): p. 438-42.

45. Harden, N., et al., A dominant inhibitory version of the small GTP-binding protein Rac disrupts cytoskeletal structures and inhibits developmental cell shape changes in Drosophila. Development, 1995. 121(3): p. 903-14.

46. Jefferson, J.J., C.L. Leung, and R.K. Liem, Plakins: goliaths that link cell junctions and the cytoskeleton. Nat Rev Mol Cell Biol, 2004. 5(7): p. 542-53.

47. Karakesisoglou, I., Y. Yang, and E. Fuchs, An epidermal plakin that integrates actin and microtubule networks at cellular junctions. J Cell Biol, 2000. 149(1): p. 195-208.

48. Lee, S., et al., short stop is allelic to kakapo, and encodes rod-like cytoskeletalassociated proteins required for axon extension. J Neurosci, 2000. 20(3): p. 1096-108.

49. Lee, S. and P.A. Kolodziej, Short Stop provides an essential link between F-actin and microtubules during axon extension. Development, 2002. 129(5): p. 1195-204.

50. Sun, D., C.L. Leung, and R.K. Liem, Characterization of the microtubule binding domain of microtubule actin crosslinking factor (MACF): identification of a novel group of microtubule associated proteins. J Cell Sci, 2001. 114(Pt 1): p. 161-172.

51. Brown, N.H., Spectraplakins: the cytoskeleton's Swiss army knife. Cell, 2008. 135(1): p. 16-8.

52. Roper, K., S.L. Gregory, and N.H. Brown, The 'spectraplakins': cytoskeletal giants with characteristics of both spectrin and plakin families. J Cell Sci, 2002. 115(Pt 22): p. 4215-25.

53. Sonnenberg, A. and R.K. Liem, Plakins in development and disease. Exp Cell Res, 2007. 313(10): p. 2189-203.

54. Broderick, M.J. and S.J. Winder, Spectrin, alpha-actinin, and dystrophin. Adv Protein Chem, 2005. 70: p. 203-46.

55. Machnicka, B., et al., Spectrins: a structural platform for stabilization and activation of membrane channels, receptors and transporters. Biochim Biophys Acta, 2014. 1838(2): p. 620-34.

56. Sharaby, Y., et al., Gas2l3 is essential for brain morphogenesis and development. Dev Biol, 2014. 394(2): p. 305-13.

57. Stroud, M.J., et al., GAS2-like proteins mediate communication between microtubules and actin through interactions with end-binding proteins. J Cell Sci, 2014. 127(Pt 12): p. $2672-82$. 
58. Wolter, P., et al., GAS2L3, a target gene of the DREAM complex, is required for proper cytokinesis and genomic stability. J Cell Sci, 2012. 125(Pt 10): p. 2393-406.

59. Huelsmann, S. and N.H. Brown, Spectraplakins. Curr Biol, 2014. 24(8): p. R307-8.

60. Aumailley, M., et al., Molecular basis of inherited skin-blistering disorders, and therapeutic implications. Expert Rev Mol Med, 2006. 8(24): p. 1-21.

61. Edvardson, S., et al., Hereditary sensory autonomic neuropathy caused by a mutation in dystonin. Ann Neurol, 2012. 71(4): p. 569-72.

62. Ferrier, A., J.G. Boyer, and R. Kothary, Cellular and molecular biology of neuronal dystonin. Int Rev Cell Mol Biol, 2013. 300: p. 85-120.

63. Young, K.G. and R. Kothary, Dystonin/Bpag1--a link to what? Cell Motil Cytoskeleton, 2007. 64(12): p. 897-905.

64. Bernier, G., et al., Dystonin expression in the developing nervous system predominates in the neurons that degenerate in dystonia musculorum mutant mice. Mol Cell Neurosci, 1995. 6(6): p. 509-20.

65. Brown, A., et al., The mouse dystonia musculorum gene is a neural isoform of bullous pemphigoid antigen 1. Nat Genet, 1995. 10(3): p. 301-6.

66. Liu, J.J., et al., BPAGln4 is essential for retrograde axonal transport in sensory neurons. J Cell Biol, 2003. 163(2): p. 223-9.

67. Kodama, A., et al., ACF7: an essential integrator of microtubule dynamics. Cell, 2003. 115(3): p. 343-54.

68. Fassett, J.T., et al., Microtubule Actin Cross-linking Factor 1 regulates cardiomyocyte microtubule distribution and adaptation to hemodynamic overload. PLoS One, 2013. 8(9): p. e73887.

69. Goryunov, D., et al., Nervous-tissue-specific elimination of microtubule-actin crosslinking factor la results in multiple developmental defects in the mouse brain. Mol Cell Neurosci, 2010. 44(1): p. 1-14.

70. $\mathrm{Wu}, \mathrm{X}$., et al., Skin stem cells orchestrate directional migration by regulating microtubule-ACF7 connections through GSK3beta. Cell, 2011. 144(3): p. 341-52.

71. Prokop, A., et al., The kakapo mutation affects terminal arborization and central dendritic sprouting of Drosophila motorneurons. J Cell Biol, 1998. 143(5): p. 1283-94.

72. Reuter, J.E., et al., A mosaic genetic screen for genes necessary for Drosophila mushroom body neuronal morphogenesis. Development, 2003. 130(6): p. 1203-13.

73. Prout, M., et al., Autosomal mutations affecting adhesion between wing surfaces in Drosophila melanogaster. Genetics, 1997. 146(1): p. 275-85. 
74. Roper, K. and N.H. Brown, Maintaining epithelial integrity: a function for gigantic spectraplakin isoforms in adherens junctions. J Cell Biol, 2003. 162(7): p. 1305-15.

75. Walsh, E.P. and N.H. Brown, A screen to identify Drosophila genes required for integrin-mediated adhesion. Genetics, 1998. 150(2): p. 791-805.

76. Young, K.G., M. Pool, and R. Kothary, Bpag1 localization to actin filaments and to the nucleus is regulated by its N-terminus. J Cell Sci, 2003. 116(Pt 22): p. 4543-55.

77. Hopkinson, S.B. and J.C. Jones, The $N$ terminus of the transmembrane protein BP180 interacts with the N-terminal domain of BP230, thereby mediating keratin cytoskeleton anchorage to the cell surface at the site of the hemidesmosome. Mol Biol Cell, 2000. 11(1): p. 277-86.

78. Letunic, I., et al., Recent improvements to the SMART domain-based sequence annotation resource. Nucleic Acids Res, 2002. 30(1): p. 242-4.

79. Leung, C.L., K.J. Green, and R.K. Liem, Plakins: a family of versatile cytolinker proteins. Trends Cell Biol, 2002. 12(1): p. 37-45.

80. Suozzi, K.C., X. Wu, and E. Fuchs, Spectraplakins: master orchestrators of cytoskeletal dynamics. J Cell Biol, 2012. 197(4): p. 465-75.

81. Burgoyne, R.D., et al., Neuronal Ca2+-sensor proteins: multitalented regulators of neuronal function. Trends Neurosci, 2004. 27(4): p. 203-9.

82. Goriounov, D., C.L. Leung, and R.K. Liem, Protein products of human Gas2-related genes on chromosomes 17 and 22 (hGAR17 and hGAR22) associate with both microfilaments and microtubules. J Cell Sci, 2003. 116(Pt 6): p. 1045-58.

83. Slep, K.C., et al., Structural determinants for EB1-mediated recruitment of APC and spectraplakins to the microtubule plus end. J Cell Biol, 2005. 168(4): p. 587-98.

84. Hahn, I., et al., Functional and Genetic Analysis of Spectraplakins in Drosophila. Methods Enzymol, 2016. 569: p. 373-405.

85. Morin, X., et al., A protein trap strategy to detect GFP-tagged proteins expressed from their endogenous loci in Drosophila. Proc Natl Acad Sci U S A, 2001. 98(26): p. 150505.

86. Fulga, T.A. and P. Rorth, Invasive cell migration is initiated by guided growth of long cellular extensions. Nat Cell Biol, 2002. 4(9): p. 715-9.

87. Inoue, Y.H., et al., Mutations in orbit/mast reveal that the central spindle is comprised of two microtubule populations, those that initiate cleavage and those that propagate furrow ingression. J Cell Biol, 2004. 166(1): p. 49-60. 
88. Alves-Silva, J., et al., Spectraplakins promote microtubule-mediated axonal growth by functioning as structural microtubule-associated proteins and EB1-dependent +TIPS (tip interacting proteins). J Neurosci, 2012. 32(27): p. 9143-58.

89. Subramanian, A., et al., Shortstop recruits EB1/APC1 and promotes microtubule assembly at the muscle-tendon junction. Curr Biol, 2003. 13(13): p. 1086-95.

90. Takacs, Z., et al., The spectraplakin Short stop is an essential microtubule regulator involved in epithelial closure in Drosophila. J Cell Sci, 2017. 130(4): p. 712-724.

91. Bottenberg, W., Neuronal differentiation and epithelial integrity: The role of Drosophila Short Stop. Mainz: Johannes Gutenberg University., 2006.

92. Bottenberg, W., et al., Context-specific requirements of functional domains of the Spectraplakin Short stop in vivo. Mech Dev, 2009. 126(7): p. 489-502.

93. Jankovics, F., et al., A functional genomic screen combined with time-lapse microscopy uncovers a novel set of genes involved in dorsal closure of Drosophila embryos. PLoS One, 2011. 6(7): p. e22229.

94. Zeitlinger, J. and D. Bohmann, Thorax closure in Drosophila: involvement of Fos and the JNK pathway. Development, 1999. 126(17): p. 3947-56.

95. Ren, X., et al., Genome editing in Drosophila melanogaster: from basic genome engineering to the multipurpose CRISPR-Cas9 system. Sci China Life Sci, 2017. 60(5): p. 476-489.

96. Mali, P., et al., RNA-guided human genome engineering via Cas9. Science, 2013. 339(6121): p. 823-6.

97. Bassett, A.R. and J.L. Liu, CRISPR/Cas9 and genome editing in Drosophila. J Genet Genomics, 2014. 41(1): p. 7-19.

98. Lee, J., et al., shot regulates the microtubule reorganization required for localization of axis-determining mRNAs during oogenesis. FEBS Lett, 2016. 590(4): p. 431-44.

99. Sanchez-Soriano, N., et al., Drosophila growth cones: a genetically tractable platform for the analysis of axonal growth dynamics. Dev Neurobiol, 2010. 70(1): p. 58-71.

100. Asthana, J., et al., Inhibition of HDAC6 deacetylase activity increases its binding with microtubules and suppresses microtubule dynamic instability in MCF-7 cells. J Biol Chem, 2013. 288(31): p. 22516-26.

101. Matov, A., et al., Analysis of microtubule dynamic instability using a plus-end growth marker. Nat Methods, 2010. 7(9): p. 761-8. 
102. Matsuyama, A., et al., In vivo destabilization of dynamic microtubules by HDAC6mediated deacetylation. Embo j, 2002. 21(24): p. 6820-31.

103. Tran, A.D., et al., HDAC6 deacetylation of tubulin modulates dynamics of cellular adhesions. J Cell Sci, 2007. 120(Pt 8): p. 1469-79.

104. Webster, D.R. and G.G. Borisy, Microtubules are acetylated in domains that turn over slowly. J Cell Sci, 1989. 92 ( Pt 1): p. 57-65.

105. Zilberman, Y., et al., Regulation of microtubule dynamics by inhibition of the tubulin deacetylase HDAC6. J Cell Sci, 2009. 122(Pt 19): p. 3531-41.

106. Preciado Lopez, M., et al., Actin-microtubule coordination at growing microtubule ends. Nat Commun, 2014. 5: p. 4778.

107. Akhmanova, A. and M.O. Steinmetz, Control of microtubule organization and dynamics: two ends in the limelight. Nat Rev Mol Cell Biol, 2015. 16(12): p. 711-26.

108. Chen, Y., M.M. Rolls, and W.O. Hancock, An EB1-kinesin complex is sufficient to steer microtubule growth in vitro. Curr Biol, 2014. 24(3): p. 316-21.

109. Doodhi, H., et al., Mechanical and geometrical constraints control kinesin-based microtubule guidance. Curr Biol, 2014. 24(3): p. 322-8.

110. Mattie, F.J., et al., Directed microtubule growth, +TIPs, and kinesin-2 are required for uniform microtubule polarity in dendrites. Curr Biol, 2010. 20(24): p. 2169-77.

111. Nishimura, Y., et al., Automated screening of microtubule growth dynamics identifies MARK2 as a regulator of leading edge microtubules downstream of Rac1 in migrating cells. PLoS One, 2012. 7(7): p. e41413.

112. Applewhite, D.A., et al., The spectraplakin Short stop is an actin-microtubule crosslinker that contributes to organization of the microtubule network. Mol Biol Cell, 2010. 21(10): p. 1714-24.

113. Sanchez-Soriano, N., et al., Mouse ACF7 and drosophila short stop modulate filopodia formation and microtubule organisation during neuronal growth. J Cell Sci, 2009. 122(Pt 14): p. 2534-42.

114. Wu, X., A. Kodama, and E. Fuchs, ACF7 regulates cytoskeletal-focal adhesion dynamics and migration and has ATPase activity. Cell, 2008. 135(1): p. 137-48.

115. Applewhite, D.A., et al., The actin-microtubule cross-linking activity of Drosophila Short stop is regulated by intramolecular inhibition. Mol Biol Cell, 2013. 24(18): p. 2885-93. 
116. Gierke, S. and T. Wittmann, EB1-recruited microtubule +TIP complexes coordinate protrusion dynamics during 3D epithelial remodeling. Curr Biol, 2012. 22(9): p. 75362.

117. Margaron, Y., N. Fradet, and J.F. Cote, ELMO recruits actin cross-linking family 7 (ACF7) at the cell membrane for microtubule capture and stabilization of cellular protrusions. J Biol Chem, 2013. 288(2): p. 1184-99.

118. Woolner, S., A. Jacinto, and P. Martin, The small GTPase Rac plays multiple roles in epithelial sheet fusion--dynamic studies of Drosophila dorsal closure. Dev Biol, 2005. 282(1): p. 163-73.

119. Girdler, G.C., et al., The Gas2 family protein Pigs is a microtubule +TIP that affects cytoskeleton organisation. J Cell Sci, 2016. 129(1): p. 121-34. 


\section{SAJÁT KÖZLEMÉNYEK LISTÁJA}

MTMT azonosító: 10069249

Összesített IF: 10,164

\section{A doktori eljárás alapiát képező 2 db közlemény}

The Spectraplakin Short stop is an essential microtubule regulator involved in epithelial closure in Drosophila.

J Cell Sci, 2017. 130 (4): p. 712-724.

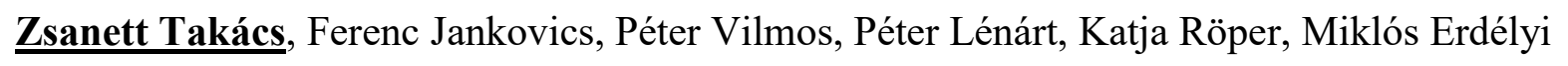

Drosophila small ovary gene is required for transposon silencing and heterochromatin organization, and ensures germline stem cell maintenance and differentiation.

Development, 2018 Dec 4;145(23).

Ferenc Jankovics, Melinda Bence, Rita Sinka, Anikó Faragó, László Bodai, Aladár PettkóSzandtner, Karam Ibrahim, Zsanett Takács, Alexandra Brigitta Szarka-Kovács, Miklós Erdélyi

\section{Referált folyóiratban megjelent közlemények}

The Spectraplakin Short stop is an essential microtubule regulator involved in epithelial closure in Drosophila.

J Cell Sci, 2017. 130 (4): p. 712-724.

Zsanett Takács, Ferenc Jankovics, Péter Vilmos, Péter Lénárt, Katja Röper, Miklós Erdélyi

\section{IF: $\mathbf{4 . 4 0 1}$}

Drosophila small ovary gene is required for transposon silencing and heterochromatin organization, and ensures germline stem cell maintenance and differentiation.

Development, 2018 Dec 4;145(23).

Ferenc Jankovics, Melinda Bence, Rita Sinka, Anikó Faragó, László Bodai, Aladár PettkóSzandtner, Karam Ibrahim, Zsanett Takács, Alexandra Brigitta Szarka-Kovács, Miklós Erdélyi

IF: $\mathbf{5 . 7 6 3}$ 


\section{Egyéb szakmai anyagok}

Angol nyelvű konferencia előadás:

Analysis of the Drosophila Spectraplakin function during epithelial closure processes

Zsanett Lakatos, Ferenc Jankovics, Miklós Erdélyi

Conference for doctoral students in biology, Szeged 2016

Acta Biol Szeged, Vol:60, issue 1

Magyar nyelvü konferencia előadás:

A háti záródásban szerepet jatszó mikrotubulus regulátorok azonosítása és in vivo vizsgálata ecetmuslicában

Lakatos Zsanett, Jankovics Ferenc, Erdélyi Miklós

Tavaszi Szél konferencia, Debrecen, 2014

$\underline{\text { Poszter elöadás: }}$

Identification and in vivo analysis of genes required for microtubule function in epithelial closure processes

Zsanett Lakatos, Ferenc Jankovics, Miklós Erdélyi

Hungarian Molecular Life Sciences, Siófok, 2013

Identification and characterisation of genes involved in embryonic dorsal closure in drosophila melanogaster

Zsanett Lakatos, Ferenc Jankovics, Miklós Erdélyi

Straub Days, Szeged, 2013

The short stop (shot) gene is required for efficient epithelial closure in drosophila melanogaster

Zsanett Lakatos, Ferenc Jankovics, Miklós Erdélyi

Hungarian Molecular Life Sciences, Eger, 2015 